\title{
STT - Um Sistema para Telemetria e Telecomando de Aeronaves do Projeto ARARA
}

\author{
Rômulo Eugênio Ribeiro
}

Orientador: Prof. Dr. Onofre Trindade Junior

Dissertação apresentada ao Instituto de Ciências Matemáticas e de Computação - ICMC-USP, como parte dos requisitos para obtenção do título de Mestre em Ciências - Área: Ciências de Computação e Matemática Computacional.

\footnotetext{
USP - São Carlos

Maio de 2000
}

* Trabalho realizado com o apoio do CNPq. 


\section{Agradecimentos}

Ufa!!! Terminou... Gostaria de agradecer ao Onofre por me dar a oportunidade do mestrado. Uma pessoa cheia de virtudes e teimosa, a qual me recebeu com os braços abertos, hora me tratando como amigo, hora como filho e sempre me ensinando uma lição de vida.

Agradeço também ao meu pai e minha mãe que sempre me apoiaram em todos os momentos desta longa jornada chamada vida. Agradeço à Sandra que me incentivou neste mestrado e sem ela nada disso seria possível.

Agradeço ao Maxweel, uma pessoa cheia de virtudes a qual jamais pensei encontrar. Uma pessoa que me ensinou novos valores de vida. Espero sempre ter sua amizade e o seu respeito. Gostaria de manifestar por escrito minhas desculpas por algumas vezes ter sido intolerante com ele.

Gostaria de agradecer ao Kleber, a Luciana, ao Luciano, ao Cereal, ao Marinho, ao Fernando, ao AlexK, ao Mário, ao André e a todos do LCAD velho, que de uma forma ou de outra contribuíram para este trabalho.

Agradeço em especial a Mara que me suportou e pelos momentos que tivemos aqui em São Carlos.

Com certeza o mestrado foi uma batalha, mas foram os melhores dois anos da minha vida. Agradeço a Deus por sua misericórdia que me conduziu até aqui por sua mão. 
Aos meus pais e em memória do meu avô que faleceu este ano 


\section{Resumo}

Os veículos aéreos não tripulados (UAVs - Unmanned Aerial Vehicles), têm desempenhado um papel importante em diversas aplicações. Os UAVs podem chegar a lugares de difícil acesso, como encostas de montanhas e vales. Com a miniaturização dos componentes eletrônicos e o com aumento do poder de processamento dos computadores, ampliou-se o campo de aplicações dos UAVs. Estes sistemas de baixo custo podem realizar tarefas normalmente executadas por aviões tripulados.

O Projeto ARARA - Aeronaves de Reconhecimento Assistidas por Rádio e Autônomas (Autonomous and Radio-Assisted Reconnaissance Aircraft), está centrado no uso de aeromodelos rádio-controlados para aquisição de dados. Seu principal objetivo está na substituição das aeronaves convencionais usadas na obtenção das fotografias aéreas. A aeronave do ARARA possui baixo custo de manutenção e não requer uma pessoa especializada para sua operação. Embora algumas aeronaves do ARARA foram especificamente projetadas para aquisição de dados, todos os componentes estão disponíveis comercialmente, reduzindo o seu custo e facilitando a sua manutenção.

Este trabalho apresenta o STT (Sistema de Telemetria e Telecomando), como parte do Projeto ARARA. O STT permite operar a aeronave do ARARA além do alcance visual do piloto. As imagens de vídeo e os dados dos instrumentos são transmitidos da aeronave para a estação de base em tempo real. A interface gráfica do STT apresenta o vídeo sobreposto por um painel de instrumentos, similar aos simuladores de vôo tornando a sua operação muito intuitiva.

Os resultados obtidos da simulação do uso do STT confirmaram sua aplicabilidade para o Projeto ARARA. Os teste operacionais de campo dependem do hardware do sistema que está em desenvolvimento. 


\section{Abstract}

The UAVs (Unmanned Aerial Vehicles) have performed an important role in several applications. UAVs can arrive to places of difficult access, such as hillsides and valleys. With the miniaturization of electronic components and the increase of computer processing power, UAVs have widened their application range. Low cost systems can complete tasks normally done by manned aircraft.

The ARARA Project (Autonomous and Radio-Assisted Reconnaissance Aircraft), is centered on the concept of using radio-controlled (R/C) aircraft for data acquisition. Its main objective is to replace conventional aircraft used for aerial photography. An ARARA aircraft has a much lower maintenance cost and does not require specialized personnel for its operation. Although some of the ARARA aircraft were custom designed for its data acquisition role, all of them use off-the-shelf components whenever possible to reduce costs and for the ease of development and maintenance.

This work presents the STT (Telemetry and Telecommand System), part of the ARARA project. The STT allows ARARA aircraft to be operated beyond the visual range of the pilot. Real time video and instrumentation data are broadcasted from the aircraft to a ground station. The graphic interface of STT presents the video superimposed by an instrument panel, similar to a flight simulator program, making its operation very intuitive.

Results obtained from the simulation of use of the STT have confirmed its applicability to the ARARA project. Operational and field tests depend on the hardware currently under development. 


\section{Sumário}

1 Introdução

1.1 Aspectos Gerais..................................................................................... 1

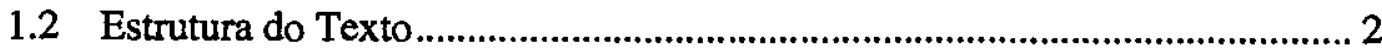

2 Aeronaves não Tripuladas - O Estado da Arte ............................................ 4

2.1 Considerações Iniciais.............................................................................. 4

2.2 Definições e Escopo do Trabalho …………………................................... 4

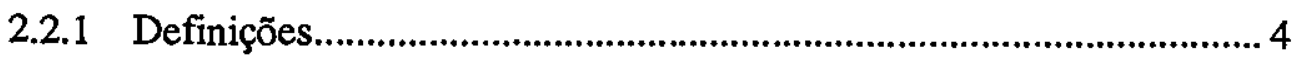

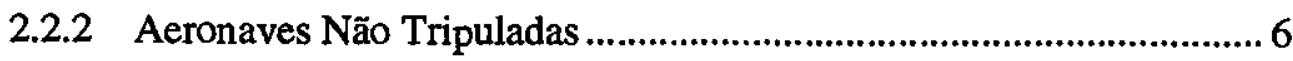

2.3 Elementos Básicos de Aeronaves............................................................ 9

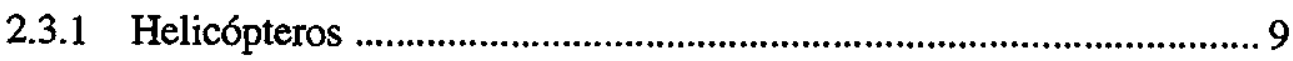

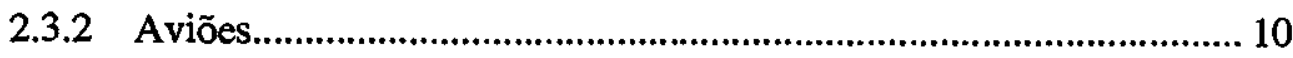

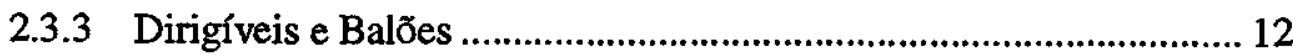

2.4 Instrumentação e Equipamentos Utilizados em UAVs................................. 13

2.4.1 Instrumentação de Bordo ............................................................... 13

2.4.2 Conjuntos Moto-propulsores......................................................... 15

2.4.3 Equipamentos de Rádio-Controle ................................................. 17

2.4.4 Enlaces de Dados via Rádio ............................................................ 18

2.4.5 Técnicas e Protocolos para a Transmissão de Dados .......................... 20

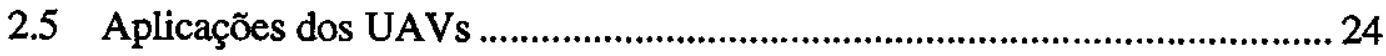

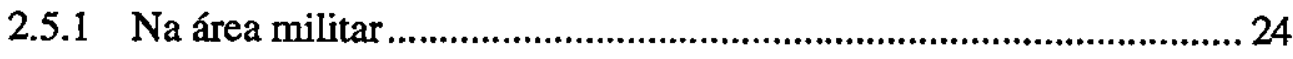

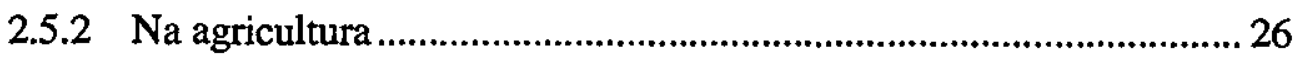

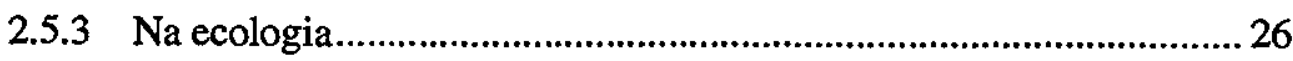

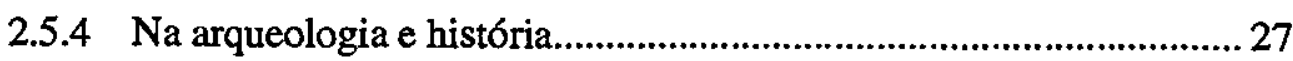

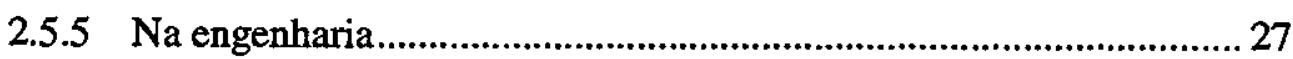

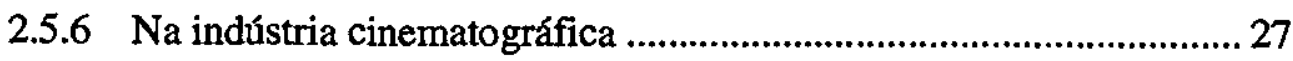

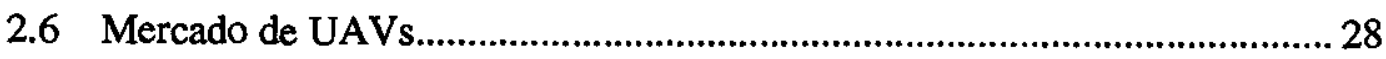

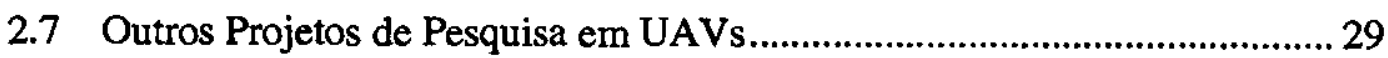

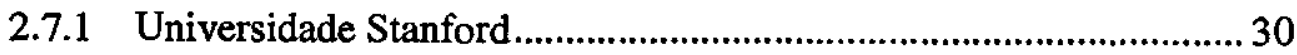

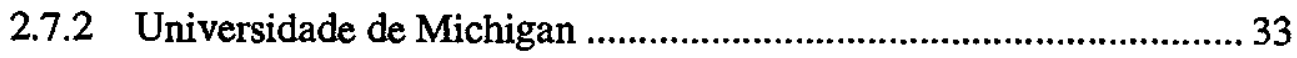

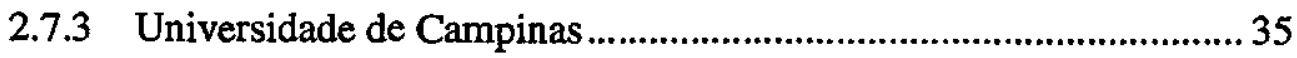

2.7.4 Instituto de Tecnologia Rose-Hulman............................................. 38

2.7.5 Universidade Southern California .................................................... 40

2.7.6 Space Grant College ..................................................................... 42 
2.7.7 Massachusetts Institute of Technology ....................................... 43

2.7.8 Australian Bureau of Meteorology................................................. 45

2.7.9 Universidade Sydney................................................................ 47

2.7.10 Swiss Federal Institute of Technology ....................................... 48

2.8 Considerações sobre os Projetos de Pesquisa Revistos............................... 50

2.9 Considerações Finais.............................................................................. 51

$3 \quad$ Análise de Requisitos do Sistema...................................................... 53

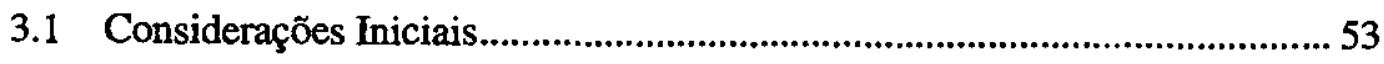

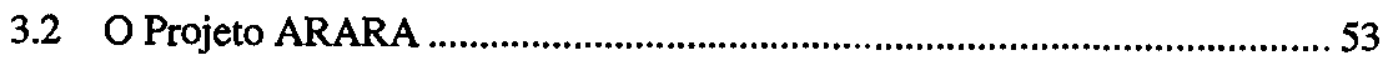

3.3 Hardware do Sistema ........................................................................ 55

3.3.1 Requisitos Funcionais de Hardware ............................................... 56

3.3.2 Requisitos não Funcionais de Hardware ..........................................5.57

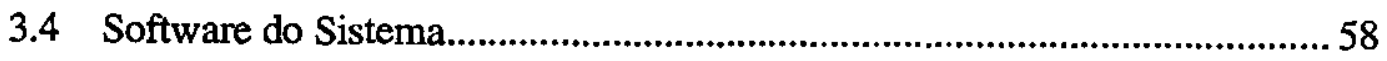

3.4.1 Requisitos Funcionais de Software ................................................ 58

3.4.2 Requisitos Não Funcionais de Software.........................................62 62

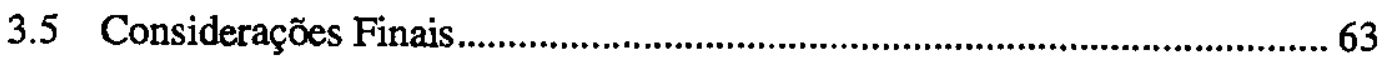

4 Especificação e Projeto do Sistema .......................................................... 64

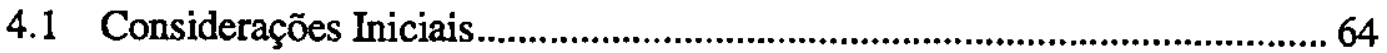

4.2 Especificação e Projeto Preliminar de Hardware .......................................... 64

4.3 Notação estendida de Ward e Mellor .........................................................6.6. 68

4.4 Lista de Eventos do Sistema ...................................................................6 69

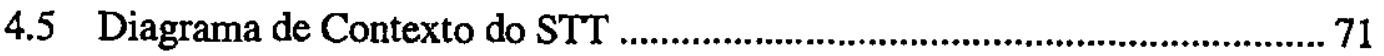

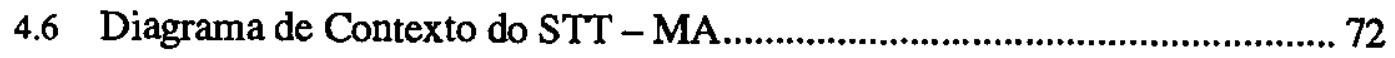

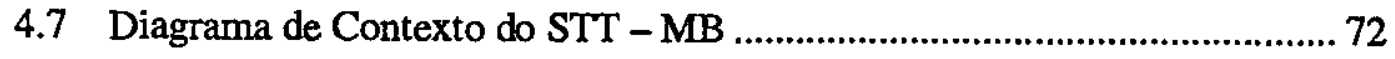

4.8 Diagrama de Fluxo de Dados - Nívell (STT - MA) ................................. 73

4.9 Diagrama de Fluxo de Dados - Nível 1 (STT - MB) ................................. 74

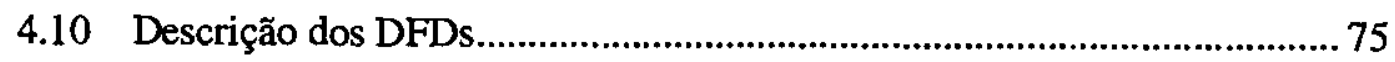

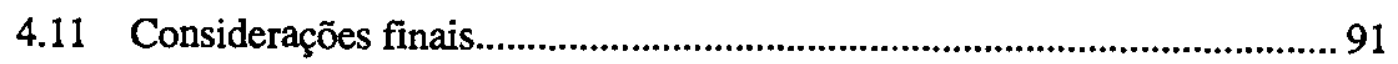

5 Projeto e Implementação do STT ................................................. 92

5.1 Considerações Iniciais........................................................................... 92

Implementação de Software ................................................................... 92

5.2.1 Arquitetura de Implementação do STT - MB ................................. 93

5.2.2 Descrição dos Objetos do STT - MB........................................... 95

5.2.3 Arquitetura de Implementação do STT - MA ............................. 100 
5.3 Validação e Teste do STT ...................................................................... 102

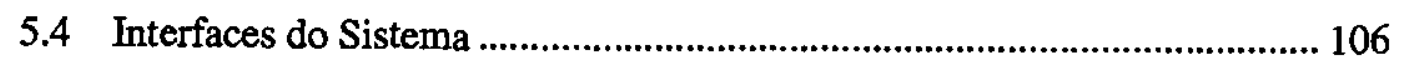

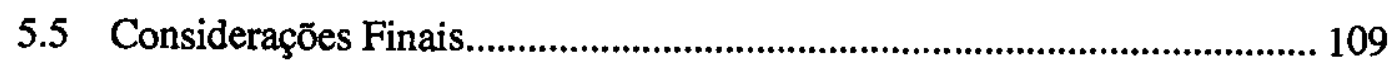

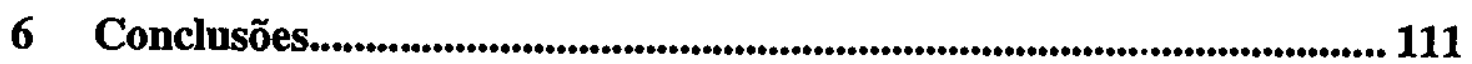

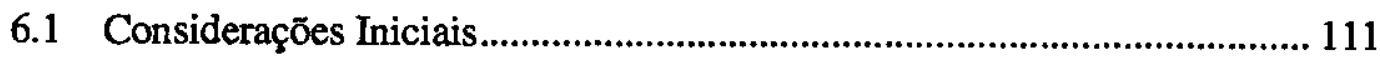

6.2 Contribuições do Trabalho..................................................................... 111

6.3 Sugestões para Trabalhos Futuros e Continuidade da Pesquisa.................. 112

7 Referências Bibliográficas.............................................................................. 114

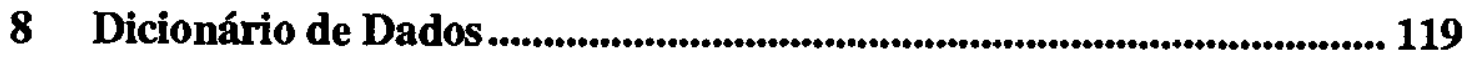

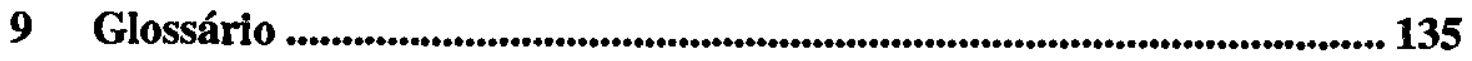




\section{Lista de Figuras}

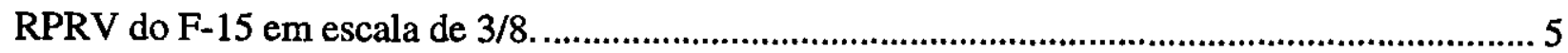

Exemplos de duas maneiras de decolagem de UAVs.............................................................. 7

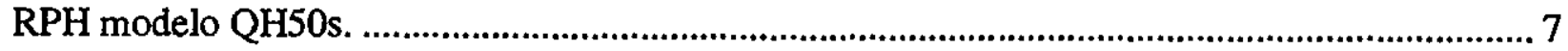

Bússola giroscópica e indicador de horizonte artificial. ........................................................... 14

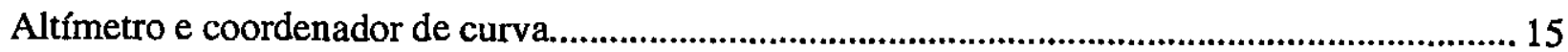

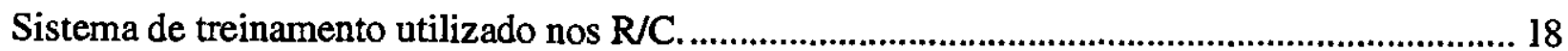

O espectro eletromagnético e a maneira como ele é usado na comunicação................................. 20

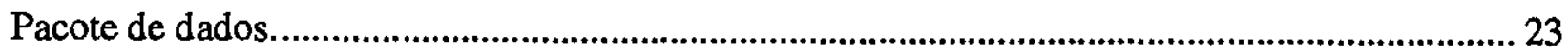

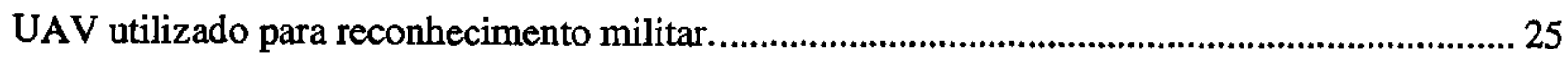

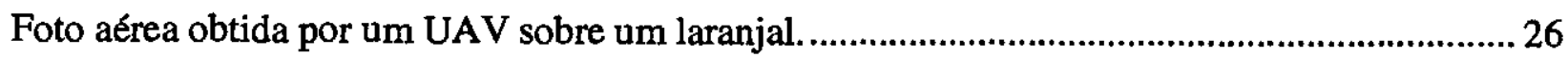

Foto obtida por um UAV para observar o crescimento dos cães da pradaria.............................. 27

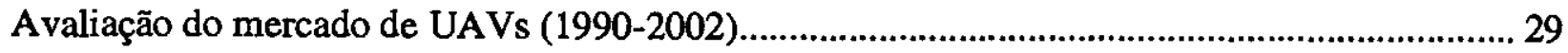

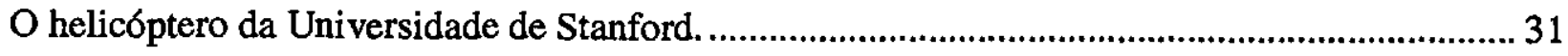

Diagrama de bloco de funcionamento do UAV de Stanford. .......................................................... 32

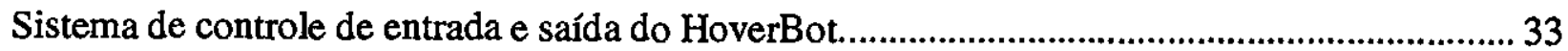

$O$ avião utilizado no projeto da Universidade de Michigan. ........................................................... 35

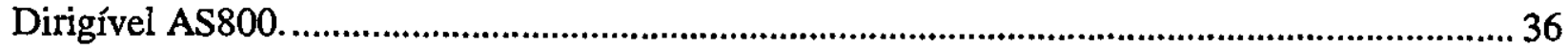

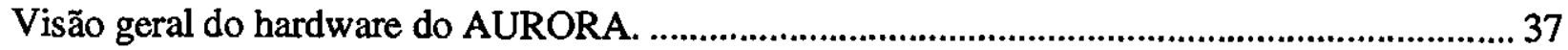

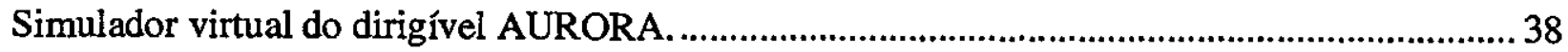

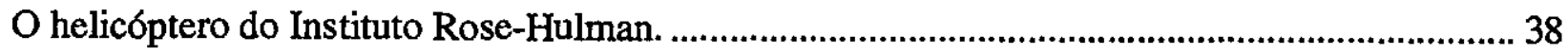

Diagrama de bloco do funcionamento do projeto Rose-Hulman ................................................ 40

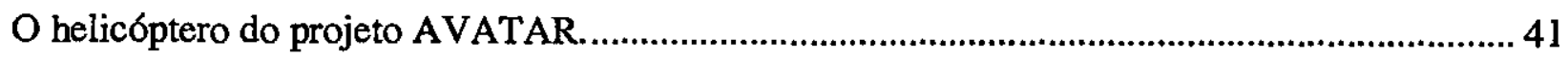

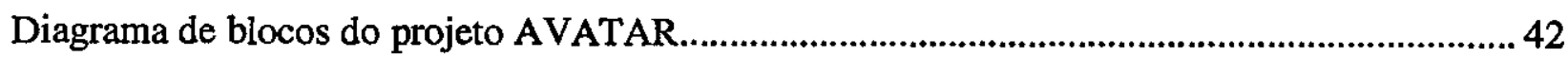

O balão e ao lado o motor e o computador do projeto AIM. .......................................................... 42

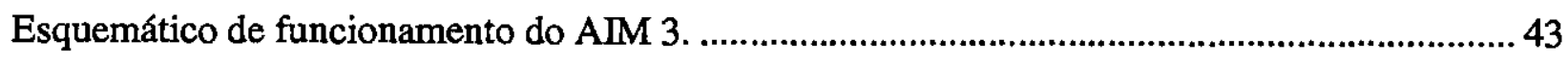

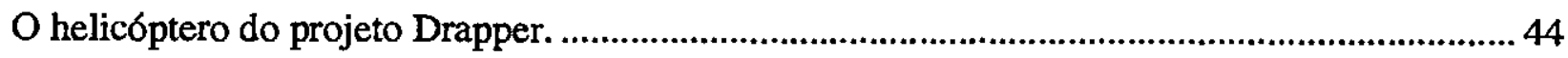

Diagrama de bloco do funcionamento do projeto de MIT........................................................... 45

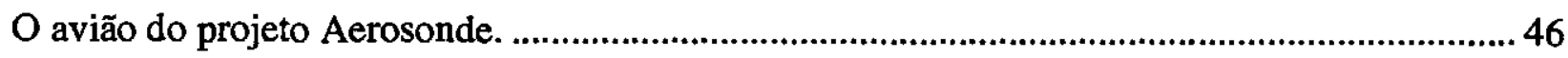

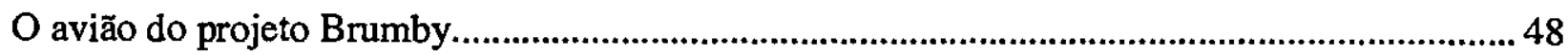


O helicóptero e ao lado a caixa de navegação do projeto da Universidade Zurich. . 49

Interface do HORLA. 49

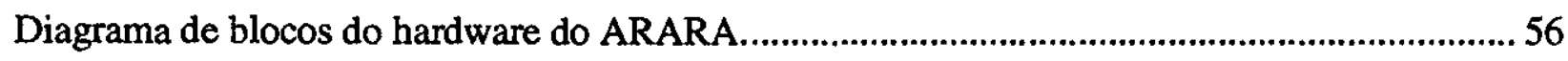

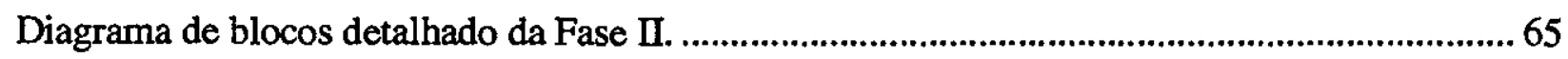

Notação de análise estruturada estendida para sistemas de tempo real. .....................................69

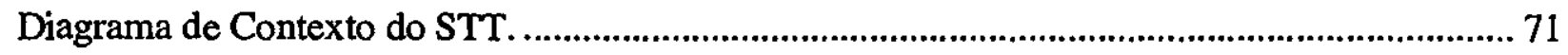

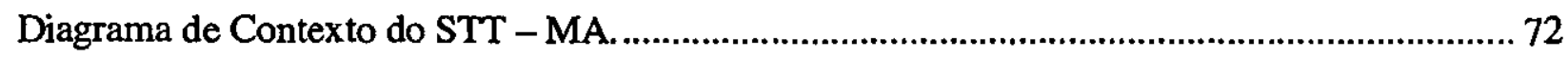

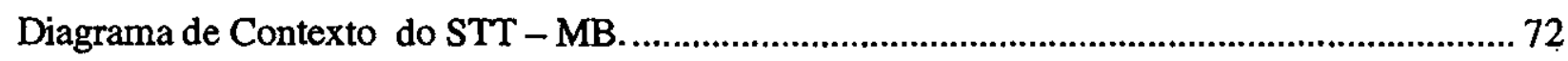

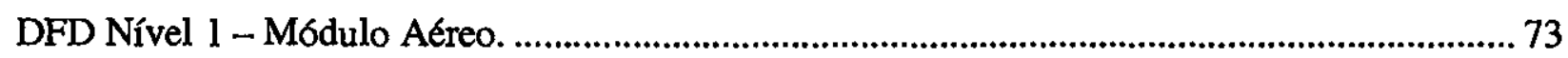

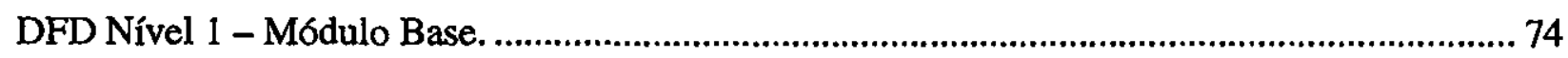

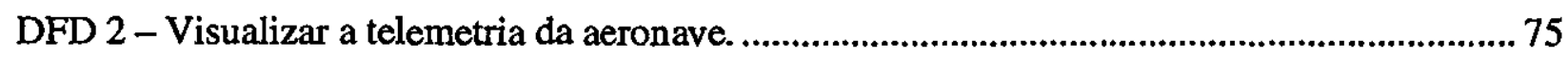

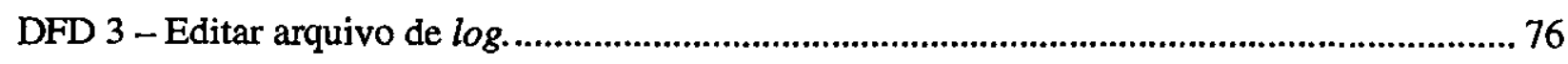

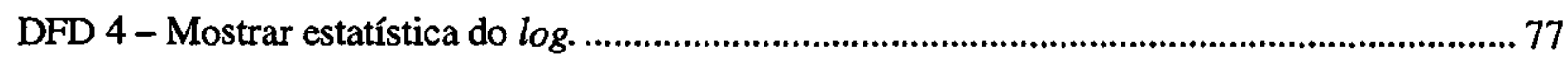

DFD 5 - Visualizar as imagens da câmera fotografica....................................................... 78

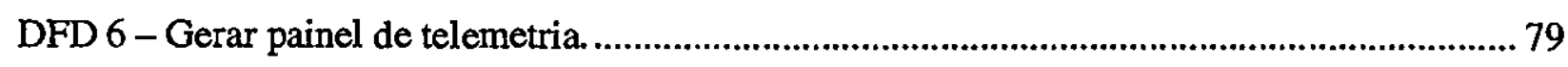

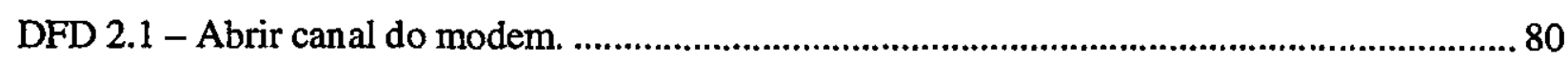

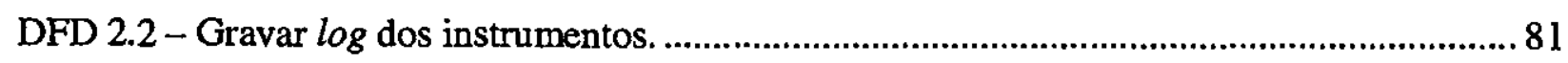

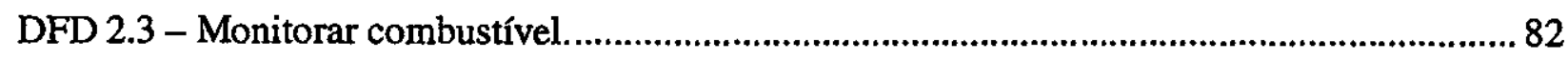

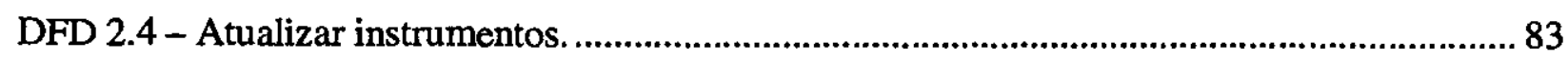

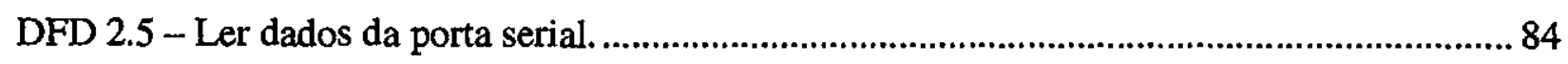

DFD 2.6 - Verificar a distância da Estação Base. ..................................................................... 86

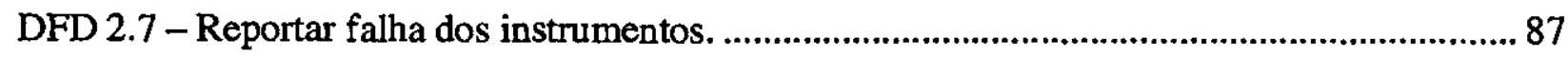

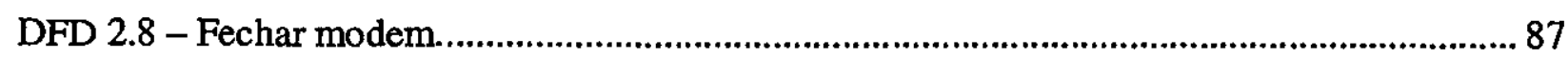

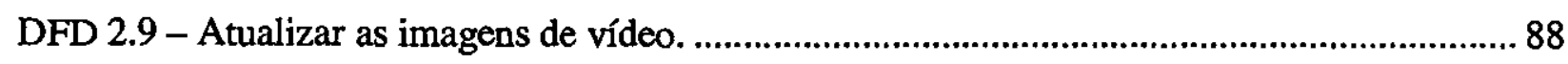

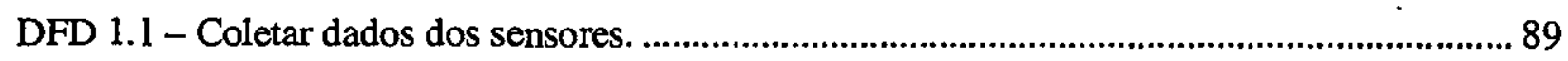

DFD 1.2 - Transmitir dados para a porta serial..................................................................... 90

DFD 1.3 - Realizar autoteste nos sensores................................................................... 91

Modelo de implementação para o STT - MB. .......................................................................... 94

Diagrama dos objetos do sistema do STT - MB. ....................................................................95

Modelo de implementação do STT - MA. ............................................................................... 100

Diagrama da organização dos threads no módulo aéreo. ...................................................... 101

Esquema de montagem dos computadores para teste. ........................................................... 103

Diagrama de transição de estado das interfaces de tela de vídeo. .............................................. 106

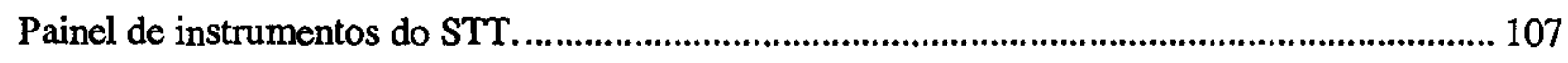

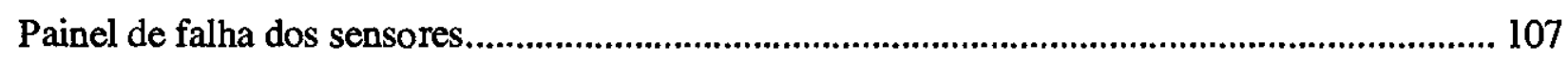

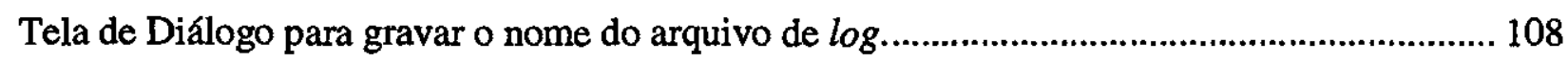


Tela do $\log$ da telemetria. 108

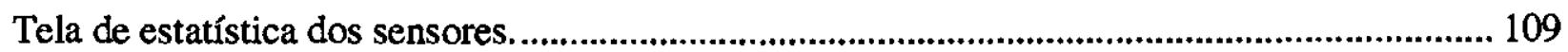

Tela que visualiza as imagens BMP e JPEG. 109 


\section{Lista de Tabelas}

Descrição dos dados contidos no protocolo de enlace de dados................................................ 23

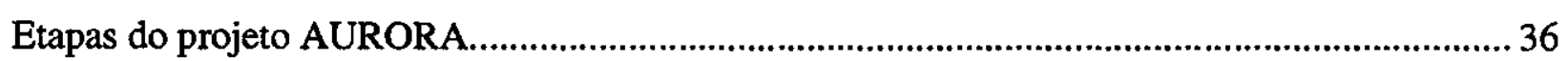

Instrumentação a bordo dos projetos UAV revistos. ............................................................... 51 


\section{Capítulo 1}

Introdução

\subsection{Aspectos Gerais}

Nos últimos anos, os veículos aéreos não tripulados (UAV - Unmanned Aerial Vehicle), têm desempenhado um papel importante em diversas aplicações.

Com a miniaturização dos componentes eletrônicos e o aumento do poder de processamento dos computadores, tornou-se possível à utilização de UAVs em diversas áreas. Projetos de baixo custo podem realizar tarefas até então possíveis somente com a utilização de aeronaves tripuladas. Os UAVs atuais podem chegar a lugares de difícil acesso, como encostas de montanhas e vales, desenvolver velocidades muito altas e ficar suspensos no ar (no caso de helicópteros), para o monitorar um incêndio sem colocar a vida de pilotos em risco.

No desenvolvimento da tecnologia de aviões, os UAVs têm sido utilizados como ferramentas para proporcionar baixo custo nos testes de novos conceitos aerodinâmicos.

$\mathrm{Na}$ área militar, os UAVs são utilizados em missões de reconhecimento e prática de tiro ao alvo, sendo comumente projetados para reutilização, diferentemente dos mísseis que são utilizados uma única vez. Embora os UAVs apresentem um custo relativamente pequeno, em aplicações militares um projeto de UAV pode facilmente chegar à casa de dezenas ou até mesmo centenas de milhares de dólares.

A fotografia aérea e a coleta de dados para monitorar uma área ambiental têm feito uso intensivo de UAVs e se beneficiado da miniaturização do GPS (Global Positioning System), câmeras de vídeo, câmeras fotográficas digitais, equipamentos de rádio e sensores atmosféricos. 
$\mathrm{Na}$ agricultura, a fotografia aérea tem sido usada como uma ferramenta suplementar na identificação de problemas, como pragas causadas por insetos, fungos e elementos atmosféricos.

O Projeto ARARA - Aeronaves de Reconhecimento Assistidas por Rádio e Autônomas (Autonomous and Radio-Assisted Reconnaissance Aircraft) - desenvolvido no LCAD (Laboratório de Computação de Alto Desempenho), departamento de Ciências de Computação e Estatística da USP, campus São Carlos, está centrado no uso de aeronaves em escala reduzida para monitorização. O seu principal objetivo é a substituiçăo das aeronaves convencionais usadas na obtenção de fotografias aéreas utilizadas para monitorar plantações e áreas sujeitas a problemas ambientais.

O objetivo deste trabalho é dar continuidade ao Projeto ARARA, iniciado por Șouza [SOU99] em sua dissertação de mestrado. Souza discutiu a implementação de UAVs para o sensoriamento remoto na agricultura. Foi construído um UAV baseado em aeromodelo convencional para obtenção de fotos aéreas, equipado com uma câmera digital e um microcontrolador que dispara a câmera com um sinal de rádio enviado pelo piloto em solo.

Este trabalho visa a implementação do STT (Sistema de Telemetria e Telecomando) para o Projeto ARARA. Com este sistema, é possível a realização de vôos sem visada direta da aeronave, utilizando-se os dados da instrumentação e câmeras de vídeo a bordo da aeronave e um computador utilizado para monitorar em solo. Uma interface semelhante ao Flight Simulator da Microsoft foi desenvolvida para a visualização dos dados dos sensores e das imagens transmitidas pela aeronave.

\subsection{Estrutura do Texto}

Este texto encontra-se dividido em seis capítulos. No segundo capítulo, são apresentados os conceitos básicos sobre UAVs, bem como uma revisão sobre os componentes e equipamentos necessários para a sua implementação. São investigados os tipos de aeronaves, os equipamentos de controle e as técnicas de comunicação de dados utilizando-se redes ponto a ponto. É apresentada uma avaliação do mercado para sistemas UAVs e o seu potencial de aplicação. Também são revistos os principais projetos em andamento em outras universidades.

No terceiro capítulo, é apresentada uma análise de requisitos de hardware e software detalhando os principais componentes necessários para a implementação do projeto. No quarto capítulo, são apresentados a especificação e o projeto do sistema. No quinto capítulo, são 
apresentados os detalhes da implementação do sistema, teste de validação e as telas de interface do sistema. Finalmente, no sexto capítulo, são apresentadas as conclusões finais e sugestões para trabalhos futuros.

Um glossário com palavras cujo sentido é de uso específico nas áreas envolvidas encontra-se no final deste trabalho. 


\section{Capítulo 2}

\section{Aeronaves não Tripuladas - O Estado da Arte}

\subsection{Considerações Iniciais}

Este capítulo tem como objetivo apresentar os diversos tópicos relacionados no desenvolvimento deste trabalho. Na seção 2.2, é definido o conceito de UAV e diversos outros conceitos relacionados. Na seção 2.3, são revistos os tipos de aeronaves mais usadas em um sistema UAV, sendo comentadas as características de cada tipo. Na seção 2.4 , são discutidos os equipamentos a bordo de um UAV e, em particular, sua adequação ao projeto proposto. Muitos tipos de UAVs necessitam de uma comunicação entre a aeronave e a estação de solo, devendo esta ocorrer em tempo real. São citadas algumas formas aplicáveis de transmissão de dados e as técnicas para manter a sua consistência durante a transmissão. Na seção 2.5 , são mostradas as diversas possibilidades de exploração de um sistema UAV e, na seção 2.6 , o mercado estimado para UAVs e a sua perspectiva de crescimento nos próximos anos. Os projetos que estão em desenvolvimento, bem como suas metas, equipamentos e recursos utilizados são apresentados na seção 2.7. Uma comparação desses projetos é feita na seção 2.8 . Finalmente, na seção 2.9 , são apresentadas as considerações finais deste capítulo.

\subsection{Definições e Escopo do Trabalho}

\subsubsection{Definições}

O conceito de aeronave não tripulada tem acompanhado quase toda a história da 
aviação. Os primeiros projetos na área militar consistiam em bombas ou alvos não tripulados. Entretanto, a maioria desses projetos nunca ultrapassou os limites do papel.

Existe uma variedade de termos para designar aeronaves não tripuladas. Essas aeronaves podem ser chamadas de UAVs (Unmanned Aerial Vehicle), UAVs (Unoccupied Air Vehicle) ou UMAs (Unmanned Aircraft). Segundo Siuru [SIU91], estes são os termos mais usados embora existam outros como UVSs (Unmanned Vehicle System), SPVs (Self Piloted Vehicle), UTAs (Unmanned Tactical Aircraft). Os UAVs são aeronaves que possuem um sistema de navegação automático total ou parcial que permite vôos autônomos com rotas préprogramadas, recebendo atualizações periódicas através de uma estação terrestre ou aérea, para correção de sua rota [SIU91].

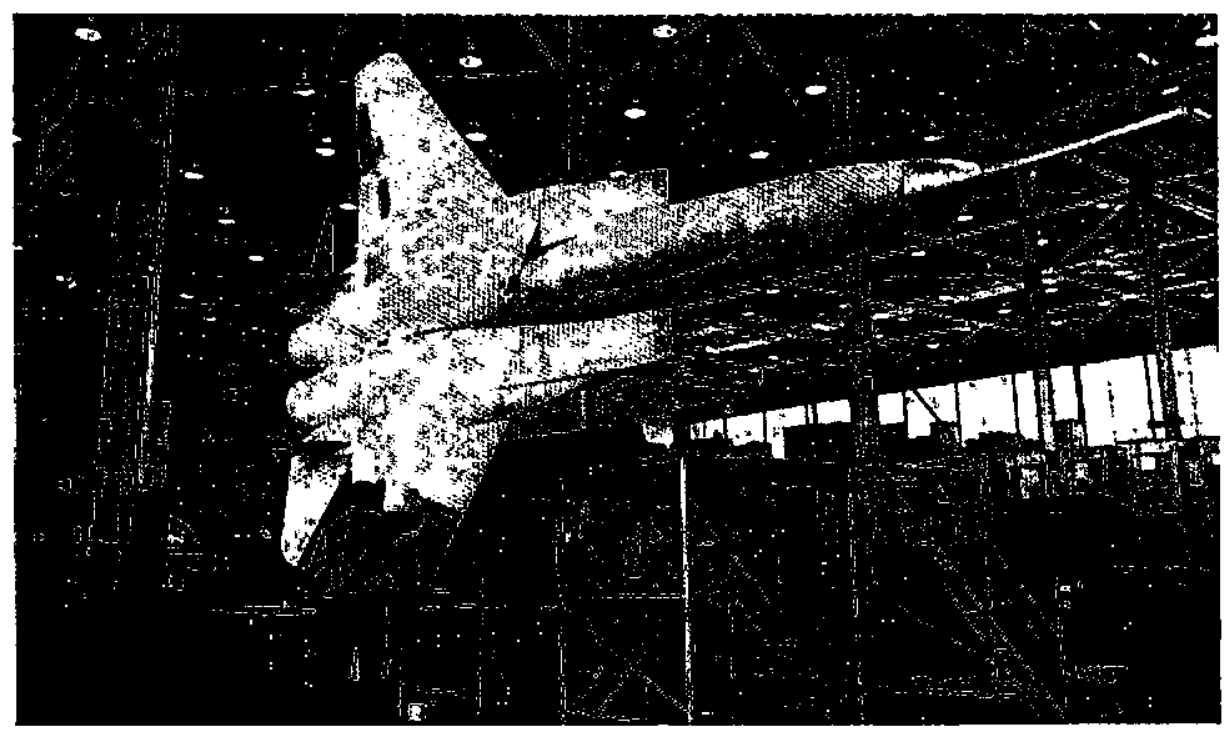

Figura 2.1 RPRV do F-15 em escala de 3/8.

Um veículo do tipo RPV (Remotely Piloted Vehicle) implica que a aeronave está sendo seguida por um piloto humano em terra ou por um outro avião [SIU91]. Um RPV pode ser considerado um aeromodelo rádio-controlado ( $\mathrm{R} / \mathrm{C}$ ) sofisticado utilizando basicamente as mesmas técnicas utilizadas pelos aeromodelistas amadores. Os RPRVs (Remotely Piloted Research Vehicle) são RPVs em escala reduzida para aplicação em pesquisa. Eles são utilizados pelos engenheiros para estudar o comportamento das aeronaves, tais como pouso, decolagem e testes em túnel de vento [SIU91]. Na figura 2.1, pode-se observar um exemplo típico de RPRV.

As siglas podem assumir outros nomes em função da aeronave utilizada e do projeto de pesquisa relacionado, tal como RPH (Remotely Piloted Helicopter) para helicópteros, DAAV (Dirigible Autonomous Aerial Vehicle) para dirigíveis e AROD (Airborne Remotely Operated 
Device) [SPA99]. A sigla UAV engloba qualquer aeronave não tripulada, com ou sem asas, assistida por um operador terrestre ou aéreo.

\subsubsection{Aeronaves Não Tripuladas}

\subsubsection{Tipos de Aeronaves}

As aeronaves sem piloto podem variar em sua estrutura, tamanho e modelo. Os tipos aqui apresentados são as ocorrências mais comuns.

\section{Aviões}

Os primeiros projetos de UAVs que surgiram durante a Primeira Guerra Mundial foram do tipo avião [SIU91]. Os projetos de UAVs desse tipo podem apresentar tamanhos variando de alguns metros a poucos centímetros. A DARPA (Defense Advanced Research Projects Agency) criou recentemente um micro avião de $15 \mathrm{~cm}$ para missões de espionagem, conhecido por MAV (Micro Aerial Vehicle) [WHA99].

Os UAVs deste tipo podem ser cópias dos aviöes de combate com a finalidade de confundir o inimigo na linha de guerra ou aeronaves com projeto inovador. Os UAVs voltados para aplicações militares conseguem atingir elevadas altitudes e alguns possuem longa permanência no ar (por exemplo, o Model 305 fire-bolt que atinge $25.000 \mathrm{~m}$ de altitude e 80 horas de autonomia).

Os UAVs para aplicações civis, que utilizam aviōes, têm como base aeronaves do tipo R/C. Estas aeronaves normalmente são em tamanho pequeno, e algumas vezes, réplicas em escala reduzida de uma aeronave convencional. São geralmente construídas com madeira balsa e recobertas com plástico.

O lançamento desses UAVs pode ocorrer através de plataformas lançadoras, podendose utilizar algum jato propulsor semelhante ao BQM-34A Firebee (figura 2.2 à esquerda [SIU91]), ou serem lançados por uma catapulta (figura 2.2 à direita). Outras formas de lançamento são através de uma aeronave hospedeira ou por decolagem de uma pista terrestre, sendo esta a mais comum. $O$ pouso pode ser convencional ou feito através de redes de coleta ou pára-quedas. 

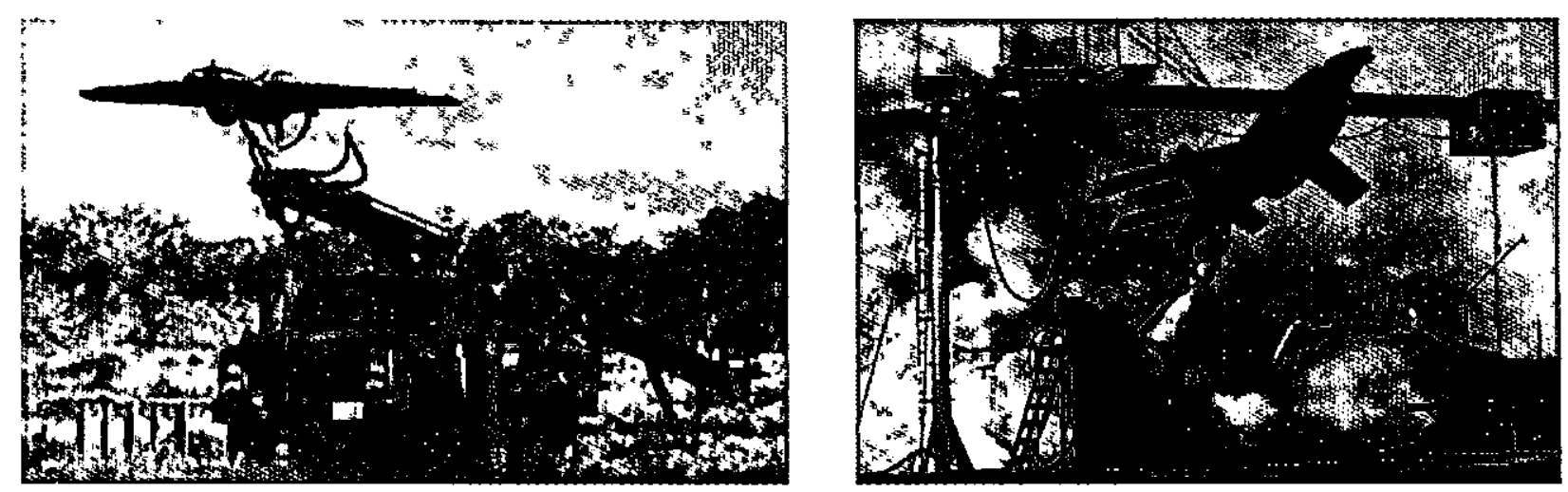

Figura 2.2 Exemplos de duas maneiras de decolagem de UAVs.

\section{Helicópteros}

Os helicópteros foram os UAVs com maior sucesso entre 1950 e 1960 [SIU91]. Esse tipo é chamado de RPH (Remotely Piloted Helicopter). O primeiro helicóptero construído foi o tiny Model 2B em 1949, seguido pelo X-RON-1 em 1950 e ambos eram helicópteros tripulados. Este modelo foi modificado pela Gyrodyne Company para ser remotamente pilotado. Essa modificação foi conhecida como sistema DASH (Drone Anti-Submarine Helicopter). Nos anos seguintes, quase 800 helicópteros do modelo QH-50s (figura 2.3) foram construídos, sendo equipados com motores que variavam de $70 \mathrm{hp}$ (motores Prose), a $330 \mathrm{hp}$ (motores Boeing turboshaft). Este modelo provou que era capaz de realizar salvamento, iluminar alvos e descer sobre neblina.

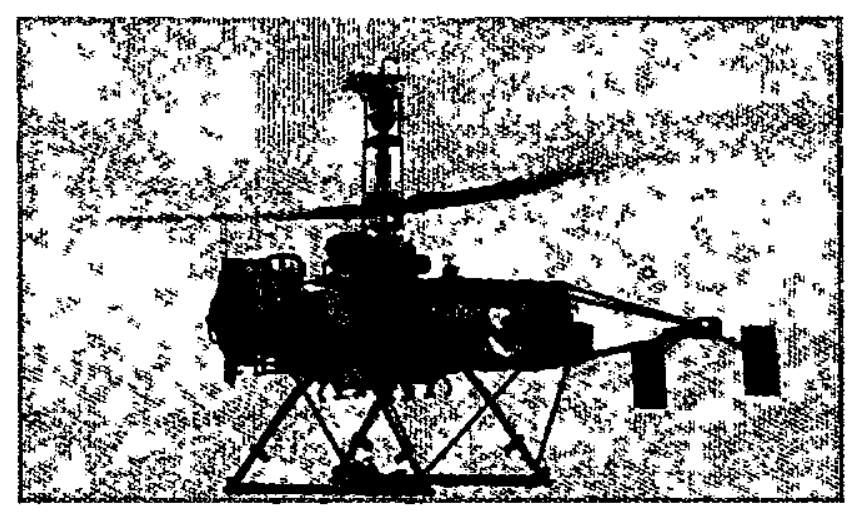

Figura 2.3 RPH modelo QH50s.

Os RPHs utilizados para aplicações comerciais, em sua maioria, têm como base os helicópteros $\mathrm{R} / \mathrm{C}$ com sistema de propulsão que, tipicamente, pode variar de 2 a $5 \mathrm{hp}$. A estrutura dos helicópteros pode ser feita em plástico ou liga de alumínio e seu tamanho pode variar em função da sua aplicação e da necessidade da carga útil que deverá ser transportada a bordo. A 
Universidade de Stanford atualmente está trabalhando com um sistema UAV autônomo, utilizando o modelo Schluter Futura R/C com motor de 5 hp [WOO99].

\section{Dirigíveis}

Dirigível é um veículo aéreo que sobe pela utilização de um gás (LTA - Lighter-ThanAir) mais leve que o ar, contido em um "vasilhame" (ou em células separadas envolvidas por uma outra estrutura). A sua ascensão é favorecida por sua aerodinâmica [RIG99] e pode, opcionalmente, ser complementada com motores adicionais para decolagem e para mover-se através do ar. Um $\mathrm{m}^{3}$ de hidrogênio, hélio ou ar quente possibilitam a suspensão de $1,1 \mathrm{~kg}, 1 \mathrm{~kg}$ e $0,3 \mathrm{~kg}$ de carga útil, respectivamente [AIR99]. Os dirigíveis são ideais para aplicações que envolvem monitorização ambiental, em função de suas velocidades baixas e da capacidade de ficarem suspensos no ar sem produzir ruídos. Podem ser rígidos ou semi-rígidos [AIR99].

\section{- Dirigível Rígido}

Os dirigíveis rígidos apresentam uma estrutura interna tradicionalmente feita em ligas de alumínio, o que proporciona sua forma peculiar. Os mais famosos deles foram os Zeppelins e o USS Akron da Macon. Em geral, os mesmos só passam a ser eficientes a partir dos 120 metros de comprimento, levando em consideração o raio da circunferência do volume do dirigível e o peso.

\section{- Dirigível Semi-Rígido}

Os dirigíveis semi-rígidos mantêm sua forma pela pressão exercida do gás de levantamento sobre o envelope ou coberta, sendo complementada por uma quilha interna ou externa. $O$ mais famoso deles foi construído pelo brasileiro Alberto Santos-Dumont [AIR99].

\section{Balão}

Semelhante ao dirigível, o balão é um veículo aéreo que sobe em função do gás mais leve que o ar. Em sua forma tradicional, não existe controle de navegação, com exceção do controle de pouso e decolagem. A sua forma é mantida através da pressão interna sobre o envelope, tal como nos balões de publicidade. Esta classe é utilizada como UAV pela praticidade do seu transporte. Entre os projetos que utilizam este tipo de aeronave pode-se citar o projeto AIM UAV do Colorado Space Grant College e o AURORA da Universidade de Campinas. 


\subsubsection{Tipos de Sistemas com UAVs}

Souza [SOU99] classifica os sistemas de UAVs em três tipos, conforme o nível de complexidade que apresentam:

- Tipo I - sistema baseado em aeromodelos convencionais, dispondo de câmeras fotográficas ou de vídeo a bordo, que podem ser controladas remotamente. As imagens da câmera de vídeo são transmitidas e recebidas por aparelhos de TV convencionais adaptados ou não para essa finalidade;

- Tipo II - sistema baseado em aeromodelos, especificamente projetado para a tarefa, dispondo de instrumentação de bordo completa e incluindo câmeras de vídeo específicas, podendo ser pilotados pelas imagens e dados transmitidos para um computador em solo;

- Tipo III - sistema do tipo II com equipamento computacional e softwares adequados a bordo, permitindo o vôo autônomo e a realização de missões de forma autônoma.

\subsection{Elementos Básicos de Aeronaves}

\subsubsection{Helicópteros}

Os elementos básicos que compõem um helicóptero são: o rotor principal, o rotor de cauda, o conjunto moto-propulsor, a fuselagem e o trem de pouso.

No rotor principal estão conectadas as pás ou asas rotativas (rotor blades) e os paddles ou flybar paddles que ajudam na estabilidade do helicóptero [JON99]. O helicóptero responderá mais lentamente com paddles mais espessos, ao passo que com os mais finos, o tempo de resposta será minimizado, tornando os controles mais sensíveis [JON99].

As pás principais desempenham a mesma função das asas do avião. Quando se deseja uma mudança no plano vertical, muda-se o ângulo de ataque de cada pá. Isso é referenciado como collective pitch do rotor principal.

Para efetuar um movimento lateral incrementa-se o ângulo de ataque sobre uma das 
pás no ponto correspondente à direção do movimento desejado, reduzindo-se o ângulo na pá oposta. Isso provoca uma diferença na força de sustentação gerada pelas duas pás e o deslocamento horizontal do aparelho na direção desejada. O mecanismo que oferece essas mudanças sobre as pás é o swash plate. As pás do rotor principal estão conectadas a uma das seçōes do swash plate [JON99].

O rotor da cauda é utilizado para contrapor o movimento de rotação do helicóptero induzido pelo torque do rotor principal [JON99]. Ele também é utilizado para alinhar o eixo longitudinal da aeronave conforme desejado.

Na cauda, encontram-se duas superfícies estabilizadoras, uma vertical e outra horizontal, para auxiliarem a aeronave durante vôos rápidos e no processo de subida e descida [JON99].

Um outro componente básico nos helicópteros em escala reduzida é o giroscópio. Ele atua como um compensador do movimento de guinada (yaw), atuando sobre o rotor da cauda. A função do giroscópio é compensar, de forma automática, o torque induzido pelo rotor principal.

\subsubsection{Aviões}

Os elementos básicos que compõem um avião estão divididos em três grupos: estrutura (asas, fuselagem, empenagem, superfície de controle, carenagem, etc.), moto-propulsor (motor e hélice) e sistemas (trem de pouso, controles, ignição, instrumentos indicadores, alimentação de combustível, etc.) [PRO96].

\section{Estrutura}

Asas - são os principais planos horizontais fixados em cada lado da fuselagem e são responsáveis pela produção da força que mantém os aviões suspensos no ar. Quando existe apenas um plano de fixação, o avião é chamado de monoplano. Existem aviōes biplanos e mesmo triplanos. Quando as asas são fixadas na parte inferior do avião, ele é conhecido como de "asa baixa". As asas também podem ser fixadas no meio ou em cima da fuselagem dando origem aos termos "asa média" e "asa alta".

Fuselagem - é o corpo central da aeronave, em forma de fuso. Nela são fixadas as asạs e a seção de cauda ou empenagem. O grupo moto-propulsor está normalmente 
fixado na parte frontal da fuselagem, a qual recebe o nome de nariz. Os equipamentos eletrônicos e o combustível estão dentro da fuselagem.

Empenagem - também chamada de cauda, está fixada na parte traseira da fuselagem. $O$ seu objetivo é estabilizar os movimentos da aeronave nos eixos vertical e transversal. A empenagem se divide em: estabilizador horizontal (onde estão conectados os profundores) e estabilizador vertical (onde está conectado o leme).

Superficies de Controle - As superfícies de controle do avião são os planos móveis presentes nas asas e na empenagem. Através deles pode-se mudar 0 comportamento da aeronave quanto à altitude e atitude. São eles [PRO96]:

Ailerons - são superfícies móveis instaladas nos bordos de fuga de cada asa. Eles realizam movimentos para cima e para baixo de forma alternada, ou seja, quando um está para cima o outro está para baixo. Estas superfícies de controle permitem o movimento de rolagem (roll).

Flaps - são superfícies de comando auxiliar, também instaladas na asa. Quando recolhidos, fazem parte do corpo das asas. Os flaps possibilitam mudar as características de vôo em baixa velocidade do avião possibilitando pousos e decolagens em menores velocidades.

Leme - o leme de direção é a superfície móvel conectada ao plano estabilizador vertical da empenagem. O leme possibilita girar a aeronave em torno do eixo de guinada (yaw).

Profundor - está fixado no bordo de fuga do estabilizador horizontal (plano horizontal da empenagem). Através dele, a aeronave muda sua atitude com relação ao horizonte, elevando ou abaixando o nariz (pitch).

Compensadores - os compensadores são pequenas superfícies de controle auxiliar conectadas às superfícies de controle principais. Essas superfícies permitem o nivelamento do vôo do avião, neutralizando o esforço sobre os comandos.

Carenagem - são capas removíveis colocadas sobre as rodas e o motor com 0 objetivo de melhorar as características aerodinâmicas do avião. 


\section{Moto-propulsor}

É composto pela hélice e pelo motor que, geralmente, estão na parte frontal da fuselagem. Outras configurações possíveis incluem o motor na parte traseira da fuselagem, na parte de cima e nas asas. O motor está fixado sobre hastes normalmente metálicas, o berço do motor. A hélice está presa ao eixo do motor e recebe uma carenagem cônica chamada spinner.

\subsubsection{Dirigíveis e Balões}

Os principais componentes dos dirigíveis e balōes são os seguintes:

\section{Envelope ou Armação}

Os dirigíveis têm um envelope flexível na forma de um charuto, forma esta mantida pela pressão interna de um gás. O envelope do balão pode ser construído com diversos materiais, sendo os mais comuns o vinil, o nylon metalizado ou mylar metalizado [AIR99a].

\section{Gôndola}

É um cesto ou caixa onde são transportados os equipamentos ou passageiros.

\section{Sistema de Propulsão}

O motor utilizado no dirigível pode ser a combustão ou elétrico. É fortemente aconselhável o uso de motores elétricos [AIR99a], pois fornecem maior precisão de subida. São mais pesados do que os motores a combustão, desenvolvendo baixa velocidade. Entretanto, não desequilibram o dirigível conforme o consumo da carga das baterias. No caso dos balões que funcionam com ar quente, os queimadores funcionam como motores, exercendo a função de erguer e pousar o balão. O motor pode estar acoplado do lado de fora ou atrás dos dirigíveis. Uma outra alternativa é mantê-lo em gôndolas separadas, um em cada lado do dirigível, semelhante ao Zeppelin. Os queimadores e os tanques também ficam dentro da gôndola [AIR99a]. 


\section{Leme}

Ele é necessário para permitir o controle no dirigível e também para manter sua estabilidade.

\subsection{Instrumentação e Equipamentos Utilizados em UAVs}

\subsubsection{Instrumentação de Bordo}

Segundo Souza [SOU99], define-se vôo não visual de um UAV como sendo o vôo realizado sem a visão direta da aeronave. Essa definição é conflitante com a definição de vôo não visual em aeronaves tripuladas (vôo por instrumentos). Para realizar o vôo não visual com pilotagem remota em um UAV são necessários alguns instrumentos para que o piloto no solo possa se orientar quanto ao comportamento e posição da aeronave. Os instrumentos podem ser divididos em duas categorias: os que informam as condições operacionais da aeronave e características do vôo e os que indicam o seu comportamento [SOU99].

Os instrumentos que indicam a condição operacional da aeronave são:

- Instrumentos do motor

o Sensor de rotação (tacômetro) - informa o número de rotações por minuto do motor;

- Sensor de temperatura;

- Sensor de pressão do óleo;

- Sensor indicador da temperatura dos gases do escapamento.

- Indicador de combustível.

Os instrumentos abaixo indicam as características do vôo e a posição da aeronave:

- Bússola - indica ao piloto onde está o norte magnético;

- Bússola giroscópica - semelhante à bússola (ver figura 2.4), porém não é afetada por balanços ou inclinações da aeronave. Entretanto, ela somente é capaz de indicar a direção após ser ajustada [PRO96]; 
- Horizonte Artificial ou Indicador de Atitude - indica a posição do avião em relação ao horizonte (pitch e roll) [PRO96]. Sua aparência é mostrada na figura 2.4;

- Altímetro - indica a altitude, em pés, em relação ao nível do mar, conforme mostrado na figura 2.5 (à esquerda);

- Coordenador de curvas (Turn and Bank) - indica a inclinação das asas, conforme mostrado na figura 2.5 (à direita);

- Indicador de velocidade do ar;

- GPS (Global Positioning System) - sistema de posicionamento global que utiliza 24 satélites colocados em 6 бrbitas diferentes, e um receptor em terra. Com ele $\hat{\varepsilon}$ possível localizar qualquer ponto no globo terrestre com precisão que varia de alguns centímetros a algumas centenas de metros;

- Variômetro ou Indicador de Subida (climb) - indica a razão de subida ou descida fornecida em pés por minuto [PRO96];

- Radar de ultra-som - pode indicar baixas altitudes (algumas dezenas de metros) da aeronave, com precisão de milímetros.
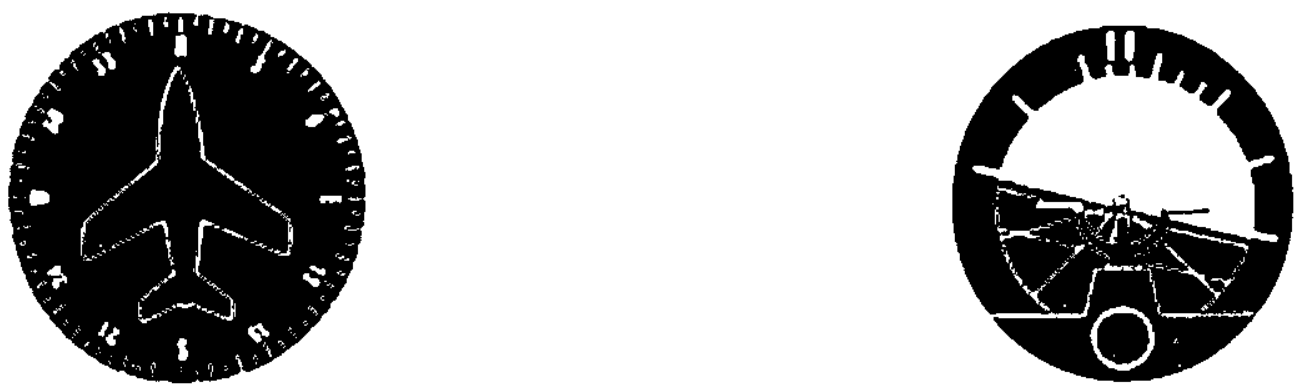

Figura 2.4 Bússola giroscópica e indicador de horizonte artificial. 

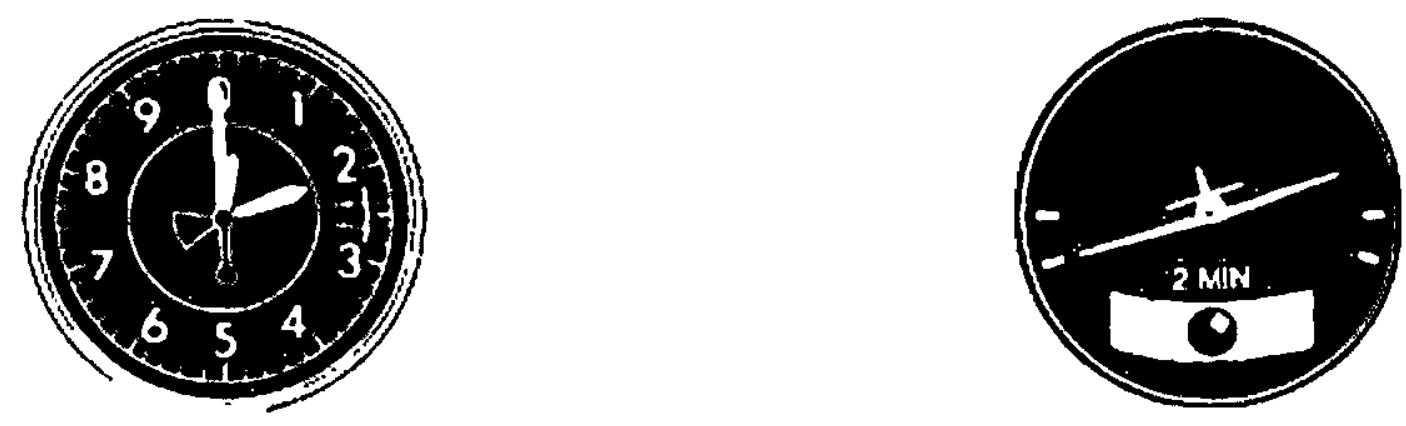

Figura 2.5 Altímetro e coordenador de curva.

Muitos desses instrumentos podem ser substituídos por outros mais modernos, conforme a aplicação. Alguns deles podem ser substituídos pelo GPS.

A instrumentação citada é essencial para a realização de um vôo não visual e vôo autônomo da aeronave. Vários outros sensores podem ser instalados conforme a aplicação desejada do UAV.

\subsubsection{Conjuntos Moto-propulsores}

Os motores que equipam os UAVs podem variar desde motores elétricos especializados até jatos-propulsores, permitindo vôos com velocidades muito altas, como é o caso do Beech MQM-107 usado pelas forças armadas do EUA [SIU91]. Embora exista uma grande variedade de motores, são enfocados apenas os que equipam os aeromodelos comerciais, em função do escopo deste trabalho.

Os aeromodelos podem ser equipados com motores elétricos, motores glow de 2 ou 4 tempos [ANG99] e motores a gasolina. Recentemente, têm sido introduzidos motores a jato que utilizam como combustível gás ou querosene. Cada um dos motores citados tem vantagens e desvantagens e são largamente usados em aeromodelos R/C [EWI99]. A escolha do motor que equipará a aeronave variará em função da sua aplicação, da carga útil que se deseja transportar e da duração do vôo.

Nos últimos anos, com o vasto aperfeiçoamento nas baterias de NiCad (níquelcádmio), principalmente na redução do tamanho e no aumento da capacidade de carga, tornou-se viável equipar as aeronaves com motores elétricos. 
A grande vantagem dos motores elétricos é o seu funcionamento limpo e silencioso, ideal para aplicações de monitorização ambiental e para a realização de fotos aéreas, já que não há vibração do motor [RSR97].

Os motores elétricos usualmente têm um núcleo com ferrite e operam em rotações muito elevadas. O "Mabuchi 540" é o exemplo mais popular dessa classe de motores, existindo muitas variações desse modelo. As aeronaves que exigem maior potência podem utilizar os motores com imãs de cobalto e os motores sem escova, a um custo bem maior que os motores elétricos convencionais [EWI99].

A energia para o acionamento desses motores é usualmente fornecida por uma série de baterias de NiCad, em pacotes de seis ou mais células. Para motores com imãs de cobalto, é necessária uma grande quantidade de células.

As baterias de $\mathrm{NiCad}$ utilizadas podem ser recarregadas em algumas dezenas de minutos, entretanto o tempo proporcionado de vôo é curto: de 4 a 10 minutos [REC99].

Os motores à gasolina têm sido largamente usados nos modelos de carros, barcos e aviões [EWI99]. Esses motores não são adequados para aeronaves de pequeno e médio porte, em função do seu peso e tamanho. Entretanto, fomecem boa potência e consomem pouco combustível. Suas vantagens principais são a economia de combustível, a confiabilidade de funcionamento e a autonomia de vôo que pode durar até dias [SOU99]. Um sistema de ignição com vela é necessário para o funcionamento do motor.

Uma outra modalidade de motores utilizada nos aeromodelos são os motores do tipo glow, que existem normalmente nas versões de 2 e 4 tempos. O combustível para este motor é baseado em uma mistura de metanol com óleo lubrificante. Para catalisar o processo de explosão do combustível, usa-se um elemento aquecido chamado glow plug. Na partida do motor utilizase uma bateria para aquecê-lo. Tipicamente os motores glow variam de 0.49 a 1.2 polegadas cúbicas $(0.80 \mathrm{cc}$ to $20 \mathrm{cc})$.

Os motores dos helicópteros são similares aos que equipam os aviões. Nos motores a explosão, é necessária uma superfície de refrigeração maior, permitindo uma melhor dissipação de calor [EWI99a].

A hélice faz parte do conjunto moto-propulsor e está presa ao eixo do motor. $O$ tamanho da hélice é descrito por dois números: o diâmetro e o passo em polegadas. Por exemplo, uma hélice $10 \times 6$ tem 10 polegadas de diâmetro e 6 polegadas de passo. $O$ passo é descrito 
como a distância que a hélice se moverá para frente em um meio sólido, funcionando como um parafuso. Isto significa que ao rodar uma hélice $10 \times 6$ a aeronave deverá mover-se para frente em $15,24 \mathrm{~cm}$ (6 polegadas) a cada volta, assumindo que isto seja feito com $100 \%$ de eficiência.

\subsubsection{Equipamentos de Rádio-Controle}

Semelhante a todos os emissores de rádio, um transmissor $\mathrm{R} / \mathrm{C}$ emite um sinal com um comprimento de onda específico, que é conhecido como frequiência [TOW99a]. Nas estações de rádio comerciais, cada operadora trabalha em sua própria frequiência, legalmente regulamentada por um órgão de telecomunicação. $O$ transmissor $R / C$ também tem a sua própria freqüência.

Os transmissores podem dispor de vários canais de comunicação, normalmente entre 2 e I0. Esses canais modulam a onda portadora do transmissor em AM (Amplitude Modulada) ou FM (Freqüência Modulada). Os rádios FM podem utilizar codificação PPM (Pulse Position Modulation) ou PCM (Pulse Code Modulation). Rádios do tipo PCM utilizam computadores para codificar os sinais, reduzindo a interferência e aumentando a precisão do rádio. A utilização de computadores permite uma série de funçães adicionais relacionadas com a interação entre os canais e a curva de atuação dos joysticks.

Para evitar problemas com interferência, foi realizada uma divisão nas faixas de freqüuência e três grupos de modelismo foram definidos: aviões, superfície e outros:

1. Somente Aviões - 72 megahertz, 50 canais numerados de 11 a 60 ;

2. Somente Superfície - 75 megahertz, 30 canais numerados de 61 a 90 ;

3. Outros Usuários - 27 megahertz, 6 canais numerados de A1 a A6 - embora esses canais possam ser utilizados em veículos terrestres ou aéreos, deve-se evitar seu uso nesses últimos, pois podem ocorrer quedas devido à interferência.

Alguns rádios são equipados com um sistema de treinamento, chamado de Trainer System, utilizado para o ensino de vôo de aeromodelo. Esta característica permite que dois transmissores semelhantes sejam conectados por um cabo, sendo um mestre e um escravo. Segurando-se uma chave no transmissor mestre, o transmissor escravo tem total controle sobre a aeronave. Em situaçōes de emergência, como descontrole da aeronave, o instrutor solta a chave retomando o controle da aeronave. A figura 2.6 mostra a conexão de dois rádios de R/C. 


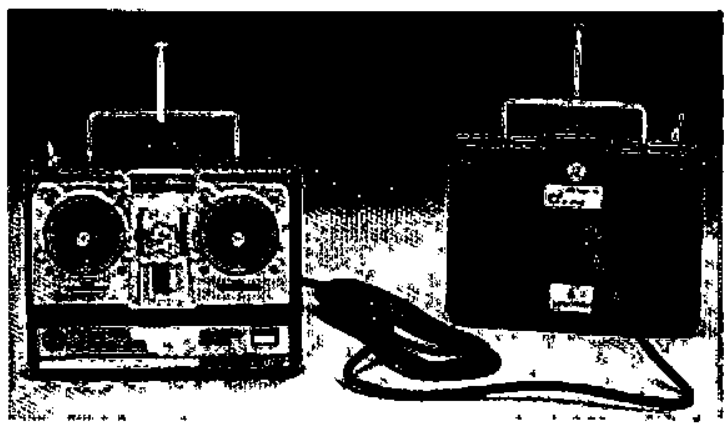

Figura 2.6 Sistema de treinamento utilizado nos R/C.

O número de canais de controle da aeronave varia conforme o tipo de aeronave [TOW99]. Cada canal de controle de um rádio pode acionar um ou mais controles da aeronave. Para um avião, é sugerido um rádio com 4 canais.

Quanto maior o número de canais, maiores são as possibilidades de controle. Se, por exemplo, for usado um rádio de 6 canais, é possível controlar características adicionais tais como: flaps, freios, pára-quedas e outras partes do aeromodelo. Pode-se usar um canal para controlar duas superfícies de comando ao mesmo tempo fazendo uma mistura eletrônica no transmissor.

Para receber os sinais do transmissor existe um receptor a bordo da aeronave que converte os sinais do rádio em sinais elétricos que acionam os servomecanismos (servos) de controle. Os servomecanismos fazem parte do equipamento de rádio controle. $O$ torque disponível para movimentar as superfícies de controle depende do modelo do servomecanismo. Algumas vezes é necessária a instalação de mais de um servomecanismo por superfície para a sua correta atuação quando submetida a esforços aerodinâmicos.

\subsubsection{Enlaces de Dados via Rádio}

Sistemas UAVs normalmente dispõem de alguma forma de comunicação de dados com o solo. Além dos canais de controle necessários para a operação de RPVs, dados devem ser transmitidos da instrumentação de bordo para permitir vôo não visual e deve existir a possibilidade de atualizações na rota ou missão de veículos autônomos. Esta operação deverá ser segura e livre de erros. Se houver algum erro no software de navegação do UAV e o link entre a aeronave e a estação terrestre não for confiável, provavelmente a aeronave cairá [SIU91].

O primeiro sistema de computador a utilizar radiodifusão em substituição a redes 
ponto a ponto foi o ALOHA [TAN96], tendo sido criado na década de 70 por Norman Abramson e seus colegas da Universidade do Havar. O desafio para a época era a interligação das ilhas havaianas, utilizando um canal de rádio compartilhado. A transmissão por rádio é baseada na instalação de uma antena de tamanho apropriado e um circuito eletrônico. Através deles, o sinal eletromagnético é propagado podendo ser recebido por vários receptores localizados em distâncias consideráveis [TAN96].

A maioria das transmissões utiliza uma banda de freqüência estreita para obter melhor recepção (muitos watts/Hz). No entanto, em alguns casos, o transmissor salta de frequiência em freqüência em um padrão regular, ou as transmissões se dispersam, intencionalmente, através de uma banda de freqưuência larga. Essa técnica é chamada spread spectrum, sendo muito utilizada nas comunicações militares, pois dificulta a detecção das transmissões, sendo praticamente impossível obstruí-las.

As ondas de rádio são fáceis de gerar, percorrem longas distâncias e penetram facilmente em casas, prédios, etc. Por isso são largamente utilizadas para comunicação em ambientes abertos ou fechados. Além disso, são onidirecionais, propagando-se em todas as direções.

O espectro eletromagnético é mostrado na figura 2.7. O rádio, as microondas, a radiação infravermelha e a radiação luminosa do espectro podem ser usados na transmissão de informações, desde que sejam moduladas a amplitude, a freqüência ou a fase das ondas. A radiação ultravioleta, os raios-x e os raios gama são boas opções para transmissão de dados já que possuem alta freqüência e grande capacidade de transmissão de dados. Entretanto, essas faixas do espectro são mais difíceis de modular e perigosas à saúde humana.

O volume de informações que uma onda eletromagnética é capaz de transportar está diretamente relacionado à sua largura de banda. Com a tecnologia atual, é possível codificar alguns bits por Hertz em frequiências baixas. Em freqüências mais altas esse número pode subir para 40 em determinadas condições.

As propriedades das ondas de rádio dependem da frequiência. Quando esta é baixa, as ondas de rádio atravessam bem os obstáculos, mas a potência cai rapidamente, com o aumento da distância entre o transmissor e o receptor. Em altas frequêencias, as ondas de rádio tendem a percorrer linhas retas e são refletidas por obstáculos, por exemplo, as microondas. Em qualquer frequiência, as ondas de rádio estão sujeitas à interferência de motores, chuvas e outras ondas geradas por equipamentos elétricos. Existe também a interferência entre os usuários e, por esta 
razão, faz-se necessário uma concessão do governo para utilizar um transmissor de rádio [TAN96].

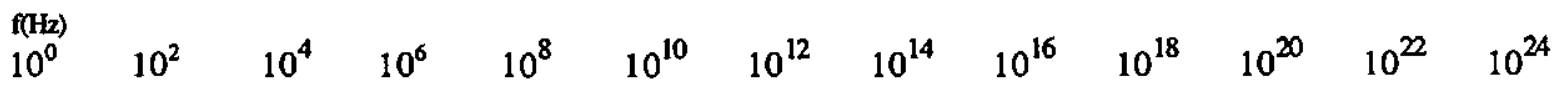

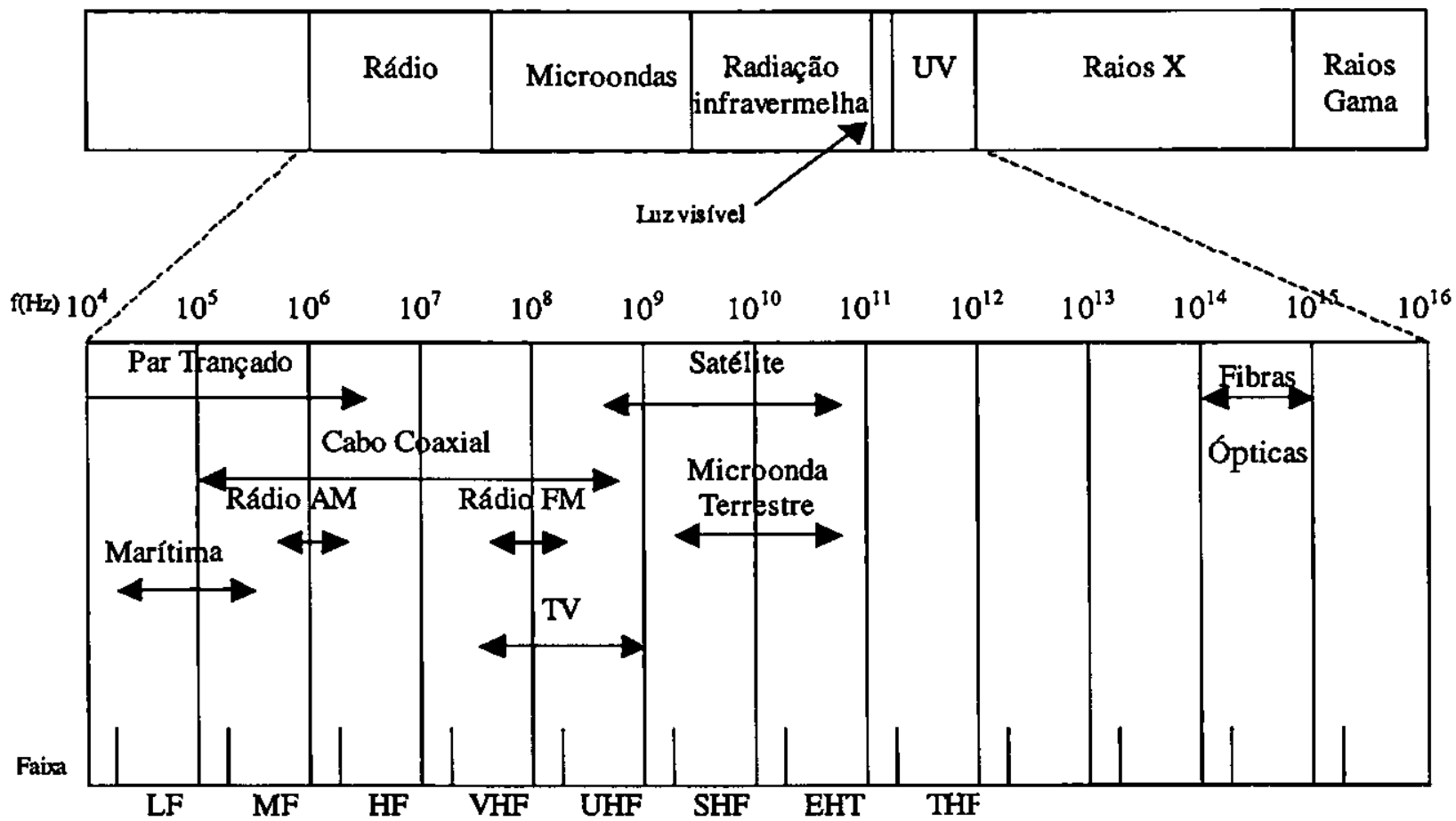

Figura 2.7 O espectro eletromagnético e a maneira como ele é usado na comunicação.

Nas faixas VLF (Very Low Frequency), LF (Low Frequency) e MF (Medium Frequency), as ondas de rádio se propagam no nível do solo. Nas freqüências baixas, essas ondas podem ser detectadas dentro de um raio de mil quilômetros, enquanto, nas mais altas, esse raio de ação pode ser bem menor. A radiodifusão em AM (Amplitude Modulada) utiliza a banda MF (Frequiências Médias) para transmissão a longas distâncias, sendo que, nesta freqüência, as ondas atravessam facilmente prédios e outros ambientes fechados. $O$ principal problema desta faixa é baixa carga de dados que podem ser transmitidos devido à pequena largura da banda.

\subsubsection{Técnicas e Protocolos para a Transmissão de Dados}

Nos primeiros projetos de redes de computadores foi dada maior prioridade para o hardware, mantendo-se o software em segundo plano. Atualmente, o software de comunicação entre os computadores está mais estruturado e foi dividido em camadas, permitindo que diferentes tipos de hardware comuniquem-se uns com os outros. Assim, uma camada de serviço 
comunica-se com outra em outra máquina correspondente. As regras e convenções definidas nessas camadas são chamadas de protocolos da camada $n$. Um protocolo pode ser definido como o conjunto de regras referentes à comunicação. Se uma camada deseja comunicar-se com uma camada inferior, esta deve obedecer à sua interface, que define as operações e serviços prestados à camada superior. Serviços e protocolos são conceitos diferentes. O serviço é um conjunto de primitivas (operações) que uma camada oferece para uma camada acima dela, como por exemplo, um serviço de entrega de mensagens sem perda (orientado à conexão).

Um conjunto de camadas de protocolos é chamado de arquitetura de rede [TAN96]. A especificação de uma arquitetura de rede deve conter informações suficientes para permitir que uma equipe de desenvolvimento possa criar um hardware ou software para comunicar-se adequadamente com outros computadores, através dos protocolos definidos nessa arquitetura.

Uma tentativa de padronização desses sistemas é referenciada como modelo ISO/OSI (International Standard Organization/ Open System Interconnection). Algumas das camadas no modelo ISO/OSI, como a de sessão e a de aplicação, têm pouco uso enquanto outras estão sobrecarregadas com funções, como é o caso da camada de enlace de dados e a de rede.

A comunicação entre uma aeronave e o solo é caracterizada por ser ponto a ponto [SOU99], operando no nível da camada de enlace de dados. Essa camada pode oferecer os seguintes tipos de serviços: sem conexão e sem confirmação; sem conexão e com confirmação; e com conexão e com confirmação.

No serviço sem conexão e sem confirmação, nenhuma conexão é feita entre o transmissor e o receptor. Os frames de dados são transmitidos para o receptor sem a espera de uma confirmação sobre a sua chegada. Esta classe de serviço é adequada onde à linha de comunicação é confiável e o tratamento de erros é realizado pelas camadas superiores, ideal para aplicações em tempo real.

No serviço sem conexão e com confirmação, não há conexão entre transmissor e receptor. Existe, entretanto, um controle sobre os frames recebidos. Assim, se um frame não chega em um determinado intervalo de tempo, o receptor solicita uma nova transmissão.

No serviço com conexão e com confirmação, o transmissor e o receptor precisam estabelecer previamente uma conexão. Cada frame é enumerado, garantindo que o frame não será duplicado ou perdido. Este serviço tem 3 fases: estabelecimento da conexão entre receptor e transmissor; transmissão dos frames e encerramento da conexão. 
Uma das técnicas utilizadas na camada de enlace de dados para a divisão dos dados em frames é através da contagem de caracteres. Antes de transmitir os caracteres, o transmissor coloca à frente o número de caracteres que serão transmitidos. Se durante a transmissão houver uma perda ou alguma inserção de caractere, devido a ruídos, o receptor não saberá o início e o término de cada frame. Para contornar esse problema, pode-se inserir caracteres de controle, técnica conhecida por preenchimento de caracteres. Antes de iniciar a transmissão, são inseridos os caracteres DLE STX e, ao final, os caracteres DLE ETX. Todas as vezes que aparecer um caractere DLE, o receptor sabe que o proximo é um caractere de controle. O problema acontece na transmissão de dados que contêm o caractere DLE. Nesse caso, é necessária a inserção de um segundo caractere DLE que pode ser detectado e retirado na recepção dos dados.

A terceira técnica utilizada é o preenchimento no nível de bits. Nesse caso, utiliza-se um padrão de bits para identificar o início de um frame, por exemplo, 01111110. Se na transmissão aparecerem cinco bits iguais a 1 em sequiência, é inserido um bit igual a 0 . Esse bit evita o aparecimento do padrão de início de frame no meio dos dados e ele pode ser facilmente retirado na recepção.

O controle de fluxo é outro ponto importante tanto na camada de enlace de dados como nas camadas superiores, pois, muitas vezes, o transmissor envia mais frames que o receptor pode manipular.

Os projetistas de redes têm desenvolvido várias formas para a correção e deteç̧ão de erros, uma das quais é a duplicação da informação na transmissão e a outra, a inclusão de informações suficientes para que o receptor seja capaz de deduzir que existe um erro nos dados e faça uma solicitação de retransmissão. O código de deteç̧ão/correção de erros de Hamming é um exemplo de técnica de correção de erros.

Técnicas de detecção de erros incluem a utilização de bits de paridade e CRC (Cyclic Redundancy Check), conhecidas também como divisão polinomial [TAN96]. Neste último método, tanto o transmissor quanto o receptor devem utilizar um mesmo polinômio gerador $G(x)$. Essa técnica consiste em dividir o frame de dados pelo polinômio $G(x)$ e transmitir o resto, gerado por esta divisão, somado ao frame original. Do outro lado, o receptor efetua a mesma divisão e, se o resto for 0 , pode concluir que oframe chegou sem erros.

Para construção de um UAV do tipo II, apresentado no trabalho de Souza [SOU99], foi definido um protocolo do tipo simplex para a transmissão de dados da instrumentação de bordo para o solo. Entretanto, para a fase II do Projeto ARARA o protocolo de Souza foi modificado 
com a inclusão de três novos campos: Temperatura do Motor, Bateria da Instrumentação e Bateria dos Servomecanismos. Os dados desses novos sensores são importantes para a operação da aeronave.

A tabela 1 descreve os dados transmitidos da instrumentação de bordo, e a figura 2.8 mostra o formato de um pacote de dados.

Tabela 1 Descrição dos dados contidos no protocolo de enlace de dados.

\begin{tabular}{|c|c|c|c|}
\hline Nome dón Dado, & 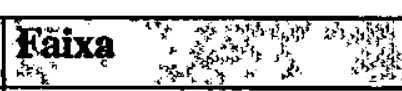 & 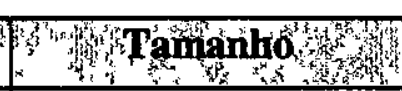 & Taxade Atualizacấ \\
\hline Nível Combustível & 0 a $100 \%$ & Inteiro 8 & Contínua \\
\hline Rotação & 0 a $20000 \mathrm{rpm}$ & Inteiro 16 & Contínua \\
\hline $\begin{array}{l}\text { Temperatura do } \\
\text { Motor }\end{array}$ & 0 a $500^{\circ} \mathrm{C}$ & Inteiro 16 & Contínua \\
\hline Temperatura Gases & 0 a $500^{\circ} \mathrm{C}$ & Inteiro 16 & Contínua \\
\hline Temperatura Local & $-50 \mathrm{a}+50^{\circ} \mathrm{C}$ & Inteiro 16 & Contínua \\
\hline Velocidade $\mathrm{Ar}$ & 0 a $300 \mathrm{~km} / \mathrm{h}$ & Inteiro 16 & Contínua \\
\hline Altitude & $-5000 a+5000 m$ & Inteiro 16 & Contínua \\
\hline Direção & 0 a $360^{\circ}$ & Inteiro 16 & Contínua \\
\hline $\begin{array}{l}\text { Bateria da } \\
\text { Instrumentação }\end{array}$ & 0 a $100 \%$ & Inteiro 8 & Contínua \\
\hline $\begin{array}{l}\text { Bateria dos } \\
\text { Servomecanismos }\end{array}$ & 0 a $100 \%$ & Inteiro 8 & Contínua \\
\hline Horizónte Artificial & $=8$ & $x^{2}$ & $y^{n^{*}}$ \\
\hline Arfagem & 0 a $360^{\circ}$ & Inteiro 16 & \\
\hline Rolamento & 0 a $360^{\circ}$ & Inteiro 16 & Contínua \\
\hline GPS & $\%$ & $\vec{m}$ & $y^{4} x^{4}$ \\
\hline Velocidade & 0 a $300 \mathrm{~km} / \mathrm{h}$ & Inteiro 16 & \\
\hline Latitude & $1+6,48 \mathrm{E} 8 \mathrm{~ms}^{\circ}$ & Inteiro 32 & \\
\hline Longitude & $-/+3,24 \mathrm{E} 8 \mathrm{~ms}^{\circ}$ & Inteiro 32 & Contínua \\
\hline Altitude & $-1+5 \mathrm{E} 5 \mathrm{~cm}$ & Inteiro 32 & \\
\hline Tempo & 0 a 863999 ds & Inteiro 32 & \\
\hline
\end{tabular}

\begin{tabular}{|l|l|l|l|}
\hline Header(1) & $\operatorname{Dados}(47)$ & \\
\hline
\end{tabular}

Figura 2.8 Pacote de dados. 
Os campos mostrados na figura 2.8 representam as seguintes características:

- Header - por definição, esse campo sempre apresenta o valor 01111110 ;

- Identificação dos pacotes - Cada pacote transmitido começa por um padrão especial de bits, o header, permitindo a separação dos pacotes utilizando a técnica de preenchimento de bits;

- Checksum - a soma (sem carry) de todos os bytes do pacote, desprezando-se o header, deve ser igual a zero.

Os dados transmitidos são utilizados para a atualização dos instrumentos na tela de controle. A taxa de atualização dos mostradores foi especificada como igual a l segundo. A taxa utilizada para a transmissão dos dados é o dobro da taxa máxima dos mostradores, ou seja, 2 pacotes/s. Os dados apresentados nos mostradores da tela poderão ser a média dos últimos " $n$ " pacotes recebidos sem erro, onde " $n$ " deve ser definido experimentalmente.

Taxa transmissão $=2$ pacotes $/ \mathrm{s}=100$ bytes $/ \mathrm{s}$

Essa taxa de transmissão permite a utilização de modems simples de $1200 \mathrm{bps}$, tal como Baycom [BAY99], utilizado em packet radio. O diagrama elétrico desse modem está à disposição, gratuitamente, através da Internet e o seu peso, custo e consumo de energia são baixos [SOU99].

\subsection{Aplicações dos UAVs}

\subsubsection{Na área militar}

Os UAVs realizam as missões mais perigosas [SIU91]. Estas missões normalmente acontecem atrás das linhas do inimigo. Os UAVs podem voar em regiōes contaminadas por armas NBC (Nucleares, Biológicas e Químicas), viajando em elevadas altitudes durante horas ou mesmo dias, em missões com alto risco de destruição [DEL.99].

Existem diferentes projetos de UAVs para missões militares. Os UAVs variam desde modelos simples, como uma aeronave utilizada para lazer, equipada com uma câmera de TV, até sistemas de complexidade equivalente a de aeronaves tripuladas. 
Um UAV pode operar em várias modalidades de alcances. Um UAV de pequeno alcance (cerca de $30 \mathrm{~km}$ ) pode ser utilizado para suporte tático local e em navios [SIU91]. Suas missões típicas incluem reconhecimento, destruição ou inutilização das comunicações inimigas. Também pode efetuar o patrulhamento no perímetro de uma base aérea para detecção de armas NBC e de bombas após um ataque.

Um UAV de alcance curto (entre 150 e $300 \mathrm{~km}$ ) pode ser utilizado para atingir alvos pré-definidos, interceptação de comunicações e detecção de armas NBC. Normalmente esse tipo de UAV é controlado remotamente. Seu vôo varia entre altitudes baixas e médias podendo ter longas durações.

Um UAV de alcance médio pode realizar missões de reconhecimento antes do início de um bombardeiro tripulado. Esse tipo de UAV tem um alcance máximo de $700 \mathrm{~km}$, sendo capaz de voar a velocidades muito altas [SIU91]. Pode ser lançado de um navio, uma estação terrestre ou mesmo de um avião. Durante o seu vôo é possível alterar seu curso ou controlá-lo remotamente por uma estação em terra. Toda essa sofisticação torna este tipo de UAV muito caro. A figura 2.9 [SIU91] mostra a foto de um UAV para missões de reconhecimento.

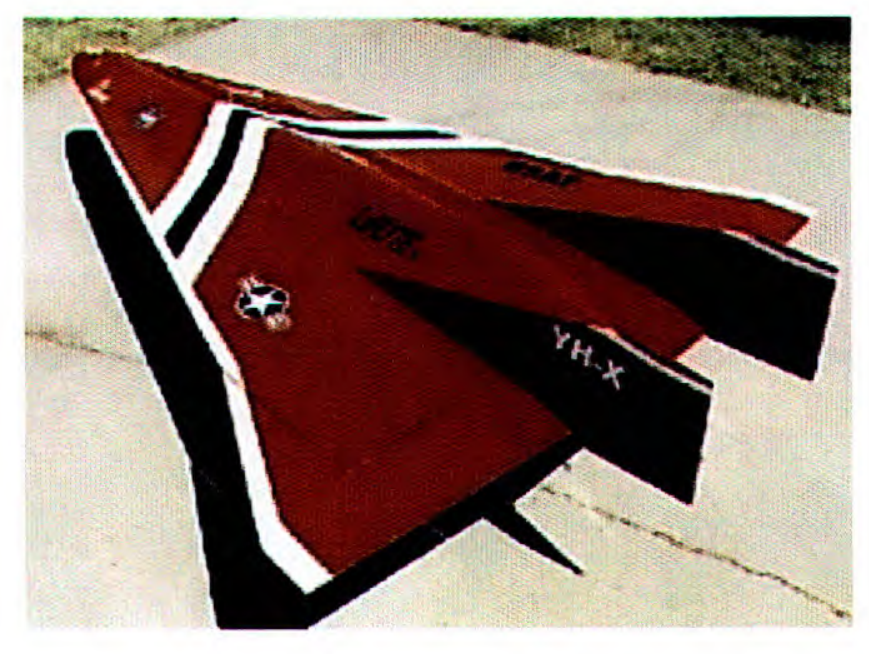

Figura 2.9 UAV utilizado para reconhecimento militar.

Os UAVs também podem ser utilizados em missões que exigem tempos de vôo mais longos. Durações típicas situam-se na faixa de 36 horas.

Um sistema UAV pode localizar minas terrestres. Equipado com sensores adequados e câmeras de TV, ele pode realizar essa tarefa com grande sucesso. Um estudo sobre este sistema pode ser encontrado em Morita [MOR99]. 


\subsubsection{Na agricultura}

A fotografia aérea aplicada à agricultura [THO99] é usada como um recurso de informação suplementar para o planejamento e análise de problemas, em alguns casos não perceptíveis ao nível do solo. Alguns exemplos de seu uso são: avaliação de danos causados por doenças, por insetos, pela ação dos ventos e pelo fogo, e ainda, problemas de aplicação de herbicidas e fertilizantes [SOU99]. A fotografia aérea também tem sido utilizada na avaliação da uniformidade de irrigação (ver figura 2.10), avaliação de novos produtos e mapeamento sistemático dos solos de caráter, geológico, topográfico e hidrológico, monitorização ecológica em casos de incêndio e devastação florestal, além de mineração e cartografia [KAD94] [SOU99] [JOR96]. Uma forma de adquirir estas fotos é com a utilização de aeronaves convencionais. Entretanto, seu custo operacional é muito alto quando comparado ao custo de um UAV.

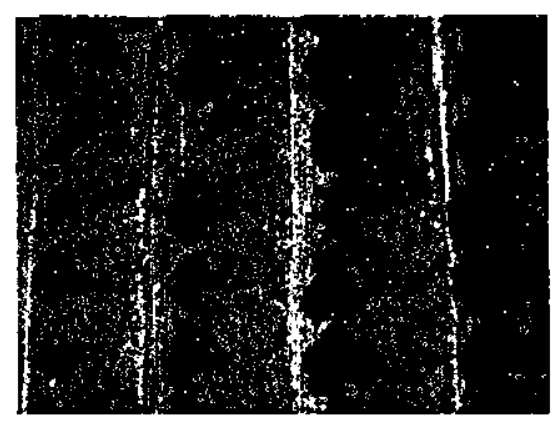

Figura 2.10 Foto aérea obtida por um UAV sobre um laranjal.

\subsubsection{Na ecologia}

As fotografias aéreas obtidas por UAV podem servir para o mapeamento de várias espécies vegetais, sendo especialmente úteis em lugares de difícil acesso como encostas de montanhas, vales, etc. Através de um UAV, equipado com um sistema de TV, é possível também realizar estudos sobre o comportamento dos animais, podendo-se fazer estimativas de suas colônias. A figura 2.11 ilustra este tipo de aplicação. As setas brancas indicam as tocas dos animais. 


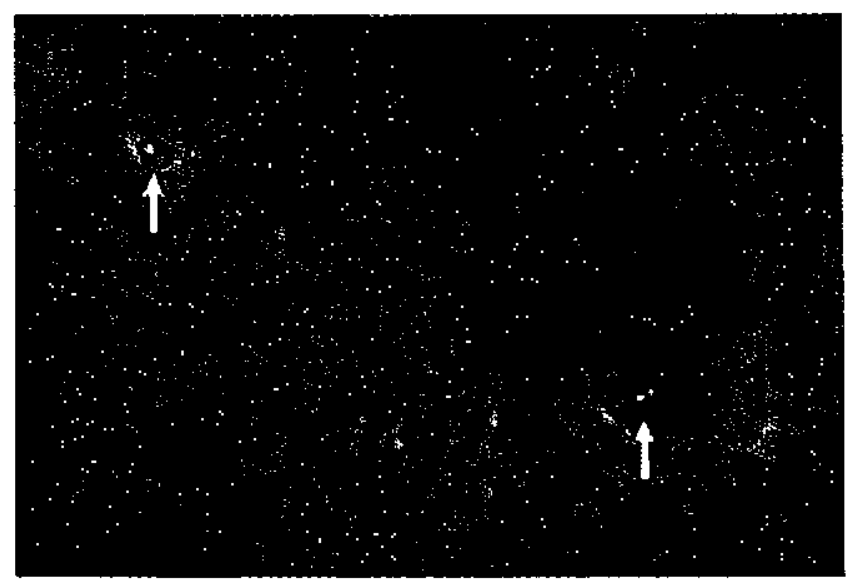

Figura 2.11 Foto obtida por um UAV para observar o crescimento dos cães da pradaria.

\subsubsection{Na arqueologia e história}

O reconhecimento aerofotográfico tem sido visto como um meio poderoso para a realização de descobertas arqueológicas. A Universidade de Cambridge está desenvolvendo um projeto importante para o reconhecimento, comparação e validação dos dados arqueológicos contidos nas fotos aéreas [WIL98].

\subsubsection{Na engenharia}

A visão aérea é importante na avaliação da estabilidade de declives naturais, barragens, pontes e outros empilhamentos feitos pelo homem. Uma outra utilização é no acompanhamento do fluxo de tráfego terrestre.

A fotografia vertical de precisão é o meio padrão para a preparação de mapas de contornos, essenciais para trabalhos de engenharia bem como para outras propostas, como demarcação de terrenos e fazendas, acompanhamento dos leitos dos rios, etc. [CAR99].

\subsection{6 $\mathrm{Na}$ indústria cinematográfica}

Com UAVs, um diretor de um filme pode, previamente, calcular uma cena com tomadas aéreas. Os UAVs podem voar precisamente sem a necessidade de um piloto humano para realizar, por exemplo, uma cena de perseguição. UAVs são utilizados com freqüência em cenas onde ocorre a destruição da aeronave, minimizando-se de forma radical o custo dessas 
tomadas. As câmeras instaladas no UAV podem servir como um olho aéreo para o diretor [CAR99].

\subsection{Mercado de UAVs}

O mercado de UAVs tinha como seu principal nicho as aplicações militares [SIU91], constituindo um mercado de milhões de dólares ao ano. Com a evolução da tecnologia e o barateamento da mesma, os UAVs tornaram-se acessíveis em aplicações civis. Apresentam potencial para produto de exportação, conforme demonstrado por alguns relatórios da indústria aeroespacial [WON99]. Na revista Flight International n. ${ }^{\circ} 19-25$ de Julho de 1995, pode-se ler o seguinte trecho:

"Quase 8.000 veículos aéreos não tripulados (UAVs) ao preço de US\$ 3.9 bilhões serão produzidos em todo o mundo entre 1994 e 2003. Espera-se dobrar o mercado de reconhecimento aéreo nos próximos dez anos, de acordo com a previsão anual do Teal Groups UAV".

“A previsão, publicada em 1995, para sistemas não tripulados na exposição organizada pela Association of Unmanned Vehicle Systems em Washington DC, estima que 5.250 alvos não tripulados ao preço de US\$ 1,3 bilhões e 2650 sistemas de reconhecimento ao preço de US\$ 2,6 bilhões serão produzidos nesta década. A estimativa não considera o custo relacionado com a estação de controle de solo, somente cobre o custo dos veículos aéreos, o qual constitui menos que $15 \%$ do custo de muitos sistemas de UAVs".

A figura 2.12 mostra outra avaliação do mercado de UAVs entre 1990 a 2002 feita pela Us-based Electronics Industries Association e apresentada em 1996 no encontro da Association of Unmanned Vehicle Systems International (simpósio AUVSI'96) em Orlando, Florida, USA. Ela mostra o crescimento do mercado de aplicações militares para os próximos anos. O mercado de UAVs direcionado para aplicações civis deve crescer significativamente nos próximos três anos.

Note que o mercado de UAVs para aplicações militares em 1992 gasta o equivalente a \$250 milhões e rapidamente se expande para \$ 600 milhões de dólares em 1997, com uma previsão de $\$ 700$ milhões para o ano de 2002. Entretanto, o mercado para aplicações civis já se equipara ao de aplicações militares e projeta para o ano de 2002 um sobressalto de $\$ 500$ milhões de dólares. 
Vários casos foram apresentados para utilização dos UAVs em aplicações civis tais como monitorização ambiental, pesquisa de tempo, auxílio à agricultura e exploração mineral durante o simpósio do AUVSI’96.

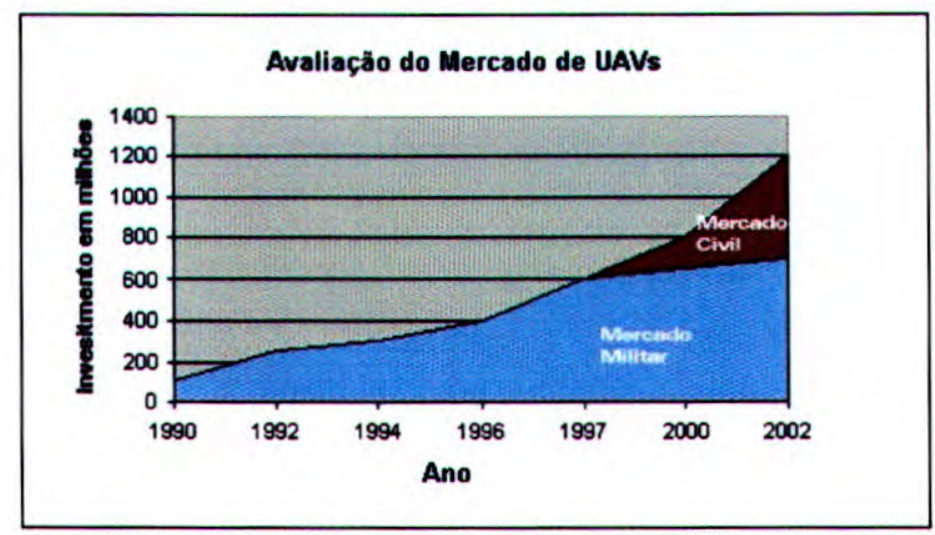

Figura 2.12 Avaliação do mercado de UAVs (1990-2002).

Segundo Wong [WON99a], nos últimos anos existiram poucos projetos comerciais nas áreas de monitorização ambiental, fotografia aérea e exploração de minerais. Esses campos têm mostrado uma promessa significativa de crescimento nos próximos anos. Contudo, o uso em larga escala dos UAVs é contrariado pela hesitação dos seus usuários potenciais para investir no seu desenvolvimento. Complementando, muitos desses usuários potenciais são desinformados sobre as pesquisas e organizações de desenvolvimento para implementação dos sistemas. Essas organizações, sem recursos, não são capazes de demonstrar a funcionalidade desses sistemas.

Embora existam muitos projetos de tais sistemas em operação ou em desenvolvimento pelo mundo, poucos poderiam ser considerados disponíveis para propósito comercial. $\mathrm{O}$ alto custo é devido, principalmente, ao fato da maioria dos sistemas ter sido desenvolvida e focada para o restrito mercado militar [WON99a]. Acredita-se que, com o desenvolvimento de projetos focados estritamente para o mercado civil, eles terão preços muito mais acessíveis.

\subsection{Outros Projetos de Pesquisa em UAVs}

Nesta seção são mostrados alguns projetos de UAVs que estão sendo desenvolvidos e aprimorados por algumas universidades e companhias. A maioria dos projetos aqui apresentados participa da AUVS (Association for Unmanned Vehicle System).

A IARC (International Aerial Robotics Competition) é uma competição que tem como 
objetivo básico demonstrar que um veículo aéreo autônomo completo pode realizar missões completamente autônomas. A missão proposta para o ano de 1999 foi:

- Decolar de um quadrado de $38 \mathrm{~cm}$ (15 polegadas) de lado em uma dada posição;

- Sobrevoar um campo gramado de $304 \mathrm{~cm}$ por $152 \mathrm{~cm}$ sem atravessar os seus limites;

- Determinar a localização de 5 barris de plástico de 22,7 litros em um campo aberto;

- Identificar o tipo de material contido no barril (tóxico, radioativo ou químico);

- Encontrar e recuperar um disco ferro-magnético localizado sobre um dos barris;

- Retornar à base de decolagem e pousar.

E importante mencioná-las para compreender o tipo de aeronave utilizado e sua instrumentação de bordo. Em função da primeira, da segunda e da quinta regra dessa competição, ficam eliminados quaisquer projetos que apresentem aeronaves com asas fixas, como os aviōes.

Nos projetos descritos abaixo são comentados itens como o tipo de aeronave, a instrumentação de bordo, os aparelhos de comunicação, a estação de solo, software e recursos envolvidos. Alguns projetos ainda são protótipos. Portanto, algumas partes dos itens acima mencionados ainda não estão implementadas.

\subsubsection{Universidade Stanford}

O projeto Autonomous Helicopter do Stanford ARL (Aerospace Robotics Laboratory) tem como objetivo o desenvolvimento de um UAV direcionado para a competição IARC [WO099]. O helicóptero Schluter Futura (ver figura 2.13) foi selecionado em função do seu baixo peso, alta capacidade de carga (carga útil de $11,35 \mathrm{~kg}$ ) e autonomia de vôo 15 minutos. $O$ modelo foi extensivamente modificado, particularmente em seu sistema de propulsão. $O$ motor do helicóptero tem potência de 5 hp e é do tipo glow.

O helicóptero está equipado com um computador PC-104 486 DX33 com 4 Mbytes de memória e uma $E^{2}$ PROM que emula um disquete de 360 Kbytes. Uma placa RS 422 modificada com duas portas seriais foi adicionada ao PC-104. O sistema operacional executado é o MS-DOS versão 3.3. Dois microcontroladores MC68HC81 IE2 da Motorola são utilizados para comandar os servomecanismos. 


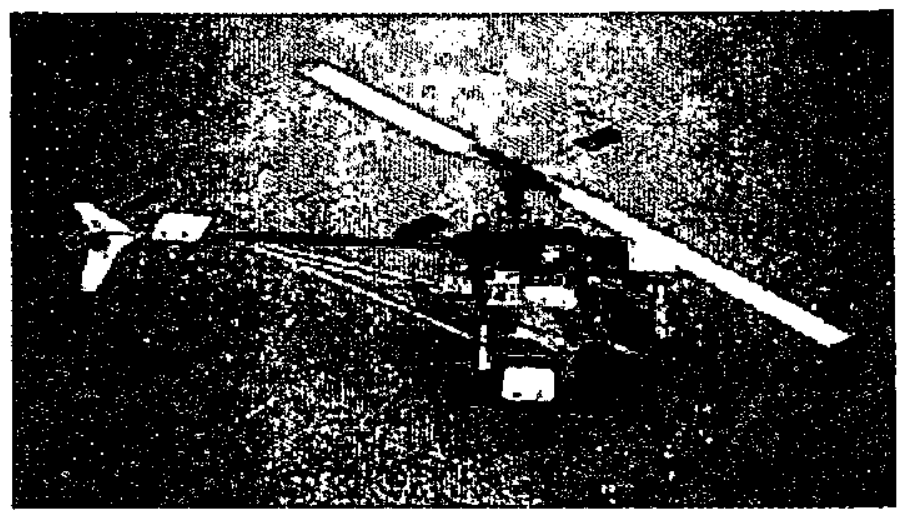

Figura 2.13 O helicóptero da Universidade de Stanford.

O UAV não utiliza nenhum sensor de navegação inercial devido ao alto peso e custo. A combinação de bússola magnética, giroscópio e sensores de ultra-som também foi eliminada devido a restrições de peso. A aeronave somente utiliza dois receptores de GPS para o sistema de navegação e um tacômetro para melhor controlar o subsistema de altitude. Duas câmeras de vídeo foram colocadas para permitir cálculo de visão estereoscópica pelos processadores de imagens do ambiente. Transmissores de vídeo foram montados no helicóptero, fornecendo imagens, ao vivo, para a estação de solo.

O helicóptero recebe sinais do receptor GPS utilizando quatro antenas independentes dispostas em forma de cruz. Todos os sinais recebidos pelas quatro antenas são tratados por um único GPS, o qual produz todas as informações necessárias para determinar a atitude do aparelho e sua variação. Uma das antenas tamberm alimenta um segundo GPS que decodifica, aproximadamente, metade das informações necessárias para determinar a velocidade e a posição da aeronave. Na estação de solo, uma quinta antena recebe um sinal semelhante ao que $\hat{~}$ recebido no ar. Este sinal é transmitido para a aeronave através de um modem por rádio operando a $461 \mathrm{MHz}$. Para economizar portas de interface na PC-104, o sinal é recebido pelo 68 HC1 I e transmitido para o 486. A figura 2.14 mostra detalhes desta ligação.

Com o sinal obtido pela antena terrestre, $e$ decodificada a segunda metade das informações necessárias para determinar a posição da aeronave, com $0,5 \mathrm{~s}$ de atraso. $O$ computador 486 realiza a comunicação com o receptor GPS, através de uma interface RS422 e efetua os cálculos da posição do veículo, sua velocidade, atitude e variação de atitude, determinando, então, o comando a ser aplicado nos servomecanismos do helicóptero. Estes comandos são enviados ao $68 \mathrm{HC} 11$ escravo que verifica se o sistema está habilitado para o modo automático ou manual. Quando no modo manual, todos os comandos gerados pelo 486 são 
ignorados e somente são executados os comandos recebidos pelo receptor do rádio. Caso os $68 \mathrm{HC} 11$ falhem, foi adicionado um servomecanismo extra que está conectado diretamente ao rádio da aeronave para cortar a alimentação do combustível.

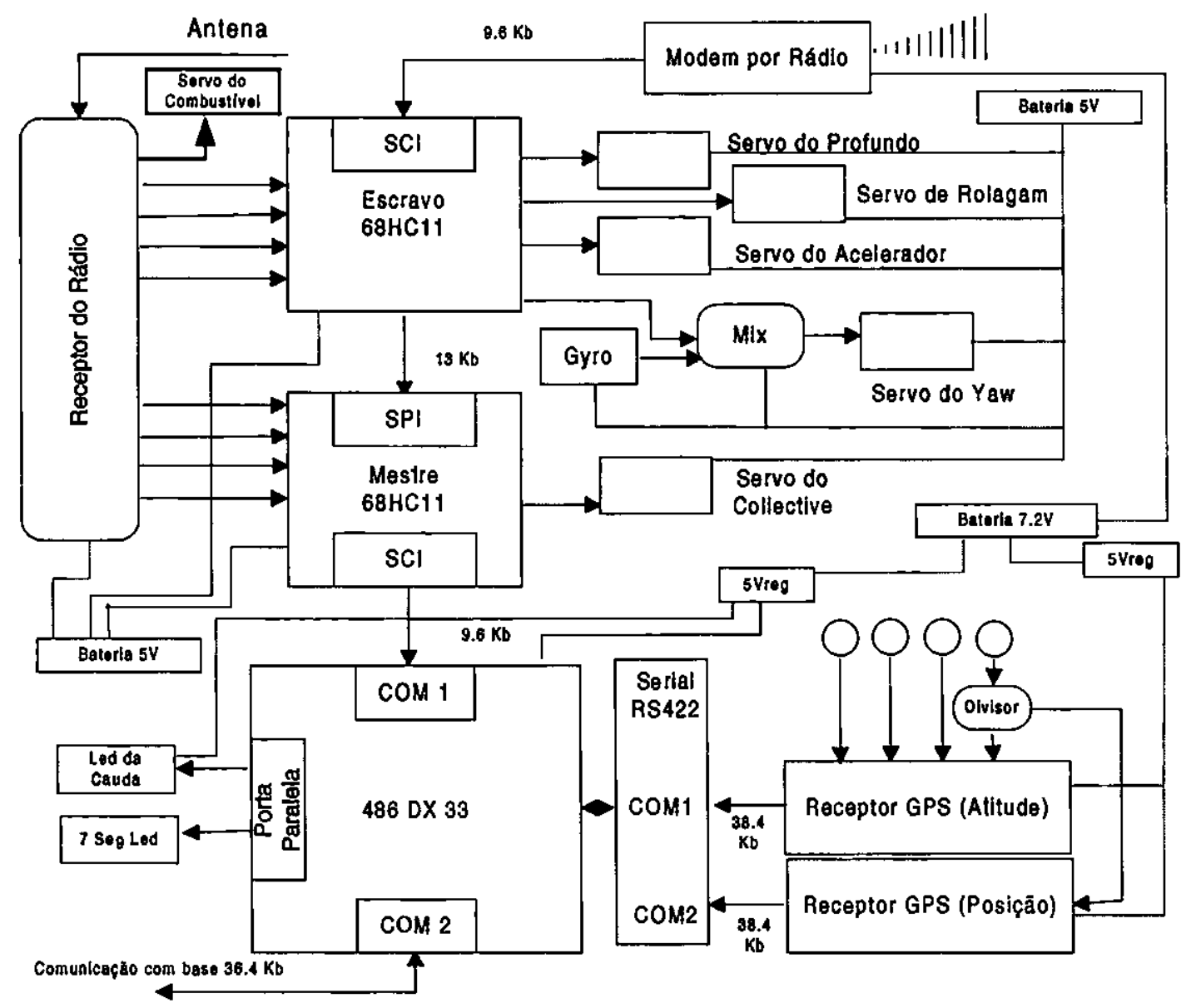

Figura 2.14 Diagrama de bloco de funcionamento do UAV de Stanford.

Foi utilizada uma bateria de $5 \mathrm{~V}$ para os controles manuais. Uma segunda bateria de $5 \mathrm{~V}$ foi utilizada para a alimentação dos servomecanismos. Um terceiro grupo de baterias, consistindo de dois subgrupos de 6 e 10 células, gerando um total de $7.2 \mathrm{~V}$, foi utilizado para alimentar o computador 486, o modem por rádio, as câmeras, o receptor GPS e outros equipamentos associados aos controles. 


\subsubsection{Universidade de Michigan}

\subsubsection{HoverBot}

Este projeto está sendo desenvolvido pela Universidade de Michigan pelo Departamento de Engenharia Mecânica e Mecânica Aplicada. Segundo Boresnstein [BOR99], o objetivo deste projeto é o desenvolvimento de uma plataforma suspensa que seja autônoma ou semi-autônoma, capaz de decolar e pousar na vertical. Vários institutos estão pesquisando aeronaves autônomas que decolem e pousem na vertical, baseadas em modelos comerciais disponíveis, como é o caso dos helicópteros. Contudo, a diferenciação deste projeto se dá por dois elementos: o HoverBot usa quatro rotores e quatro motores elétricos. Segundo Boresnstein, isto torna fácil o seu controle, torna o sistema silencioso e até mesmo adequado para aplicações em lugares fechados. A idéia de utilizar quatro rotores não é nova. A história mostra várias tentativas de implementar este projeto (as primeiras tentativas datam de 1922 [BOR99]). As aplicações especiais, para o HoverBot, são na inspeção e supervisão de áreas com equipamento nuclear.

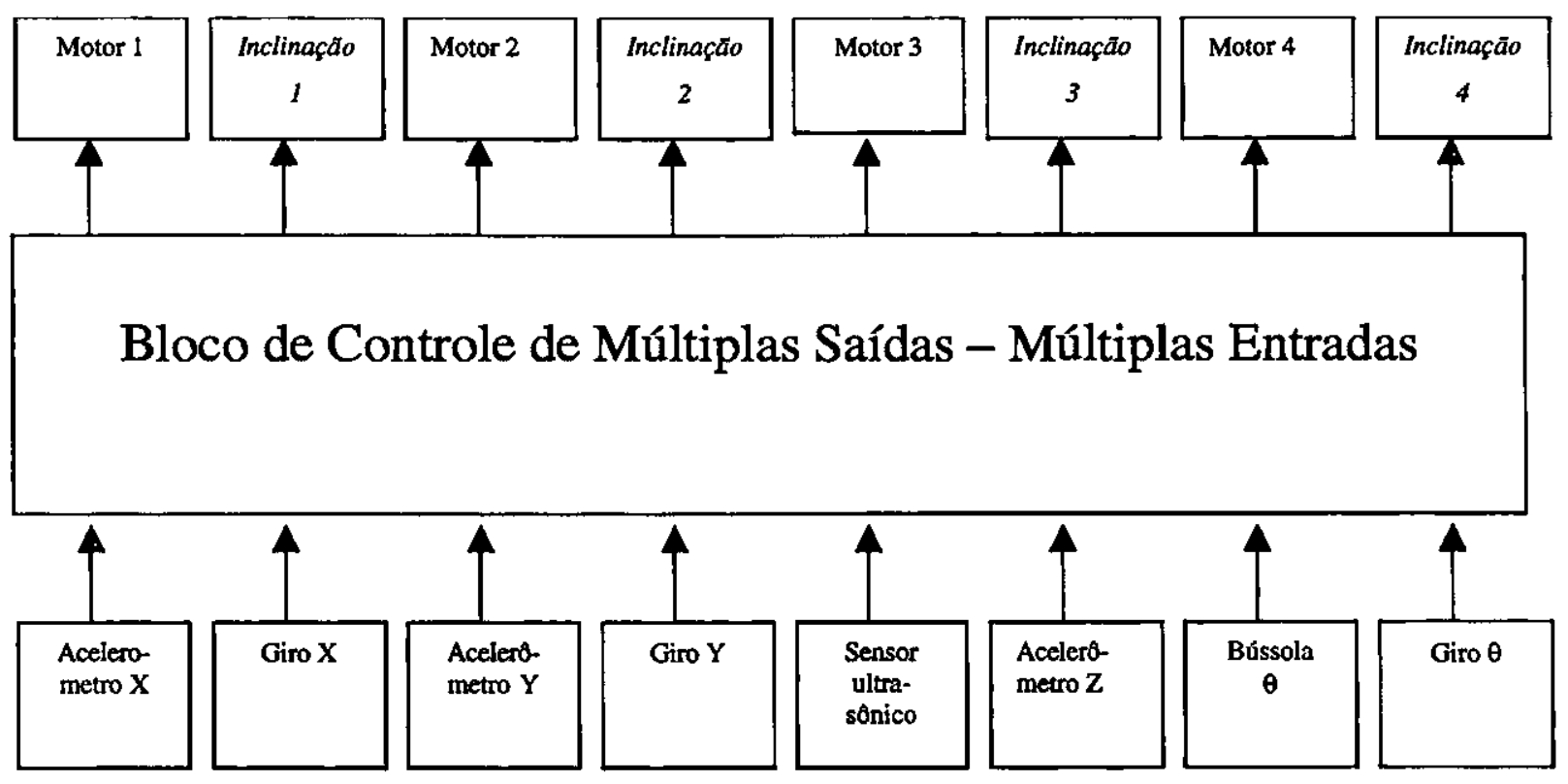

Figura 2.15 Sistema de controle de entrada e saída do HoverBot.

Para controle do HoverBot foram propostos oito diferentes sensores, como mostrado na figura 2.15. Boresnstein propôs dois sistemas primários para estabilizar e controlar a aeronave. Os sensores instalados devem medir a taxa de rotação em volta dos três eixos e enviar tais informações rapidamente para unidade de processamento de dados. Para controlar o HoverBot (como por exemplo mantê-lo suspenso no ar ou para movê-lo), foram usados três acelerômetros. 

, , c. sensores ultra-sônicos de altitude e de bússola também foram adicionados. $O$ sensor ultra-sônico fornece a altura com uma precisão de milímetros [BOR99].

O HoverBot utiliza este sensor nos vôos próximos à superfície e no processo de pouso. Os sinais dos oito sensores são constantemente lidos por uma unidade de controle central, denominada de MEMS (Múltiplas Entradas e Múltiplas Saídas - figura 2.15). O MEMS calcula o sinal para oito saídas: aceleração de quatro motores e o ângulo de inclinação das quatro pás. Para realizar o controle completo e a estabilização do Hoverbot, cada saída é afetada pelas oito entradas.

O HoverBot ainda é um protótipo. Segundo os relatórios de Boresnstein, a principal meta é fazer com que a aeronave se estabilize no ar, através da unidade MEMS, que realiza os cálculos de compensação no momento em que a aeronave faz algum movimento, nos três eixos, em função de turbulência ou movimentos bruscos.

\subsubsection{UAV}

A Universidade de Michigan, através do departamento de Engenharia Aeroespacial mantém um outro programa de UAV com o objetivo de criar uma bancada de testes para pesquisa e demonstração de sistemas UAV autônomos de baixo custo [UNI99]. Os itens sob pesquisa são os seguintes:

- Detecção, isolação e recuperação de falhas no sistema de navegação;

- Configuração e adaptação dos controles do vôo;

- Algoritmo de planejamento de missões automáticas e trajetórias.

O UAV selecionado para o projeto foi um avião com um sistema que pode operar em três modos: no primeiro modo ele é pilotado remotamente, atuando os sistemas de teste, identificação, deteç̧ão e isolação de falhas; no segundo o vôo é assistido por computador e os controles de superfície são misturados; no terceiro, o vôo é completamente autônomo, atuando os sistemas de recuperação de falhas e planejamento de trajetória.

A aeronave mostrada na figura 2.16 utiliza tecnologia de $\mathrm{R} / \mathrm{C}$ padrão, com carga útil de $7,5 \mathrm{~kg}$. O avião está equipado com um motor de 2 cilindros e $4,75 \mathrm{hp}$ de potência, pesa $27 \mathrm{~kg}$ e mede $330 \mathrm{~cm}$ de asa. Possui os seguintes sensores: acelerômetros, bússola e três giroscópios. 
Existem também, no avião, sensores que medem a velocidade do ar, o ângulo de ataque e o sideslip, todos ligados ao computador de bordo.

Dois computadores estão a bordo da aeronave: um 486 e um Pentium de $133 \mathrm{MHz}$. Eles executam o sistema operacional QNX, utilizado para aplicações em tempo real. Os receptores GPS e DGPS estão ligados no Pentium e o uplink e downlink são realizados pelo mesmo, a $115 \mathrm{Kbps}$, através de um modem por rádio.

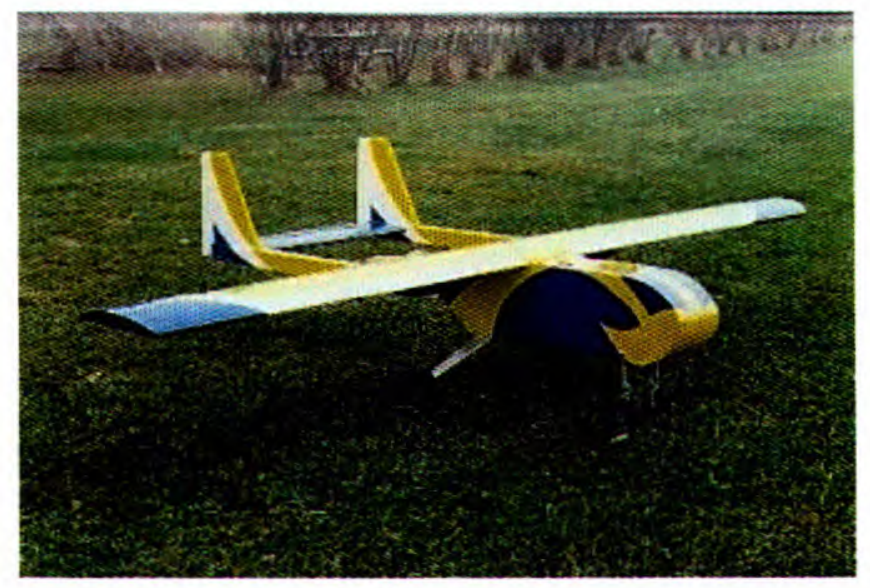

Figura 2.16 O avião utilizado no projeto da Universidade de Michigan.

\subsubsection{Universidade de Campinas}

O Projeto AURORA (Autonomous Unmanned Remote Monitoring Robotic Airship) está sendo desenvolvido pelo CTI (Centro Tecnológico de Informática) em Campinas, através do Laboratório de Robótica e Visão Computacional, Instituto de Automação e a LTA Brasil Ltda. Esse projeto UAV foi direcionado para um balão. O modelo selecionado foi o AS800 da Airships e é mostrado na figura 2.7. Segundo Elfes [ELF98], o objetivo do AURORA é voltado diretamente para questões ambientais, biodiversidades e monitorização de pesquisas climáticas. Devido ao tamanho do dirigível e a sua baixa velocidade, ele está excluído de missões com perfil militar sendo, entretanto, excelente em missões ambientais, já que o mesmo é capaz de levantar e pousar na vertical, sem causar ruídos, podendo, ainda, ficar suspenso no ar. A meta do projeto AURORA é o desenvolvimento de um robô dirigível com um nível de autonomia significativo durante todas as fases de sua operação. Isso inclui a habilidade para realizar missões, navegação automática, diagnóstico de falhas e sua recuperação, avaliação em tempo real dos sensores e replanejamento das tarefas.

O processo de construção e aprimoramento do projeto AURORA foi divido em três 
fases, conforme a tabela 2:

Tabela 2 Etapas do projeto AURORA.

\begin{tabular}{|l|c|c|c|}
\hline & & & \\
\hline Auração missão típica (h) & $1-2$ & 8 & $>24$ \\
\hline Distância típica (km) & $1-10$ & $10-50$ & $>100$ \\
\hline Capacidade de Carga útil (kg) & 10 & 50 & $>100$ \\
\hline
\end{tabular}

Atualmente, a equipe de Elfes está desenvolvendo o AURORA I. Os seus subsistemas físicos são: o dirigível, os controles de bordo e o subsistema de navegação, incluindo sensores internos, hardware e software, o subsistema de comunicação, os sensores diagnósticos e a estação móvel.

Conforme dito anteriormente, o modelo adotado pela equipe Elfes foi o AS800, um modelo não-rígido, com $9 \mathrm{~m}$ de comprimento, $3 \mathrm{~m}$ de diâmetro e $30 \mathrm{~m}^{3}$ de capacidade volumétrica. O dirigível é equipado com dois motores no lado da gôndola e quatro controles de superfície na popa, organizados em ' $\mathrm{X}$ '. Sua capacidade de carga útil é de $10 \mathrm{~kg}$ ao nível do mar.

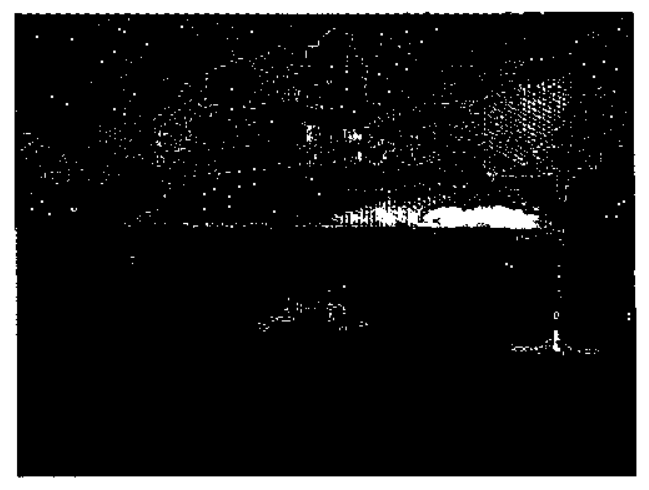

Figura 2.17 Dirigivel AS800.

O hardware do dirigível consiste em um computador de bordo, um microprocessador e sensores internos. $\mathrm{O}$ software foi realizado utilizando o conceito de arquitetura em três camadas.

Os sensores internos da aeronave são: bússola, acelerômetro, inclinômetro, giroscópio e um receptor GPS. Câmeras de vídeo foram montadas na gôndola do dirigível para fornecer imagens aéreas ao operador, servindo para a navegação visual. Uma bússola, um inclinômetro e um receptor GPS são diretamente conectados a um computador PC 104. Todos os controles de 
navegação e sensores (velocidade do motor, altitude, sensor de ângulo de ataque, velocidade do vento, acelerômetros, combustível, nível de carga da bateria e temperatura de motor) estão conectados ao PC e os atuadores (motores e controles de superfície) são conectados ao microprocessador. A figura 2.18 mostra uma visão geral do AURORA.

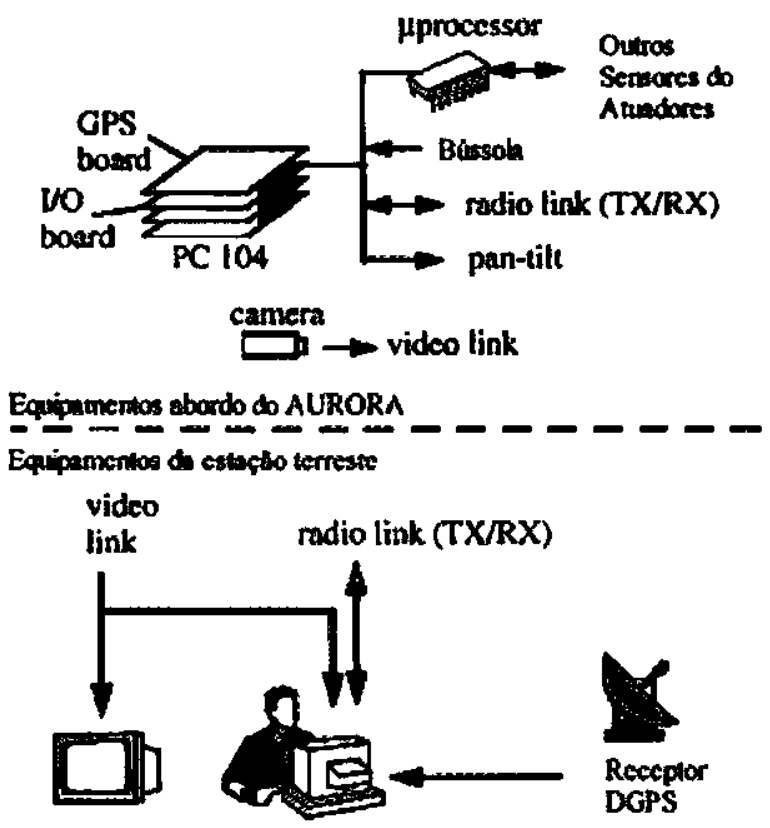

Figura 2.18 Visão geral do hardware do AURORA.

Como sistema operacional, foi escolhido o Linux com um kernel reduzido. A complexidade dos sistemas robôs requer alta interatividade e foram utilizados múltiplos threads para habilitar algumas funções e desabilitar outras, de forma independente. Elfes usou a Arquitetura de Controle de Tarefas [ELF98] por lhe dar uma estrutura conveniente para manipular múltiplos sistemas, dentro de um ambiente distribuído.

A interface homem-máquina fornece a comunicação e a visualização dos instrumentos a bordo do dirigível. Como parte da interface, foi desenvolvido um simulador do dirigível, com base em um modelo físico permitindo a realização do teste de vôo, decolagem e pouso através da Intemet. Na figura 2.19 é mostrada a interface do simulador. 


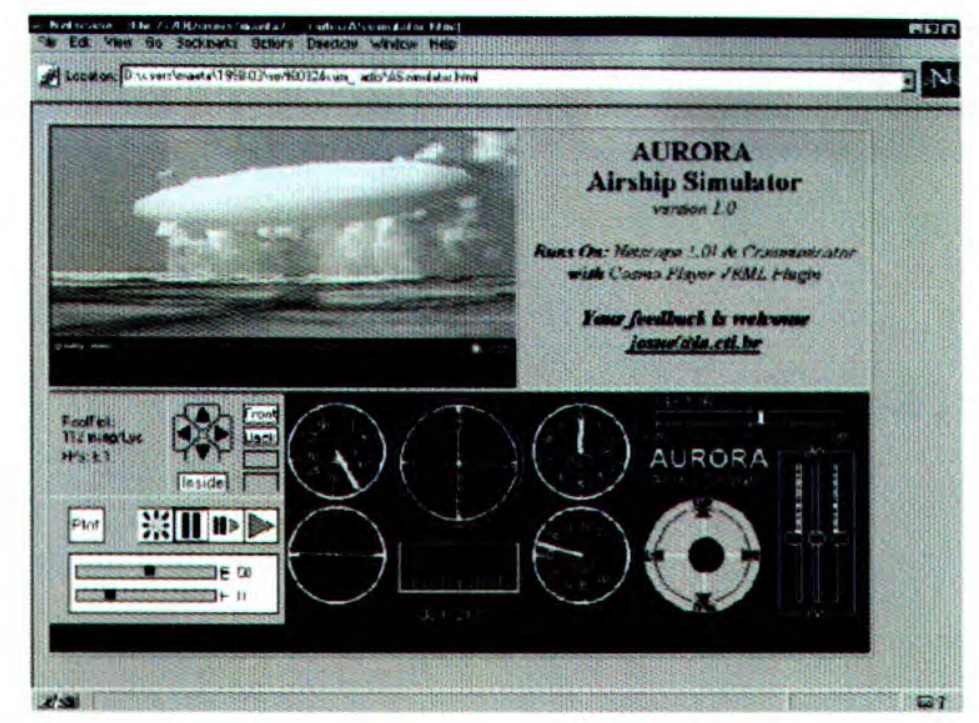

Figura 2.19 Simulador virtual do dirigível AURORA.

\subsubsection{Instituto de Tecnologia Rose-Hulman}

O Instituto de Tecnologia Rose-Hulman desenvolveu um projeto para participar do IARC. O único objetivo deste UAV é a participação no IARC. O modelo selecionado para o ano de 1999 foi um modelo de helicóptero comercial Bergen mostrado na figura 2.20. Ele foi equipado com um motor de dois cilindros com 4 hp de potência.

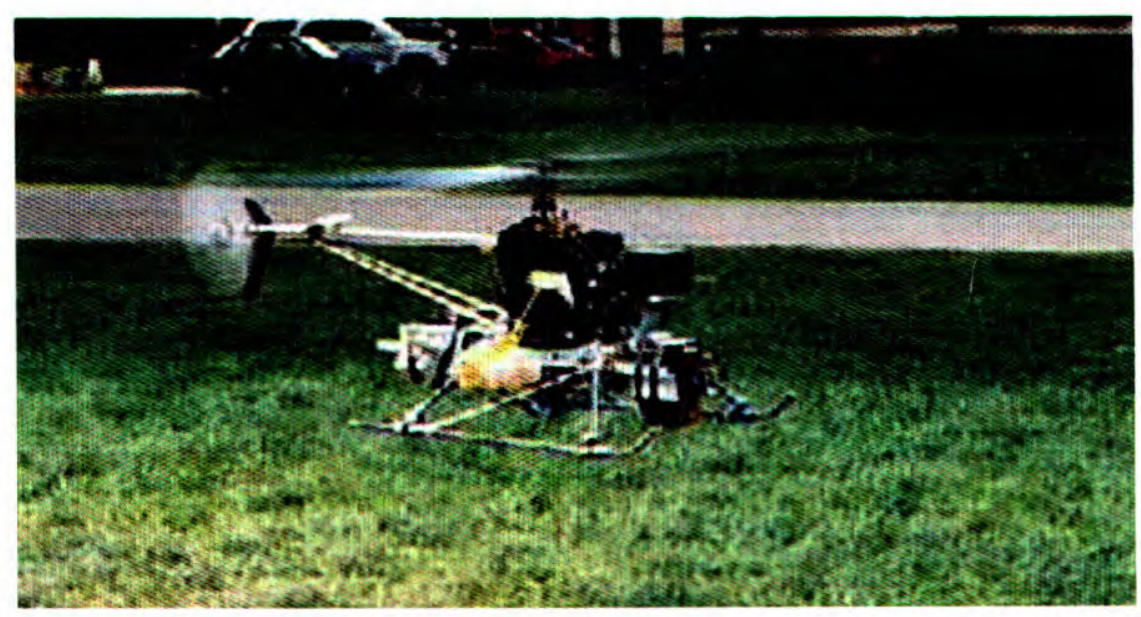

Figura 2.20 O helicóptero do Instituto Rose-Hulman.

Para um maior tempo de vôo, a aeronave foi equipada com dois tanques de gasolina e, com isto, resultando em vôos com duração de aproximadamente 1 hora. Pesando, 7,5 kg, o Bergen é capaz de suspender até $9 \mathrm{~kg}$ de carga útil [ROS99]. 
O helicóptero é equipado com um computador PC-104 Pentium $120 \mathrm{MHz}$, com 4 Mbytes de memória Flash, 32 Mbytes de memória RAM, 2 portas seriais, 1 porta paralela, floppy, IDE, mouse e 2 portas USB, placa de vídeo VGA e entrada para teclado. Esta configuração permitiu o trabalho no helicóptero como se fosse um PC convencional. Para controle dos servomecanismos foi adicionada uma placa PWM (Pulse Width Modulation).

Para determinar a atitude, bem como suas variações, foi utilizado o sistema AHRS (Attitude \& Heading Reference System) da Watson Industries com precisão de $1 / 5$ de grau e taxa de atualização de $60 \mathrm{~Hz}$. O AHRS combina um magnetômetro de fluxo triaxial (para medidas estacionárias) com 3 giroscópios de estado sólido (para medidas dinâmicas). Os dados enviados, por este sensor, são recebidos pelo PC-104 através da porta serial RS232 a 9600 bps.

O receptor GPS determina a posição e a velocidade e o modelo utilizado é da Novatel Millenium RT-2 GPS. Um cartão de DGPS é utilizado para correção da posição. Para maior precisão é utilizada a técnica de CD-GPS (Carrier Phase - Global Positioning System) [CON95].

A comunicação entre a base e a aeronave é feita utilizando um modem por rádio da Hummingbird, operando a $900 \mathrm{MHz}$, com velocidade de $19200 \mathrm{bps}$, potência de $1 \mathrm{~W}$ e alimentação de $5 \mathrm{~V}$.

O UAV está equipado com duas câmeras: Uma colorida com zoom e outra operando na região do infravermelho. Essas câmeras estão ligadas a um multiplexador de dois canais. $\mathrm{O}$ controle da câmera é feito através da porta serial utilizando um PIC16C77. As imagens são transmitidas através de um transmissor de $2.6 \mathrm{GHz}$. A aeronave possui um sensor de temperatura e de RPM. A alimentação do sistema é feita utilizando baterias de Ni-MH de 14V.

O software do sistema foi dividido em dois módulos: Telemetria e Controle. Todo o sistema foi escrito em $\mathrm{C}++$ e é executado no sistema operacional MS-DOS.

O UAV possui ainda um mecanismo de segurança contra falhas do computador realizado por um segundo sistema de rádio controle. Quando a aeronave estiver em situação de perigo o operador pode usar o transmissor 1 (ver figura 2.21) e tomar o controle do helicóptero. No caso de falha, o operador pode ainda utilizar o segundo transmissor e desligar o motor. 


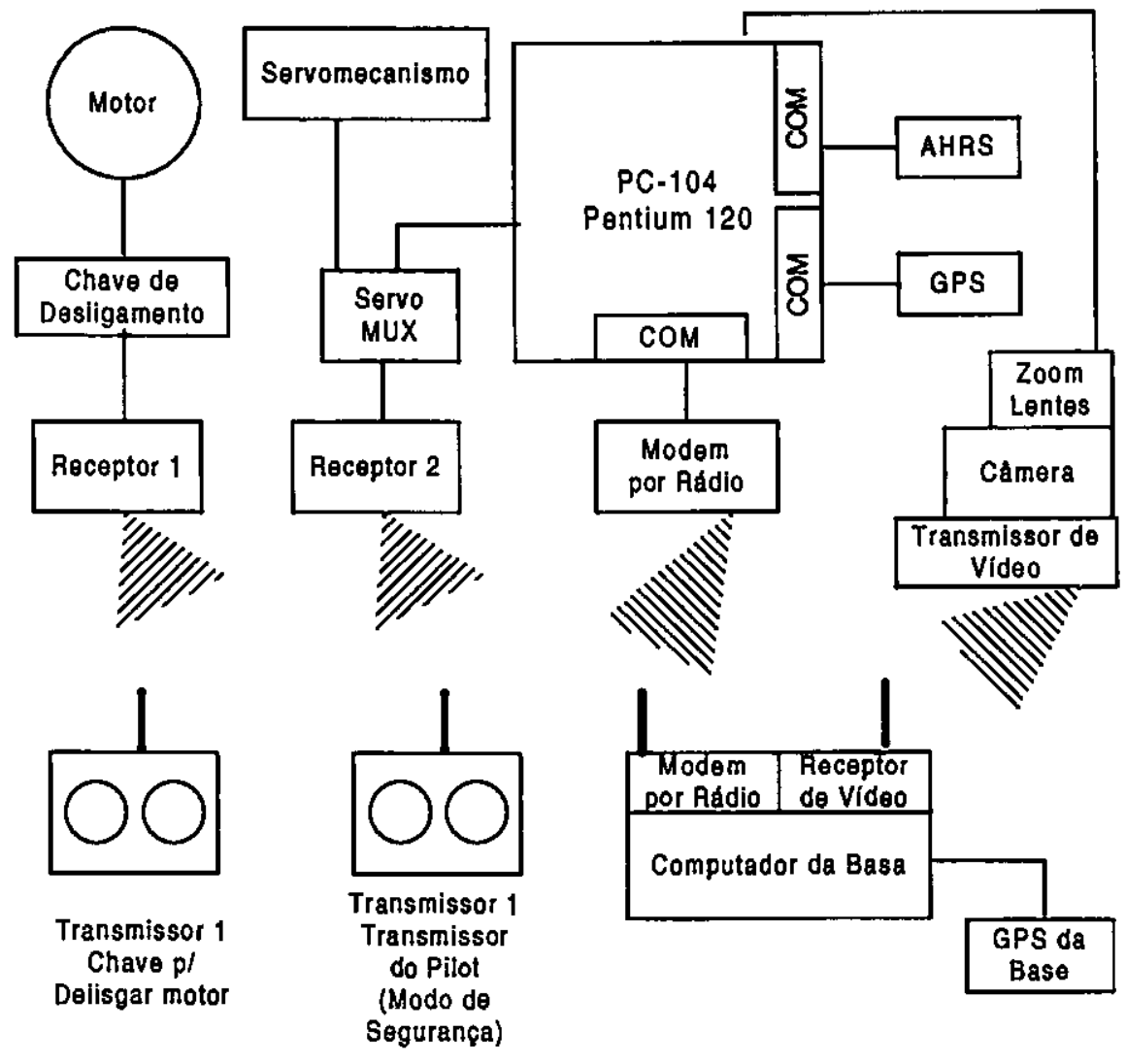

Figura 2.21 Diagrama de bloco do funcionamento do projeto Rose-Hulman.

\subsubsection{Universidade Southern California}

O projeto AVATAR (Autonomous Vehicle Aerial Tracking and Retrieval) foi desenvolvido pela Universidade de Southern California. O AVATAR é o segundo robô construído na linha de projetos de veículos aéreos autônomos auto-suficientes e operando independentemente de qualquer recurso externo. O projeto foi desenvolvido pelo RRL (Robotics Research Laboratory) da universidade [MON99].

O UAV selecionado para o projeto foi um helicóptero Bergen modelo comercial, apresentado na figura 2.22, rádio controlado, equipado com um motor do tipo gasolina, com potência de $2 \mathrm{hp}$. O diâmetro do rotor principal tem cerca de $188 \mathrm{~cm}$ e a carga útil é $12,5 \mathrm{~kg}$.

Na primeira versão do AVATAR, utilizou-se dois processadores 68332 da Motorola, que foram substituídos por uma placa PC-104 486DX4 $133 \mathrm{MHz}, 4$ Mbytes de RAM e 8 Mbytes de disco de estado sólido. O computador 486 executa todo o controle de vôo e o processamento de imagem. 


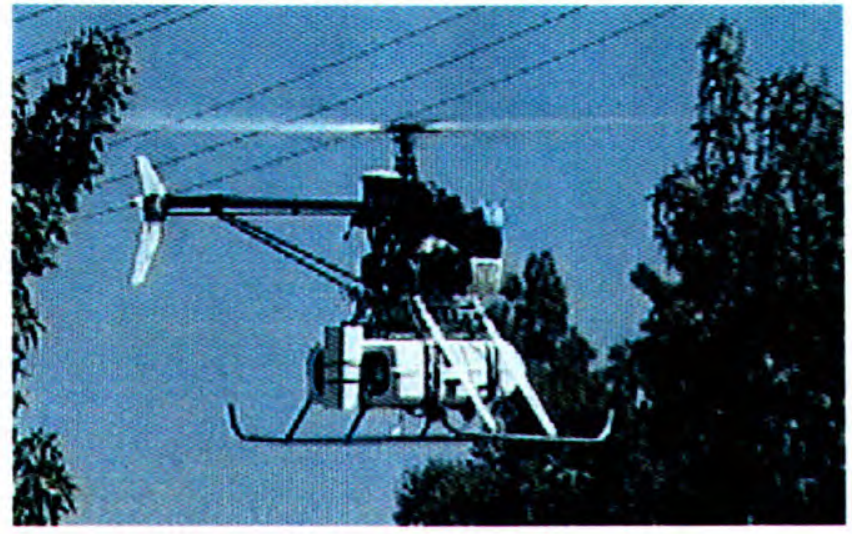

Figura 2.22 O helicóptero do projeto AVATAR.

Um pacote integrado GPS/INS (Inertial Navigation System) equipa o helicóptero. O hardware é composto de um receptor GPS e uma Unidade Medida Inercial (IMU). O GPS/INS fornece posição (latitude, longitude e altitude), velocidade (horizontal e vertical), atitude (arfagem e rolagem), guinada e a taxa de variação da velocidade nos três eixos. O AVATAR I possuía 3 sensor de ultra-som, uma bússola e um sensor de RPM. Na segunda versão do AVATAR, foram substituídos os dois sensores de ultra-som e a bússola pelo GPS/INS. Apenas um sensor de ultra-som e o sensor de RPM foram mantidos.

Para controlar os servomecanismos é utilizada uma placa PWM. O GPS/INS está conectado na porta serial. Um adaptador PC/104 para PCMCIA foi utilizado para conectar uma placa de rede sem fio PCMCIA com largura de banda de $1.8 \mathrm{Mbps}$ entre a base e aeronave. O computador da base recebe as informações da telemetria e envia alguns comandos. A base possui um receptor GPS e os dados de correção do DGPS são enviados através da placa de rede. Um transmissor foi montado dentro do helicóptero para fornecer imagens ao vivo do AVATAR em um monitor específico para esta função. A figura 2.23 mostra detalhes de como estão montados os componentes de hardware do projeto AVATAR.

O software de controle de vôo foi programado utilizando a linguagem $\mathrm{C} / \mathrm{C}++\mathrm{e}$ assembly Intel. O sistema operacional utilizado é o QNX versão comercial. O QNX é armazenado na memória de estado sólido.

O sistema de distribuição de energia é composto de vários conversores DC/DC fornecendo $+5 \mathrm{~V},+12 \mathrm{~V}$ e $-12 \mathrm{~V}$ para os circuitos eletrônicos. O GPS/INS e o PC/104 requerem $+24 \mathrm{~V}$, provenientes de outro conversor. A alimentação desses conversores é feita utilizando baterias de Lítio íon. Os servomecanismos e receptores são alimentados por baterias de hidreto metálico. 


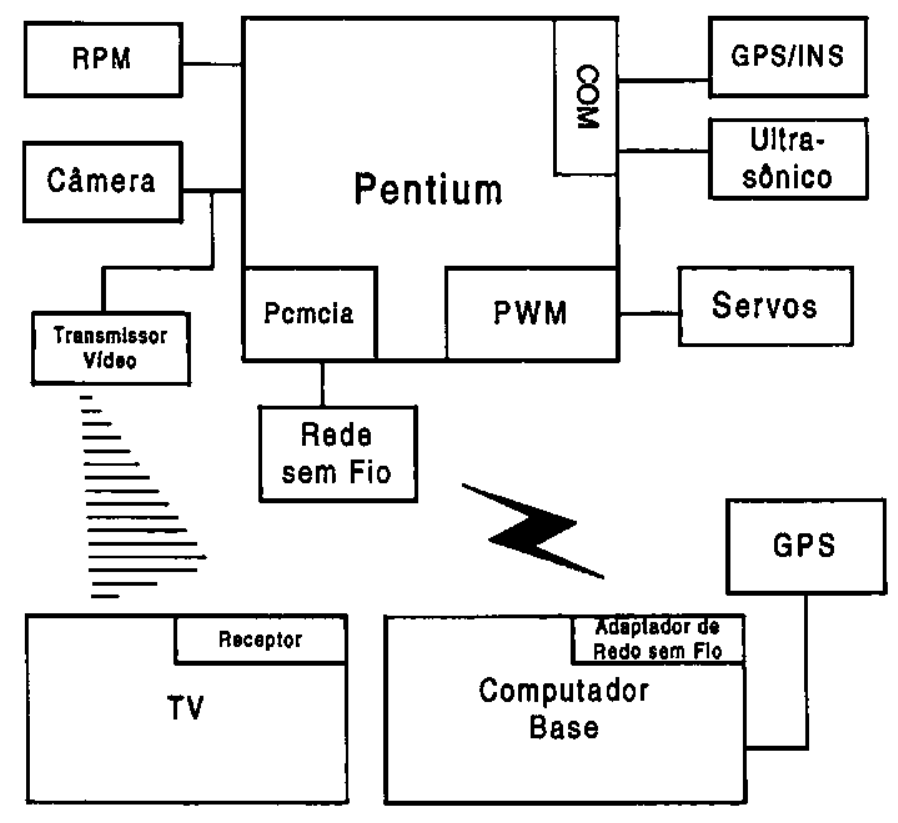

Figura 2.23 Diagrama de blocos do projeto AVATAR.

\subsubsection{Space Grant College}

O projeto AIM foi desenvolvido por Sam Siewert [SIE99] e Wes Bradley do Colorado Space Grant College e é considerado um sistema semi-autônomo. O foco central do AIM é o de fornecer uma plataforma de testes para validação de sistemas que realizam missões com pouca ou nenhuma interferência humana. $O$ projeto do UAV foi direcionado para um dirigível equipado com dois motores nas laterais da aeronave, conforme mostra a figura 2.24 .
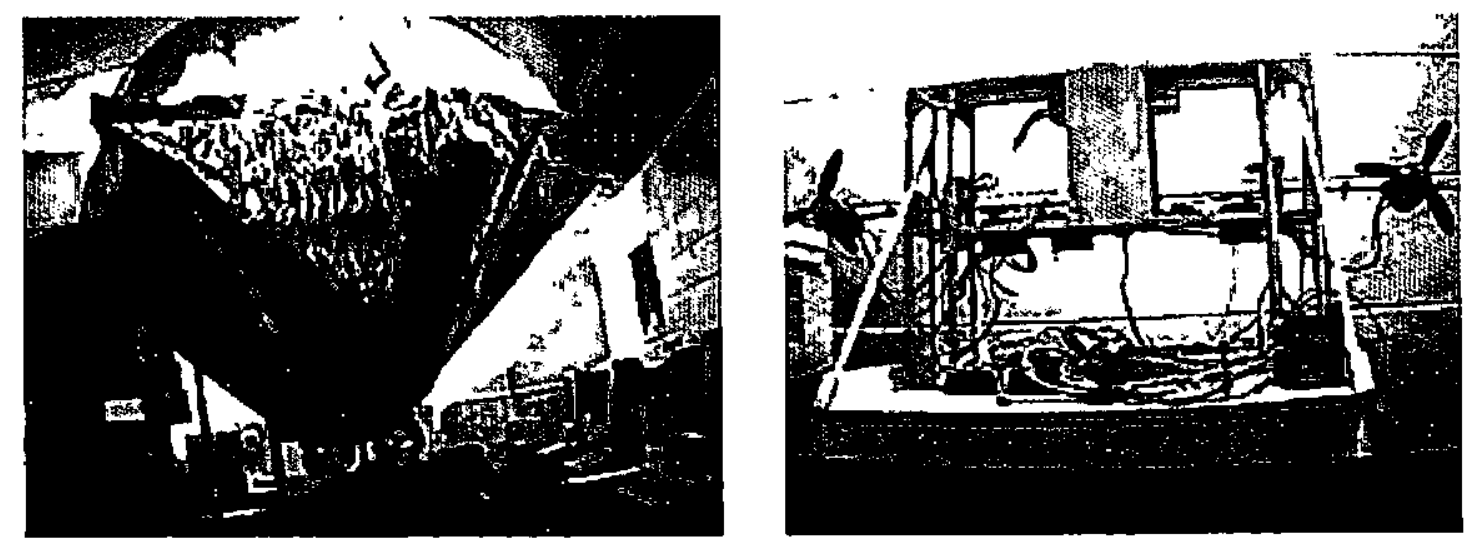

Figura 2.24 O balão e ao lado o motor e o computador do projeto AIM.

O segundo protótipo está equipado com um computador 486, um disco rígido de 80 Mbytes e um microcontrolador $68 \mathrm{H} 11$ da Motorola, que coleta os dados dos sensores e realiza a 
comunicação com o computador 486 a bordo da aeronave. A comunicação entre o UAV e o computador laptop em solo é feita utilizando um par de adaptadores de rede por rádio freqüência PCMCIA. Dois sensores de rotação foram instalados para medir a velocidade dos motores. $O$ dirigível está equipado com uma QuikCam, que transmite as informações para o laptop. Já existe um projeto para o protótipo 3 do AIM, que será equipado com dois microcontroladores $68 \mathrm{H} 11$, uma bússola digital, sensores ultra-sônicos e controle do gás hélio.

$\mathrm{O}$ esquemático de funcionamento do protótipo 3 é apresentado na figura 2.25 . $\mathrm{O}$ computador 486 a bordo executa o sistema operacional Linux, que realiza o controle dos sensores através de programas escritos em $\mathrm{C}$ com a utilização de múltiplos threads. O protótipo 1 e 2 , segundo Siewert, serviu apenas para demonstrar a viabilidade do sistema.

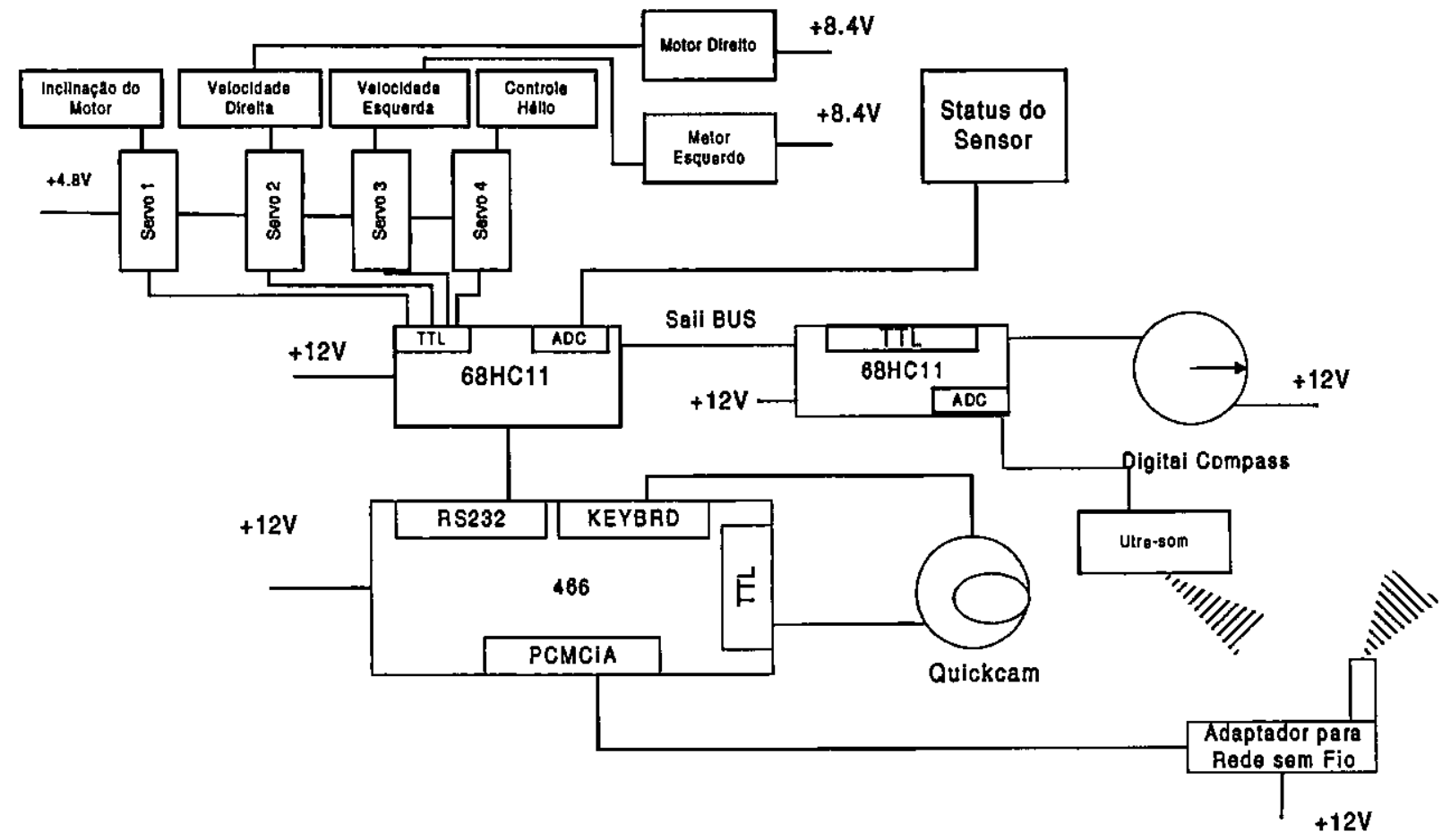

Figura 2.25 Esquemático de funcionamento do AIM 3.

\subsubsection{Massachusetts Institute of Technology}

O projeto Drapper está sendo desenvolvido por Paul DeBitetto [DEB97] e Bill Hall no MIT (The Massachusetts Institute of Technology) através do Laboratório Drapper. Algumas das possibilidades mencionadas em suas páginas WWW para o uso desse UAV são: mapeamento autônomo, agrimensura, salvamento, entrega e recuperação de pacotes e vigilância de áreas remotas. A aeronave escolhida foi um helicóptero comercial da Bergen. As características físicas 
deste helicóptero já foram citadas anteriormente. A figura 2.26 mostra o helicóptero utilizado.

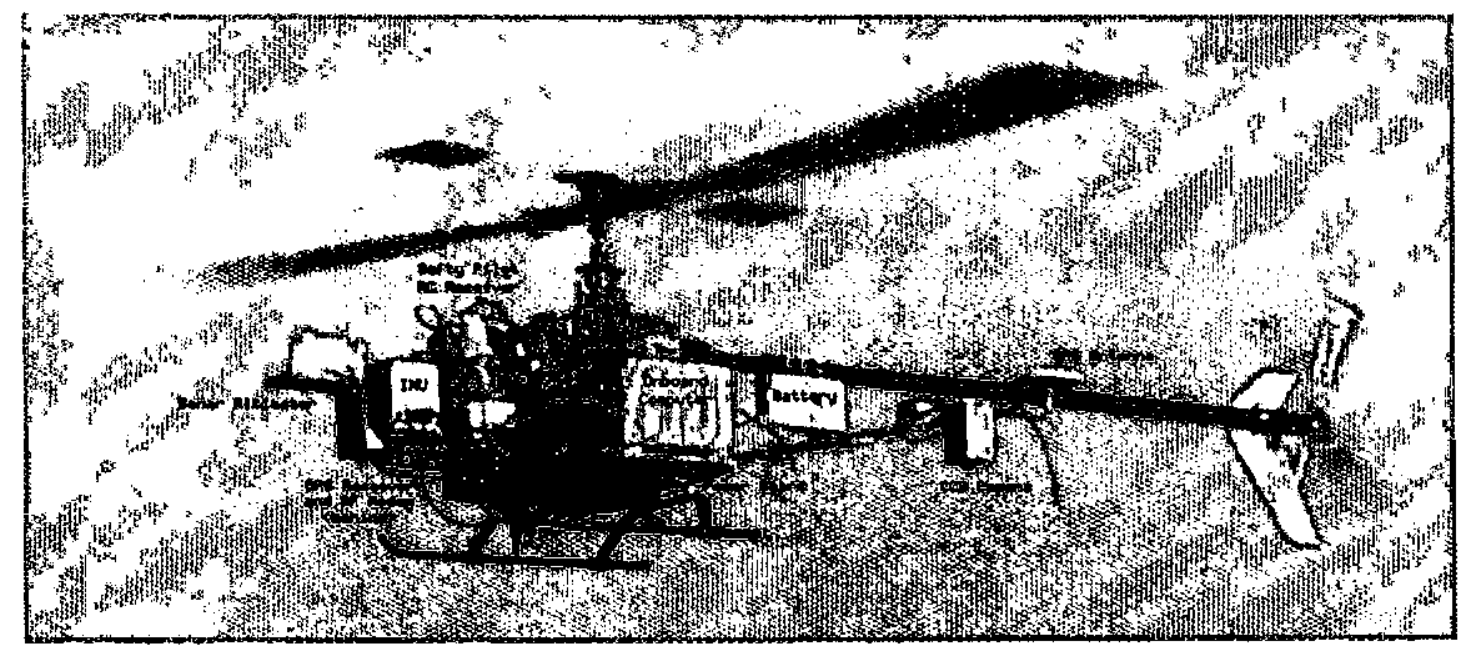

Figura 2.26 O helicóptero do projeto Drapper.

A aeronave está equipada com um computador PC-104 486DX $100 \mathrm{MHz}$. Para obter a localização da aeronave, é utilizado um receptor DGPS da Novatel [NOV00] que se comunica com o PC-104 através de uma porta serial. A estação de base, um Pentium 266 com 256 Mbytes de memória, possui um DGPS que transmite as informações de correção para a aeronave através de um modem por rádio. Os dados para o sistema de navegação são coletados pelo kit DGS fornecido pelas indústrias KVH. O mesmo é composto de um altímetro, uma bússola, dois giroscópios e um inclinômetro. O DGS está conectado na PC-104 através de uma porta RS-422 (figura 2.27). Para controlar os servomecanismos, utiliza-se um microcontrolador $68 \mathrm{HC} 12 \mathrm{da}$ Motorola, que recebe comandos enviados pelo PC-104. O receptor do equipamento de rádio controle sofreu algumas modificações para se adequar ao $68 \mathrm{HC} 12$. Um canal do receptor foi reservado para cortar a aceleração do motor.

O transmissor de vídeo, a bordo da aeronave, transmite as informações para a estação de solo. O software da estação foi escrito em Visual C++ usando MFC (Microsoft Fundation Class). O sistema de navegação foi escrito em C e é executado sobre o sistema operacional QNX (está sendo migrado para Linux, utilizando memória compartilhada). As imagens capturadas pela aeronave são processadas pelo microcomputador da estação e em seguida são enviados os resultados do processamento para a aeronave através do modem por rádio. 


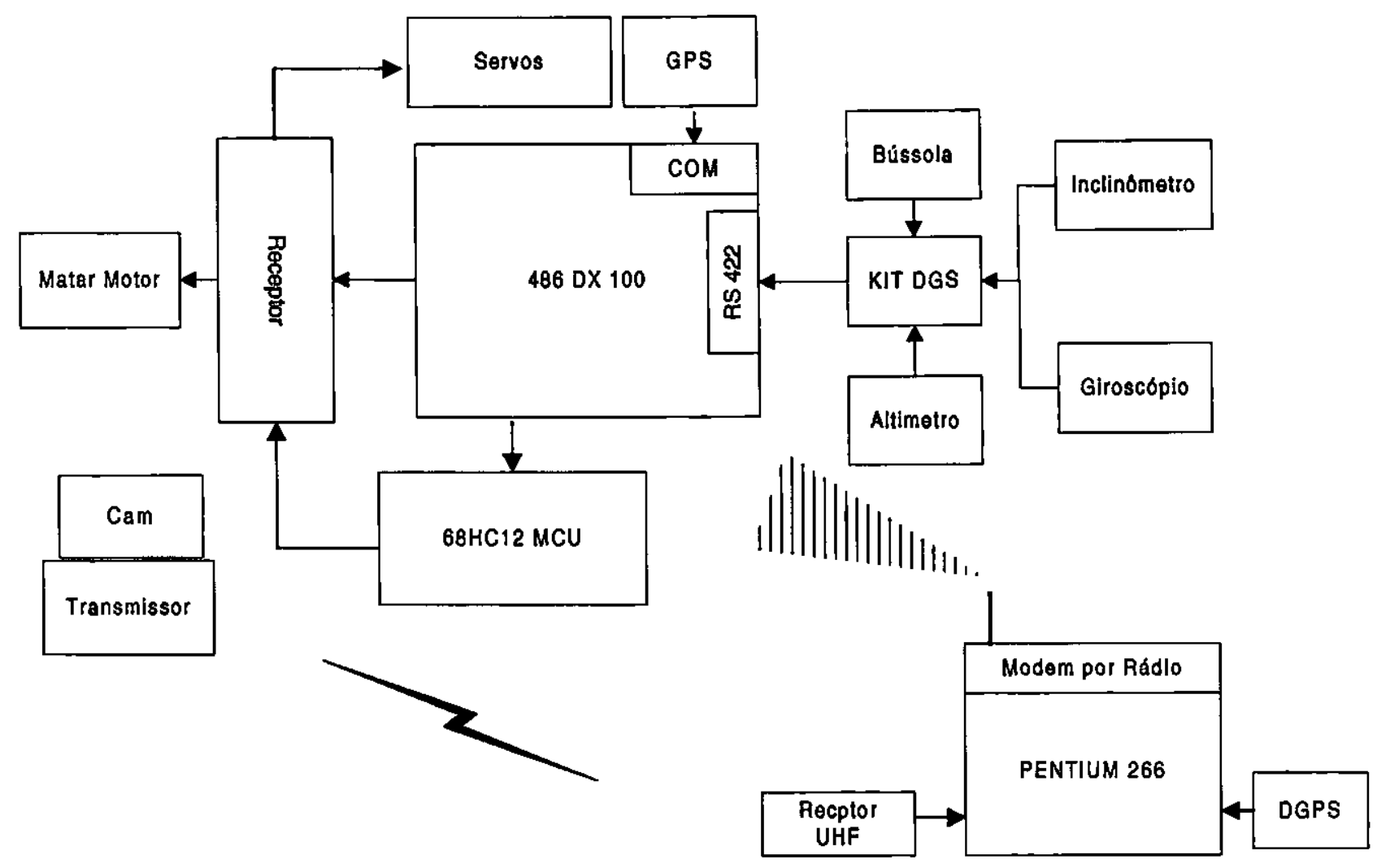

Figura 2.27 Diagrama de bloco do funcionamento do projeto de MIT.

\subsubsection{Australian Bureau of Meteorology}

O projeto Aerosonde foi desenvolvido em parceria com o Environment System and Services, em Melbourne, e o Australian Bureau of Meteorology. Entre os seus responsáveis, incluem-se o U.S. Office of Naval Research, o National Oceanic and Atmospheric Administration e o U.S. Department of Energy. O objetivo deste projeto está centrado na construção de um avião robô, para monitorização ambiental de longo alcance (ver figura 2.28). Ele pode ser adaptado para outras aplicações que exigem pequena carta útil, como por exemplo, para estudos geomagnéticos [AES99]. O seu desenvolvimento foi centrado no reconhecimento meteorológico e ambiental do oceano investigando furacões e tempestades. Recentemente essa aeronave entrou para a história quando cruzou o oceano atlântico da Austrália para o E.U.A, passando por furacões, sem qualquer intervenção humana.

O projeto Aerosonde foi divido em duas fases. A primeira, operacional, mostrou a viabilidade do projeto e as adaptações necessárias para a fase dois, que possibilita vôos de longa duração a grandes altitudes. A aeronave da primeira fase pesa $15 \mathrm{~kg}$ e mede 3 metros de asa, medida essa mantida na segunda fase. $O$ motor utilizado é de $20 \mathrm{~cm}^{3}$, proporcionando uma 
velocidade de vôo de 20 a $30 \mathrm{~m} / \mathrm{s}$. A aeronave possui um alcance superior a $3.000 \mathrm{~km}$ e pode ficar voando por mais de 30 horas a $5.300 \mathrm{~m}$ de altura. Sua carga útil é de até $2 \mathrm{~kg}$. Já na fase II, a aeronave apresenta as seguintes especificações:

- Carga útil de $5 \mathrm{~kg}$;

- Altitude de vôo de $13.000 \mathrm{~m}$;

- Duração do vôo de 3 a 5 dias;

- Motor de 20 a $40 \mathrm{~cm}^{3}$;

- Alcance de $7.000 \mathrm{~km}$.

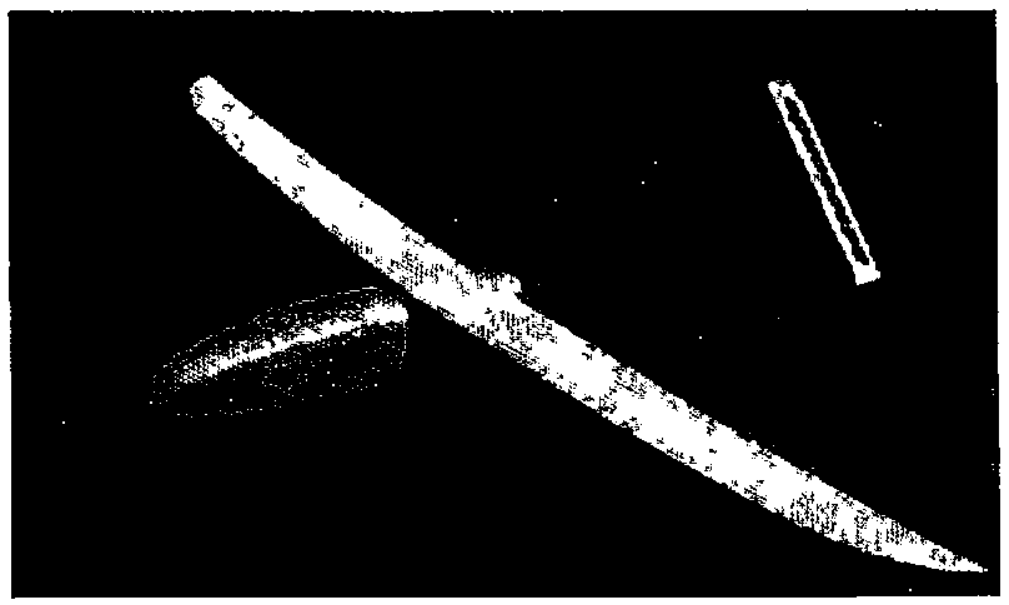

Figura 2.280 avião do projeto Aerosonde.

O Aerosonde é completamente autônomo. É capaz de decolar e pousar, sem qualquer interferência humana. Para a navegação, é utilizado um receptor GPS. Existe um mecanismo para sobrepor os comandos gerados pelo computador de bordo, caso seja necessária a intervenção humana. A aeronave possui os seguintes sensores com o intuito de realizar o monitorização ambiental:

- Velocidade do vento;

- Pressão;

- Altura;

- Temperatura;

- Umidade. 
O Aerosonde faz a comunicação com a estação de solo a 9.600 bps, utilizando um modem por rádio, operando na faixa de UHF com raio máximo de alcance de $150 \mathrm{~km}$. A estação de solo móvel está ligada a uma estação fixa em Melbourne através de telefonia por satélite e a estação fixa pode comandar a aeronave.

\subsubsection{Universidade Sydney}

O projeto Brumby está sendo desenvolvido pela Universidade de Sydney na Austrália. O objetivo inicial era o de fornecer uma plataforma de pesquisa para várias atividades, tais como:

- Pesquisas de aerodinâmica em túnel de vento;

- Modelagem do desempenho de motores/hélice e características da estabilidade da aeronave;

- Simulação para validação dos sistemas de controle de vôo;

- Otimização de trajetórias;

- Utilização do receptor GPS para determinar a atitude da aeronave;

- Decolagem autônoma e recuperação do UAV.

A aeronave escolhida para o projeto foi um avião com asas em delta, mostrado na figura 2.29. Este modelo foi construído no Departamento de Engenharia Aeronáutica e possui uma construção modular extremamente simples, de baixo custo e de fácil manutenção [WON99a]. O avião foi projetado com 2,58 $\mathrm{m}$ de envergadura, com a fuselagem medindo $1,97 \mathrm{~m}$ e pesando $17 \mathrm{~kg}$. Seus equipamentos para vôo autônomo pesam $2 \mathrm{~kg}$. O motor utilizado é a gasolina, marca Zenoah com $74 \mathrm{~cm}^{3}$ e $7 \mathrm{hp}$ de potência. Este avião é capaz de voar à velocidade de 100 nós, com duração do vôo entre trinta e sessenta minutos. Sua carga útil é de $6 \mathrm{~kg}$, quando pilotado remotamente, ou $4 \mathrm{~kg}$ quando pilotado autonomamente. Esta aeronave está equipada com baterias de 200 watts para a alimentação da eletrônica de bordo.

Os sensores que equipam a aeronave para manter a sua estabilidade são:

- Um conjunto com 3 giroscópios e 3 acelerômetros nos três eixos;

- Uma sonda de ângulo de ataque, ângulo de sideslip e velocidade do ar;

- Sensor de atitude; 
- Um receptor GPS (sistema c/ 4 antenas) para determinar a velocidade, a posição e a atitude.

O computador que realiza a coleta dos dados é um PC-104 (Pentium 90MHz), executando um sistema operacional de tempo real (não especificado na documentação). $\mathrm{O}$ computador de solo recebe os dados enviados pela aeronave através de um modem por rádio. Os dados também são armazenados a bordo da aeronave em um disco de estado sólido.

A universidade de Sidney desenvolve outros projetos em paralelo como o Aerial e o KCEXP-3 [WON99b].
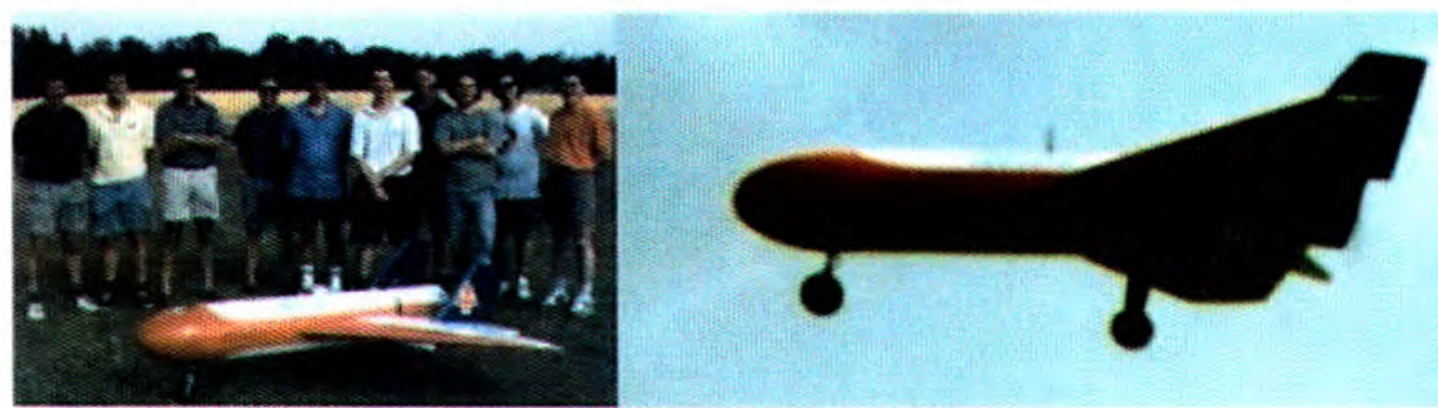

Figura 2.29 O avião do projeto Brumby.

\subsubsection{Swiss Federal Institute of Technology}

O Swiss Federal Institute of Techonology em Zurich, através do ACL (Automatic Control Laboratory), MCL (Measurement and Control Laboratory) criou um UAV para participar do IARC, obtendo o segundo lugar no ano 1996. O modelo selecionado foi um helicóptero comercial mostrado na figura 2.30 , pesando $9 \mathrm{~kg}$. O diâmetro do rotor principal é de $1,8 \mathrm{~m}$ e o total da carga útil é de aproximadamente $7 \mathrm{~kg}$, incluindo equipamentos eletrônicos, baterias, sistemas de segurança e combustível [SWI99].

O sistema de navegação é composto dos seguintes instrumentos:

- Um DPGS para obtenção da posição e velocidade. A margem de erro é de $2 \mathrm{~cm}$;

- Sensor ultra-sônico para determinar a altura;

- IMU (Unidade de Medida Inercial). 

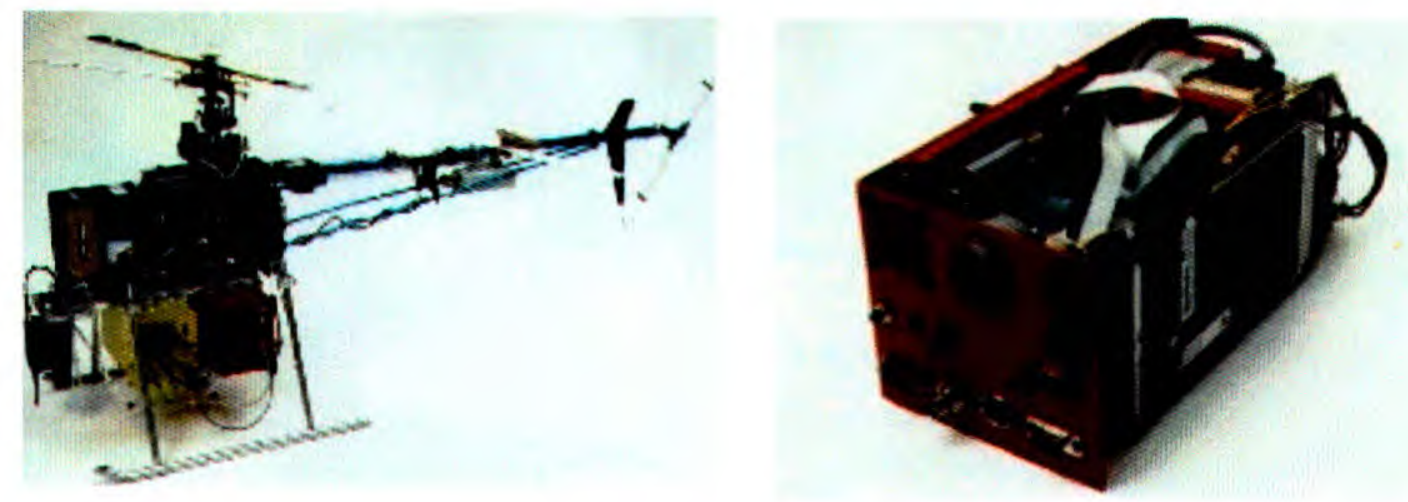

Figura 2.30 O helicóptero e ao lado a caixa de navegação do projeto da Universidade Zurich.

O helicóptero está equipado com uma câmera de vídeo CCD com um processador de sinal integrado à câmera. O computador responsável pela navegação é um PC-104 486DX 100 $\mathrm{MHz}, 4$ Mbytes de memória e uma unidade floppy disk, equipado com um modem por rádio de $115 \mathrm{Kbps}$, colocado em uma caixa preta. Nessa caixa existe uma conexão para monitor e teclado, que são utilizados na carga do software de navegação. No computador da base está conectado um receptor de DGPS. Os dados coletados são enviados através do modem para corrigir a posição da aeronave.

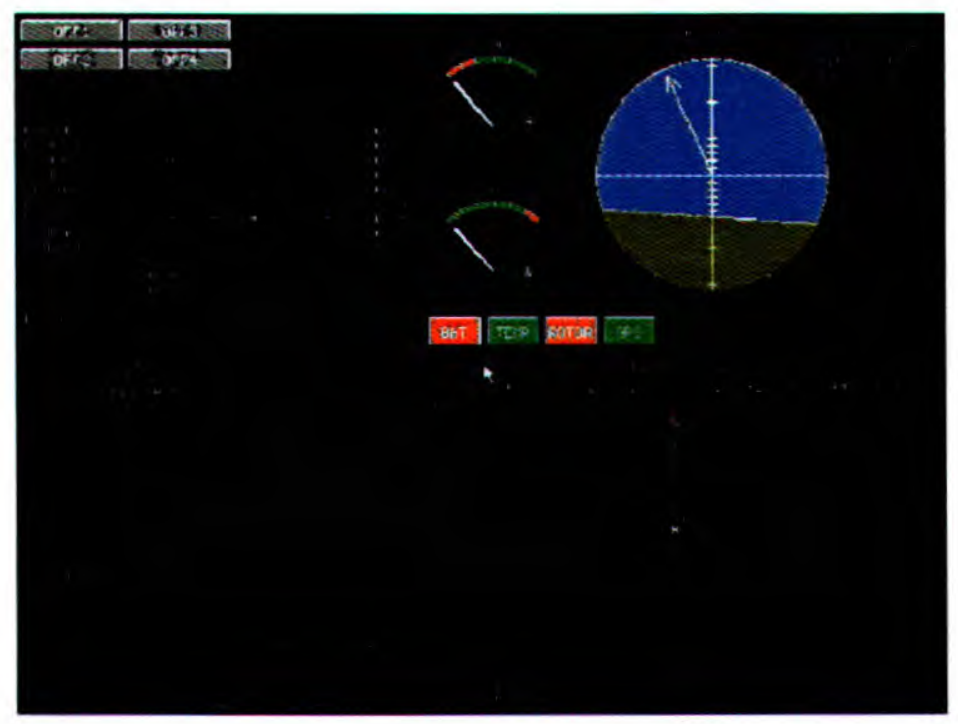

Figura 2.31 Interface do HORLA.

O software de controle de navegação foi escrito em Oberon ${ }^{1}$ [ETH00] e o sistema operacional que é executado no PC-104 é o Oberon. Os dados coletados pelo PC-104 são

\footnotetext{
${ }^{1}$ Oberon é uma agregação de sistema operacional e linguagem. O mesmo é semelhante ao Turbo Pascal.
} 
enviados para um laptop em solo. A figura 2.31 mostra detalhes da interface de visualização dos dados.

\subsection{Considerações sobre os Projetos de Pesquisa Revistos}

Todos os projetos citados têm como objetivo criar um robô aéreo autônomo que seja capaz de realizar suas missões de forma automática podendo efetuar modificações em sua trajetória e recuperar eventuais falhas no sistema. Algumas aeronaves apresentadas anteriormente têm propósitos distintos, como é o caso do projeto AURORA e do projeto Aerosonde que têm como finalidade principal o monitorização ambiental. Já o HOVERBOT é um projeto cujo propósito se destina a aplicações em lugares fechados, como por exemplo, em instalações nucleares. Os projetos que foram citados seguem um certo padrão de evolução. Em um primeiro estágio é validada a viabilidade financeira e tecnológica do projeto para, em estágios subsequientes, serem feitos melhoramentos no desempenho do sistema e no nível de funcionalidade proporcionado pelos mesmos. Isso se traduz no aumento da carga útil, maior autonomia de vôo, melhoramento dos sensores instalados a bordo das aeronaves, entre outros fatores. A tabela 3 mostra um resumo das principais características dos projetos revistos servindo como um meio de comparação entre eles.

É interessante observar que os instrumentos de bordo foram escolhidos em função dos objetivos desejados no projeto. Por exemplo, no ARL Stanford, a bússola, o giroscópio e o sensor ultra-sônico foram substituídos por 2 receptores de GPS. A maioria dos projetos trabalha com microcomputadores do tipo PC-104 para controle e gerenciamento. Para controle dos servomecanismos e a leitura dos sensores são utilizados, na maioria dos casos, microcontroladores da Motorola. Alguns projetos, como o Draper, utilizam uma unidade para navegação inercial onde estão embutidos vários sensores. Assim, os sensores fornecidos por essas unidades serão descritos como instrumentos distintos na tabela 3. 
Tabela 3 Instrumentação a bordo dos projetos UAV revistos.

\begin{tabular}{|c|c|c|c|c|c|c|c|c|c|c|c|c|c|c|}
\hline Projeto & $\begin{array}{l}\text { Tipo de } \\
\text { Aeronave }\end{array}$ & $\begin{array}{l}\text { Tipo } \\
\text { Motor }\end{array}$ & 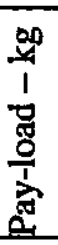 & 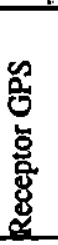 & 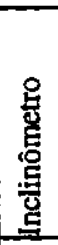 & $\begin{array}{l}\text { 蛋 } \\
\text { 至 } \\
\end{array}$ & $\begin{array}{l}\frac{8}{0} \\
\stackrel{2}{Z} \\
\end{array}$ & 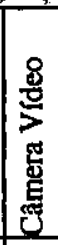 & 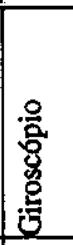 & $\begin{array}{l}\text { 总 } \\
\text { 总 }\end{array}$ & 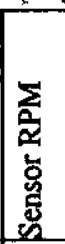 & 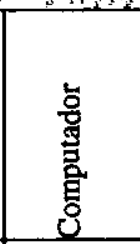 & 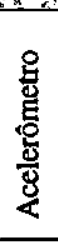 & 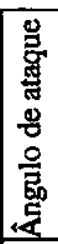 \\
\hline ARL Stanford & Helicóptero & Glow & 11 & 2 & 0 & 0 & 0 & 2 & 0 & 0 & 1 & 486 & 0 & 0 \\
\hline HOVERBOT & Plataforma & Elet. & NI & 0 & 0 & 0 & 1 & 0 & 3 & 1 & 0 & NI & 3 & 0 \\
\hline Michigan (UAV) & Avião & Comb. & 7 & 1 & 0 & 0 & 1 & 1 & 3 & 1 & $\mathrm{NI}$ & Pentium & 1 & 1 \\
\hline AURORA & Dirigível & Elet. & 10 & 1 & 1 & 1 & 1 & 1 & 1 & 1 & 1 & 486 & 1 & 1 \\
\hline AVATAR & Helicóptero & Gás & 12 & 1 & 0 & 1 & 1 & 1 & 1 & 0 & 1 & 486 & 3 & 0 \\
\hline Rose-Hulman & Helić́ptero & Comb. & 9 & 1 & 0 & 1 & 0 & 2 & 3 & 1 & 1 & Pentium & 0 & 0 \\
\hline AIM UAV & Dirigivel & Elet. & NI & 0 & 0 & 0 & 1 & 1 & 0 & 1 & 2 & 486 & 0 & 0 \\
\hline Draper & Helicóptero & Comb. & NI & 1 & 1 & 0 & 1 & 1 & 2 & 1 & NI & 486 & 0 & 0 \\
\hline Aerosonde & Avião & Gas. & 5 & 1 & 0 & 1 & 1 & 0 & NI & 1 & NI & NI & NI & 0 \\
\hline Brumby & Aviāo & Glow & 6 & 1 & 0 & 1 & 0 & 0 & 3 & 0 & 1 & 486 & 3 & 1 \\
\hline Horla & Helicóptero & NI & 7 & 1 & 0 & 1 & 1 & 1 & 1 & $\mathrm{NI}$ & NI & 486 & 0 & 0 \\
\hline
\end{tabular}

\subsection{Considerações Finais}

Neste capítulo foram revistos diversos conceitos envolvidos em um projeto de UAV, incluindo os tipos de aeronaves mais usadas, os elementos básicos que as compõem e a instrumentação necessária para que uma aeronave não tripulada possa realizar vôo não visual autônomo ou remotamente pilotado.

Foi feita uma explanação sobre o protocolo de comunicação desenvolvido no trabalho de mestrado de Souza [SOU99], adotado para o sistema UAV em desenvolvimento. Para isso, foram revistas algumas técnicas e protocolos de enlace de dados.

Os UAVs podem ser explorados em vários segmentos do mercado e de diferentes 
maneiras. No mercado civil, o UAV ainda é pouco utilizado em função da pequena divulgação do que ele é capaz de realizar.

Foram também analisados neste capítulo diversos outros projetos de pesquisa envolvendo UAVs que estão em andamento, procurando-se situar o projeto deste trabalho entre eles. No final do capítulo foi apresentado um quadro comparativo entre os diversos projetos de pesquisa revistos.

No próximo capítulo são definidos o Projeto ARARA e os requisitos funcionais de hardware e software necessários à implementação da fase II. 


\section{Capítulo 3}

\section{Análise de Requisitos do Sistema}

\subsection{Considerações Iniciais}

Este capítulo tem por objetivo descrever os requisitos de hardware e de software relacionados à fase II do Projeto ARARA. Na seção 3.2, são definidos o Projeto ARARA e suas fases. Os requisitos funcionais e não funcionais de hardware são descritos nesta seção. Na seção 3.4, são definidos os requisitos funcionais e não funcionais do software de telemetria. Finalmente, na seção 3.5, são apresentadas as considerações finais deste capítulo.

\subsection{O Projeto ARARA}

O Projeto ARARA - Aeronaves de Reconhecimento Assistidas por Rádio e Autônomas, está centrado no uso de aeronaves em escala reduzida para monitorização. $O$ seu principal objetivo está na substituição das aeronaves convencionais utilizadas na obtenção de fotografias aéreas para monitorização de plantações e áreas sujeitas a problemas ambientais. A aeronave do Projeto ARARA deve apresentar custos de aquisição e manutenção baixos e não deve necessitar uma pessoa especializada para a sua operação.

O projeto está sendo desenvolvido no Departamento de Ciências de Computação e Estatística na Universidade São Paulo, no campus de São Carlos, sob a supervisão do Prof. Dr. Onofre Trindade Jr. O ARARA utiliza na sua construção diversos componentes de aeromodelos, reduzindo o seu custo e facilitando a sua manutenção.

Seguindo uma tendência aplicada a outros projetos semelhantes, o Projeto ARARA foi 
dividido em quatro fases. Os resultados de cada fase representam sistemas com níveis de complexidade e custo crescentes, adequados para diferentes aplicações. Souza [SOU99], elaborou uma classificação dos UAVs em três tipos que foi aplicada na definição do Projeto ARARA.

Fase I: Classificada por Souza como tipo I, a mesma incorpora o mínimo de funcionalidade e apresenta o menor custo com a máxima facilidade de implementação. Nesta fase são utilizados componentes convencionais de aeromodelismo, câmeras fotográficas convencionais ou digitais e câmeras de vídeo para a obtenção de fotografias ou imagens aéreas. Neste tipo de sistema, os vôos são feitos dentro do alcance visual e controlados por equipamentos de rádio-controle convencionais com alcance de aproximadamente $1 \mathrm{~km}$. Esse tipo de sistema é adequado para aplicações onde o vôo da aeronave pode ser controlado de uma estação em terra, da mesma forma praticada com os aeromodelos. Essa etapa já foi concluída por Souza em sua dissertação de mestrado.

Fase II: Classificada como tipo II, esta fase envolve o projeto e a construção de um aeromodelo R/C específico para a aplicação, com uma grande variedade de sensores para o controle do vôo, tais como GPS, giroscópio, bússola, velocidade do vento, altitude, etc. Duas câmeras de vídeo são instaladas a bordo da aeronave, uma na frente e outra apontando para baixo, para transmitir imagens em tempo real para o computador da Estação Base. A câmera instalada na frente da aeronave permite que o piloto possa voar fora do seu alcance visual, enquanto que a câmera voltada para baixo permite que o piloto possa escolher a área de interesse. As imagens de vídeo transmitidas pela aeronave são sobrepostas por uma imagem de um painel de avião. O resultado dessa combinação é semelhante aos simuladores de vôos, tal como o Flight Simulator da Microsoft[MIC99]. Os instrumentos visualizados no computador são completamente funcionais com os valores mostrados obtidos dos sensores a bordo da aeronave. Essa configuração permite vôos além do alcance visual e controle da rota e altitude do vôo. Uma vez que a área escolhida para ser observada esteja sobre o foco da câmera de vídeo voltada para baixo, o piloto poderá disparar a câmera fotográfica ou acionar um gravador de vídeo.

Fase III: Classificada por Souza como tipo III, esta fase $\epsilon$ similar à fase II, utilizando aeromodelos equipados com software a bordo para a realização de operações autônomas. $O$ operador pode programar a rota de vôo da aeronave e as tarefas para cumprir a meta de uma missão, tais como fotografar ou filmar uma área pré-definida de forma completamente autônoma. A aeronave deverá retornar à base para um pouso assistido ou não, depois de realizar a missão programada. 
Fase IV: Essa fase inclui um sistema de processamento de imagens a bordo. A aeronave poderá identificar objetos, tais como linhas de transmissão, estradas, cursos de rios, etc. Esta fase deverá permitir uma variedade de tarefas de monitorização totalmente autônomas, como a inspeção de linhas de transmissão de energia com a finalidade de localizar possíveis falhas ou a contagem de animais em uma determinada área.

\subsection{Hardware do Sistema}

O diagrama apresentado na figura 3.1 mostra uma visão geral dos principais componentes necessários para a implementação do Projeto ARARA na fase II. O Transmissor $\mathrm{RC}$ envia as informações de controle para o aeromodelo ( $u$ plink), podendo esse controle ser feito através do módulo Controle do RC por Computador, dando origem a sistemas com vôo assistido por computador. As informações para o controle da instrumentação a bordo da aeronave também são enviadas pelo Transmissor RC, utilizando-se alguns dos seus canais.

Os comandos enviados para controlar a instrumentação de bordo são do tipo "selecione Câmera de Vídeo" ou "acione Câmera Fotográfica". O Computador de Bordo coleta as informações dos sensores da aeronave e as transfere para o Transmissor de Bordo que as envia para o Computador da Estação Base (downlink).

As informações dos sensores são transmitidas por um modem utilizando-se o canal de áudio do Transmissor de Bordo. As imagens apresentadas têm transmissão analógica. $O$ Receptor de Dados recebe as informações transmitidas pelo Transmissor de Bordo e as disponibiliza para o programa de visualização, a uma taxa de duas informações por segundo.

O protocolo simplex implementado para a comunicação entre a aeronave e o Computador da Estação Base foi especificado por Souza e descrito na seção 2.4.5. 


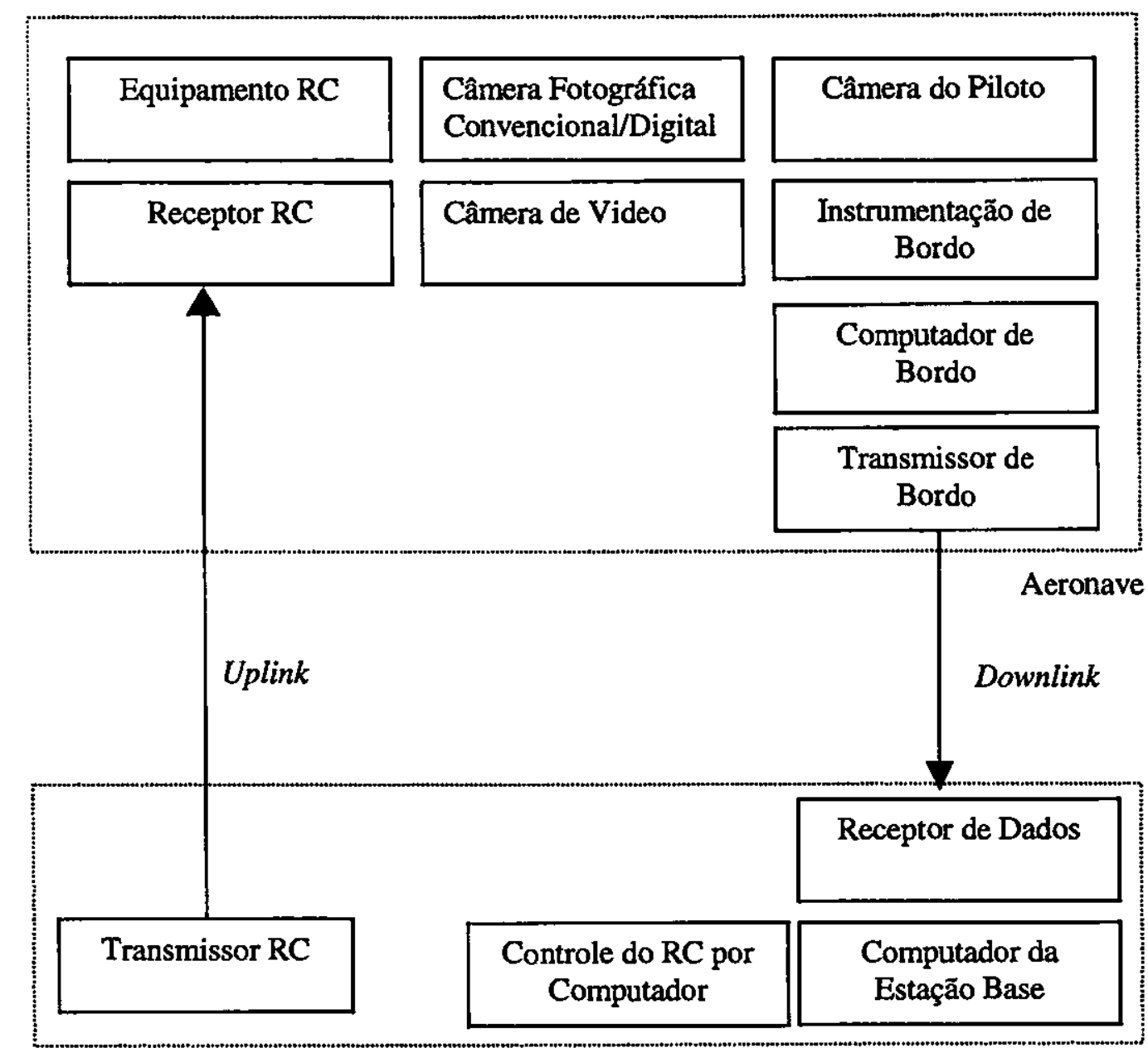

Estação Base

Figura 3.1 Diagrama de blocos do hardware do ARARA.

\subsubsection{Requisitos Funcionais de Hardware}

Os seguintes requisitos funcionais devem ser atendidos pelo hardware do sistema:

- O transmissor RC deve ter alcance de pelo menos $15 \mathrm{~km}$ e deve controlar pelo menos 7 canais;

- O motor deve ter potência suficiente para que a aeronave possa decolar quando arremessada manualmente;

- As asas da aeronave devem ser projetadas para obter alto coeficiente de sustentação; 
- A aeronave deve decolar de uma catapulta ou arremessada com as mãos. Deve ser também possível a instalação de trem de pouso para decolagem convencional;

- A aeronave deve possuir compartimentos para a instalação dos equipamentos eletrônicos. A carga útil deve ser de pelo menos $3 \mathrm{Kg}$;

- O Computador da Estação Base deve ser capaz de executar o software do sistema e dispor de uma placa para recepção de sinais de TV e um modem;

- O computador a bordo da aeronave deve ter baixo consumo de energia e potência computacional suficiente para executar o software que realiza a aquisição e a transmissão dos dados;

- O receptor GPS a bordo da aeronave deve ter precisão melhor que 25 metros;

- Devem estar disponíveis na aeronave os seguintes sensores: temperatura ambiente, temperatura do motor, temperatura dos gases do escapamento do motor, altímetro, velocidade do vento, sensor de tensão das baterias, tacômetro, horizonte artificial, bússola e indicador de combustível;

- Devem estar disponíveis duas câmeras de vídeo e uma câmera fotográfica digital; Opcionalmente, podem estar disponíveis um gravador de vídeo e uma câmera fotográfica convencional. Deve ser possível o acionamento remoto das câmeras fotográficas através de comandos de rádio;

- Os dados dos sensores devem ser transmitidos através do canal de áudio do transmissor;

- Deve existir uma chave que permita a seleção, através de um comando de rádio, da câmera de vídeo conectada ao transmissor.

\subsubsection{Requisitos não Funcionais de Hardware}

Abaixo são apresentados os requisitos não funcionais do hardware do sistema:

- A construção da aeronave deve ser realizada utilizando técnicas e materiais utilizados na construção de aeromodelos para minimizar o seu custo e facilitar o seu desenvolvimento; 
- Para facilitar o transporte da aeronave, a mesma deve ser desmontável em módulos de fácil acoplamento;

- O motor deve ser do tipo a explosão, movido à gasolina ou álcool etílico, e deve utilizar um sistema de ignição eletrônica para melhorar o seu rendimento e confiabilidade;

- O peso total da aeronave não deve exceder a $10 \mathrm{~kg}$, permitindo a utilização de motores de até $25 \mathrm{cc}$.

\subsection{Software do Sistema}

\subsubsection{Requisitos Funcionais de Software}

O software da fase II do Projeto ARARA foi denominado STT (Sistema de Telemetria e Telecomando). As funções do sistema podem ser agrupadas em dois módulos: MA (Módulo Aéreo), cobrindo o software embarcado na aeronave e MB (Módulo Base), cobrindo o software da Estação Base. Abaixo são apresentados os requisitos funcionais dos módulos Aéreo e Base:

- Ao ligar o sistema, um procedimento de autoteste para a verificação do funcionamento dos sensores deve ser executado. Caso algum deles apresente uma falha, um aviso sonoro deve ser emitido. As falhas também devem ser apresentadas em um mostrador de cristal líquido;

- Durante o vôo da aeronave, todos os sensores devem ser continuamente monitorados para a deteç̧ão de falhas. As falhas detectadas devem ser informadas à Estação Base e reportadas para o operador através do painel de instrumentação;

- Os dados coletados pelos sensores devem ser periodicamente lidos pelo computador principal da aeronave em intervalos regulares de 0,5 segundos;

- Os dados devem ser continuamente recebidos pelo Módulo Base, através do receptor de TV e do modem. Todos os pacotes devem ser enviados com check-sum. Os pacotes que apresentam erros de verificação de chek-sum devem ser descartados; 
- O sistema deve apresentar ao operador uma interface gráfica intuitiva semelhante ao painel de um avião convencional. No painel, são mostrados os instrumentos necessários para a realização de vôo por instrumentos. Os instrumentos devem ter a seguinte apresentação:

o Rotação do Motor (tacômetro): Informa o número de rotações por minuto do motor. A escala do mostrador deve variar de 0 a 20.000 RPM. O mostrador deve ser do tipo analógico, para facilidade de leitura rápida;

- Indicador de Temperatura Externa: A escala deste mostrador deve estar graduada em graus Celsius, podendo variar de $-50 \mathrm{a}+50^{\circ} \mathrm{C}$. O mostrador deve ser do tipo digital, para melhor precisão de leitura;

- Indicador de Temperatura dos Gases do Escapamento: A escala deste mostrador deve estar graduada em graus Celsius e variar entre $0^{\circ}$ e $500^{\circ} \mathrm{C}$. O mostrador deve ser do tipo analógico;

- Indicador de Temperatura do Motor: A escala deste mostrador deve estar graduada em graus Celsius e variar entre $0^{\circ}$ e $500^{\circ} \mathrm{C}$. O mostrador deve ser do tipo analógico;

- Indicador de Combustível: A escala desse mostrador deve estar graduada em porcentagem de combustível restante, entre 0 e $100 \%$. A escala deve ser apresentada na forma de um gráfico de barras colorido, indicando em vermelho a condição de nível baixo de combustível;

- Indicador de Bateria do Receptor: A escala desse mostrador deve apresentar o nível de tensão da bateria do receptor de rádio-controle. A escala deve ser apresentada na forma de um gráfico de barras colorido, indicando em vermelho a condição de nível baixo de tensão;

- Indicador de Bateria do Sistema: A escala desse mostrador deve apresentar o nível de tensão da bateria principal do sistema. A escala deve ser apresentada na forma de um gráfico de barras colorido, indicando em vermelho a condição de nível baixo de tensão;

- Altímetro: Indica a altitude, em pés, em relaçăo ao nível do mar. A escala desse mostrador varia entre -5000 e $+5000 \mathrm{~m}$. O mostrador deve ser do tipo analógico;

- Horizonte Artificial ou Indicador de Atitude: Indica a posição do avião em relação ao horizonte (arfagem e rolamento). Os eixos de arfagem e rolamento 
devem ser representados graficamente por um avião em miniatura visto em relação à linha do horizonte. A figura 2.4 (à direita) fornece um exemplo;

- Bússola: Indica ao piloto onde está o norte magnético. O mostrador deve representar uma bússola analógica convencional;

- Bússola Giroscópica: Semelhante à bússola, porém, não é afetada pelo balanço da aeronave. $\mathrm{O}$ mostrador é representado por uma bússola analógica. A figura 2.4 (à esquerda) fornece um exemplo.

- Indicador de velocidade do ar: A escala desse mostrador deve variar entre $0 \mathrm{e}$ $300 \mathrm{~km} / \mathrm{h}$. O mostrador deve ser do tipo analógico;

- GPS (Global Positioning System): As informações disponíveis no painel do GPS são:

- Latitude: em graus, minutos e segundos;

- Longitude: em graus, minutos e segundos;

- Velocidade: em $\mathrm{km} / \mathrm{h}$;

- Altitude: em metros;

- Distância da Estação Base: a escala também é mostrada em metros;

- A apresentação gráfica de cada instrumento deve seguir o estilo presente no painel de uma aeronave convencional;

- Os dados recebidos dos sensores devem ser formatados de acordo com cada instrumento mostrado no painel $\mathrm{e}$ as atualizações devem ser realizadas em intervalos constantes de 1 segundo;

- O operador deve poder selecionar a fonte da imagem, ou seja, imagens recebidas através do receptor de TV ou através de uma entrada de vídeo composto;

- O software deve fornecer ao operador uma interface para a visualização de fotos armazenadas no disco do computador da Estação Base. A interface deve permitir a visualização de fotos nos formatos JPEG ou BMP;

- O sistema deve verificar periodicamente a distância entre a aeronave e a Estação Base. Esta monitorização deve ser realizada para que a aeronave permaneça dentro do raio de alcance do transmissor. Um aviso sonoro e um indicador luminoso 
devem ser acionados quando a aeronave está preste a sair do alcance do transmissor;

- O nível de combustível deve ser constantemente monitorado pelo sistema. Um alarme visual na cor laranja deve ser acionado quando o indicador de combustível entra na faixa vermelha, informando ao operador que o sistema está em nível crítico;

- Sempre que o operador abre o canal do modem, o sistema deve iniciar o processo de gravação dos valores da telemetria recebidos pela Estação Base. A cada vôo deve ser gerado um $\log$ desses valores. $O$ log deve ser continuamente gravado até o operador fechar o canal do modem. Com o canal do modem fechado, o operador deve poder editar qualquer arquivo de log anteriormente gravado;

- A interface usada para mostrar o arquivo de log deve ser uma tabela onde é permitida a troca das colunas de lugar. A interface do arquivo de log só pode ser chamada quando o sistema não estiver operante;

- Um relatório estatístico deve estar disponível para o operador após a abertura do arquivo de log. A análise estatística deve conter o valor mínimo, o valor máximo e a média dos valores de cada sensor durante o vôo da aeronave. As informações apresentadas neste relatório devem ser as seguintes:

- Velocidade;

o Distância de afastamento da Estação Base;

- Altitude;

- Temperatura do motor;

- Temperatura externa;

- Velocidade do vento;

- Temperatura dos gases de escape;

- Como a interface da ferramenta STT é inspirada nas interfaces dos simuladores de vôo, todos os seus recursos devem ser implementados seguindo esse modelo. Deste modo, o projeto da interface deve ser semelhante ao do simulador de vôo mais conhecido do mercado, o Flight Simulador da Microsoft [MIC99]; 
- A interface do painel deve ocupar 1/5 da tela. Durante o vôo, o operador deve poder escolher um outro painel onde são mostrados somente os instrumentos indispensáveis para o acompanhamento do vôo da aeronave, ocupando apenas 1/8 da tela disponível. Os instrumentos disponíveis nesta configuração devem ser:

- Nível de Combustível;

○ GPS;

- Tensão das Baterias do Sistema;

- Tensão das Baterias do Receptor.

\subsubsection{Requisitos Não Funcionais de Software}

Os requisitos não funcionais do software são:

- Durante uma sessão de vôo não deve ser permitido executar nenhum outro aplicativo em background, tais como editores de texto, gráficos, planilhas, screensaver, etc. Alguns aplicativos do Windows podem bloquear o acesso ao driver de captura da placa de vídeo;

- Durante uma sessão de vôo deve ser reservado no mínimo 1 Mbyte de espaço em disco por minuto de sessão para o armazenamento do arquivo de $\log$;

- Para utilização do ARARA na fase II, é necessário que o operador tenha conhecimento de pilotagem de aeromodelo;

- O sistema não deve utilizar nenhum recurso de banco de dados para armazenar os registros de log. $\mathrm{O}$ arquivo de $\log$ deverá ser gerado a partir das funções básicas da linguagem de programação utilizada;

- O sistema operacional que equipa o computador de bordo da aeronave deve ser o Linux. Devido à limitação de memória e hardware, a versão utilizada deve ser configurada para executar somente os serviços básicos. O Mulinux [MUL99] é uma versão linux com kernel reduzido, adequada para a aplicação;

- O sistema executado na Estação Base deve ser o Windows 95 ou superior. O Windows deve possuir um driver de captura de vídeo, tal como o Tvtap VidCap. Esses drivers geralmente são distribuídos junto com as placas de captura de vídeo. 


\subsection{Considerações Finais}

Neste capítulo foram apresentados os requisitos de hardware e software para a implementação da fase II do Projeto ARARA. Uma definição do Projeto ARARA foi apresentada e foi definida a forma como o projeto está estruturado.

Para melhor compreensão do sistema proposto, foi apresentado um diagrama de blocos que possibilita visualizar o hardware do sistema. A função de cada bloco foi especificada.

Também foram explanados neste capítulo alguns detalhes da interface do sistema com o operador e a forma como os instrumentos devem ser apresentados.

A especificação e o projeto do sistema proposto são apresentados no próximo capítulo, na forma de análise de eventos e DFDs (Diagrama de Fluxo de Dados). 


\section{Capítulo 4}

\section{Especificação e Projeto do Sistema}

\subsection{Considerações Iniciais}

A especificação e o projeto de hardware e de software da fase II do Projeto ARARA são apresentados neste capítulo. O STT (Sistema de Telemetria e Telecomando) foi divido em dois módulos: MA (Módulo Aéreo) e MB (Módulo Base). São apresentados diagramas de contexto para o sistema como um todo e para cada módulo individualmente.

Na seção 4.2, são apresentados a especificação e o projeto preliminar do hardware do sistema. Uma extensão para a análise de sistemas de tempo real, que será utilizada na análise do software, é apresentada na seção 4.3. Na seção 4.4, é apresentada a lista de eventos que ocorrem no sistema e na seção 4.5, é mostrado o diagrama de contexto do STT. Nas seções 4.6 e 4.7, são apresentados os diagramas de contexto do STT - MA e MB, respectivamente. Nas seções 4.8 e 4.9, são apresentados os diagramas de fluxo de dados de nível 1 do STT - MA e MB. Na seção 4.10, é feita a descrição de cada processo apresentado no DFD de nível 1 dos dois módulos. Na seção 4.11, são feitas as considerações finais deste capítulo.

\subsection{Especificação e Projeto Preliminar de Hardware}

A fase II do Projeto ARARA, mais complexa que a fase $\mathrm{I}$, requer componentes mais sofisticados para o seu funcionamento. A figura 4.1 apresenta um diagrama de blocos que detalha a ligação entre os componentes de hardware montados dentro da aeronave e no computador da Estação Base. 


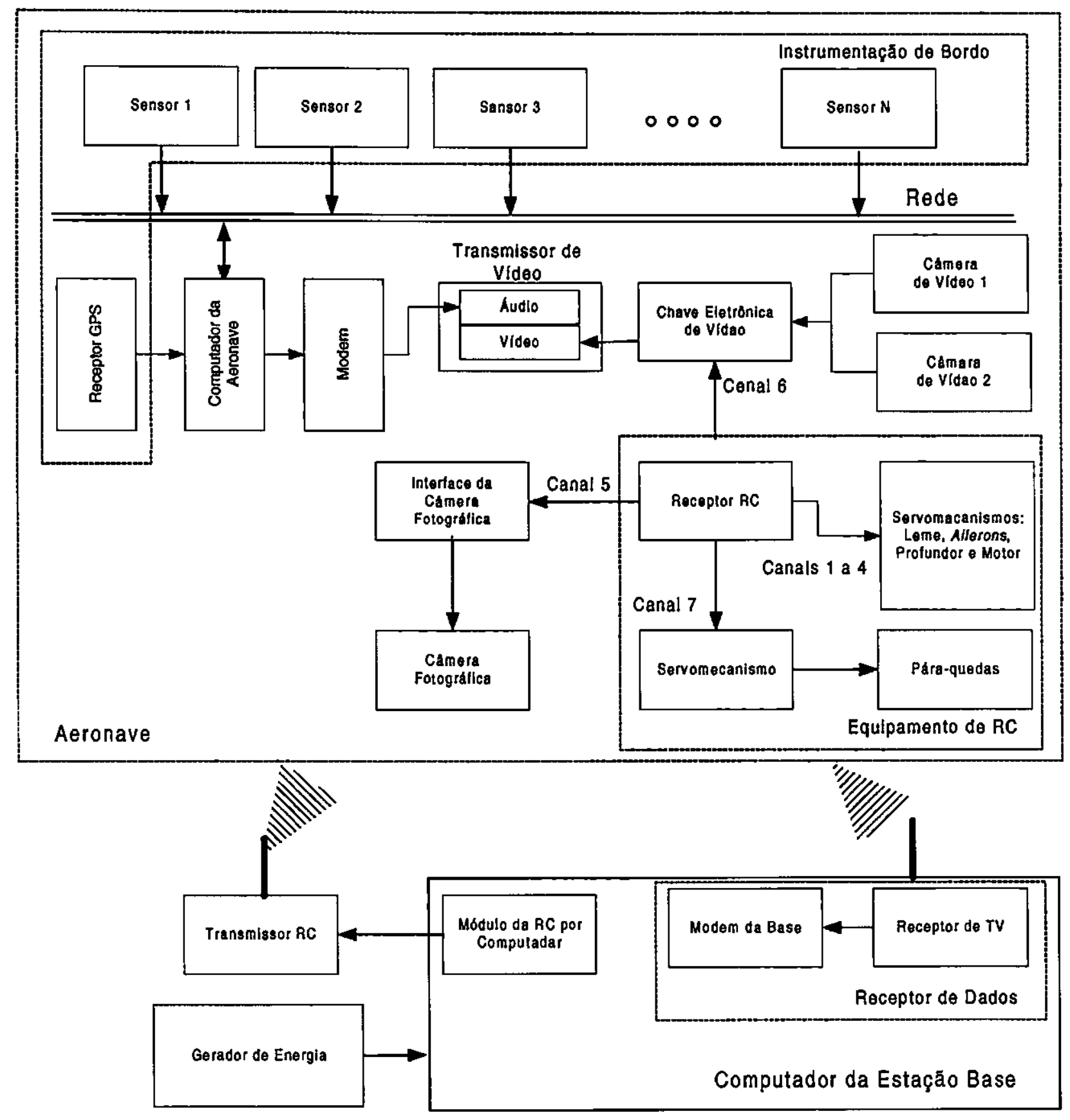

Figura 4.1 Diagrama de blocos detalhado da Fase II.

- Computador da Estação Base: Utilizado para a visualização dos valores de telemetria dos instrumentos instalados a bordo da aeronave, das imagens de vídeo transmitidas e para o controle da estação em solo;

- Receptor de TV: Uma placa de TV, instalada no Computador da Estação Base, faz o papel do receptor de TV. A mesma é utilizada para receber as imagens e o áudio 
transmitidos pela aeronave. A placa pode operar nas freqüências de UHF e possui entrada e saída de vídeo NTSC (National Television Standards Committee). A saída de ádio da placa está conectada na entrada line do modem;

- Modem da Base: Utilizado para demodular o sinal de áudio recebido pelo Receptor de TV, operando a 1200 ou 2400 bps;

- Transmissor RC: Transmite sinais de rádio-controle para o receptor a bordo da aeronave. Dispõe de oito canais e memória para armazenar os ajustes finos de posição do leme, ailerons, flap, etc. O Transmissor RC é do tipo PCM para minimizar problemas de interferência e ruídos;

- Receptor RC: Utilizado para receber os sinais de rádio-controle transmitidos pelo transmissor da Estação Base. O receptor permite controlar 8 canais. Quatro canais de controle são destinados para o aeromodelo (potência do motor, ailerons, leme e profundor). Um quinto canal é utilizado para o controle da Interface da Câmera Fotográfica. Um sexto canal é utilizado para controlar a Chave Eletrônica de Vídeo e um sétimo canal para o acionamento do pára-quedas;

- Gerador de Energia: Utilizado para alimentar o Computador da Estação Base em lugares onde não existe suprimento de energia elétrica. $O$ gerador possui saída de tensão biVolt $110 / 220$ e uma saída de 12 VCC. O peso do gerador não excede $10 \mathrm{~kg}$ e é capaz de alimentar todo o sistema, permitindo inclusive a recarga das baterias da aeronave;

- Receptor GPS: O receptor está conectado na porta serial do Computador da Aeronave. O receptor GPS possui entrada para GPS diferencial e precisão melhor que 25 metros;

- Computador da Aeronave: Foi selecionado um PC-104 devido à restrição de peso e consumo de energia. O modelo selecionado possui 4 Mbytes de memória, 2 Mbytes de memória de estado sólido, 4 portas seriais e 1 porta paralela. A porta paralela é utilizada para implementar a rede a bordo da aeronave;

- Transmissor de Vídeo: Utilizado para a transmissão de imagens e dados. Diversas opções podem ser usadas para essa função, incluindo transmissores analógicos de som e imagem e modems de RF (ou uma combinação desses dispositivos). $O$ transmissor selecionado opera na freqüuência de UHF com alcance superior a $3 \mathrm{~km}$ e transmissão analógica de vídeo no padrão NTSC. No canal de áudio do transmissor está conectado o 
modem e na entrada de vídeo está conectada a Chave Eletrônica de Vídeo;

- Chave Eletrônica de Vídeo: A chave eletrônica é composta por uma interface e um multiplexador de vídeo. A interface lê o sinal do receptor $\mathrm{R} / \mathrm{C}$ e realiza a comutação do sinal de vídeo enviado pelas Câmeras de Vídeo l e 2;

- Câmera de Vídeo 1: Esta câmera tem o papel de auxiliar o piloto na navegação. A câmera selecionada é do tipo monocromática e a mesma está ligada à Chave Eletrônica de Vídeo;

- Câmera de Vídeo 2: Esta câmera está instalada na posição vertical e ajuda o piloto na seleção da área de interesse para monitorização. A Câmera de Vídeo 2 é colorida e está ligada à Chave Eletrônica de Vídeo;

- Rede: Dentro da aeronave utiliza-se uma rede $\mathrm{I}^{2} \mathrm{C}$ (Inter-IC). A rede $\mathrm{I}^{2} \mathrm{C}$ permite que múltiplos dispositivos atuem como master. A rede $\mathrm{I}^{2} \mathrm{C}$ é fácil de ser implementada e existe uma grande quantidade de sensores que são compatíveis com este padrão. No Computador da Aeronave, a rede é realizada utilizando a porta paralela. Todos os sensores, com exceção do receptor GPS, estão ligados através da rede $\mathrm{I}^{2} \mathrm{C}$;

- Interface da Câmera Fotográfica: Esta interface permite controlar a câmera fotográfica. A interface está conectada ao receptor $\mathrm{RC}$ e pode ser configurada para trabalhar em diversos modos de operação, conforme descrito no trabalho de Souza [SOU99];

- Câmera Fotográfica: Devido à restrição de peso, a câmera selecionada possui baixo peso e baixo consumo de energia. A câmera está conectada ao módulo de Interface da Câmera Fotográfica. $\mathrm{O}$ foco da câmera está direcionado para baixo;

- Sensor 1..N: Vários sensores equipam o ARARA na fase II. Todos os sensores citados abaixo estão conectados à rede $I^{2} \mathrm{C}$. São eles:

- Sensor de Temperatura Ambiente: Mede a temperatura externa da aeronave;

- Sensor de Temperatura do Motor: Indica a temperatura do motor no cabeçote, perto da vela de ignição;

- Sensor de Temperatura dos Gases do Escapamento: Mede a temperatura dos gases do escapamento do motor. Essa medição é importante para que se possa 
ajustar a relação da mistura ar-combustível e proporcionar o melhor regime de funcionamento do motor, evitando-se seu sobre-aquecimento ou parada [PAL85];

- Altímetro Convencional: $O$ altímetro é o instrumento que indica a altitude do avião. $O$ princípio de funcionamento mais comum do altímetro é pela medida da pressão atmosférica [PAL85] [SOU99]. Para determinar a altura da aeronave, o sensor deve ser calibrado utilizando-se a pressão local relativa ao nível do mar;

- Velocidade do Vento: Fornece a velocidade do ar em relação à aeronave. O sensor é implementado utilizando-se um sensor de pressão diferencial;

- Sensor de Tensão das Baterias: Mede a tensão das baterias do sistema. O sensor possui entrada para os diversos conjuntos de baterias presentes na aeronave;

- Sensor de RPM: Mede o número de rotações por minuto do motor;

- Horizonte Artificial: Registra a atitude da aeronave no espaço (arfagem e rolagem). Para a implementação deste sensor são utilizados inclinômetros e giroscópios;

- Bússola: Indica o norte magnético;

- Bússola Giroscópica: Semelhante à bússola, porém, não é afetada pelo balanço da aeronave;

- Indicador de Combustível: Indica o nível de combustível, conseqüentemente o tempo restante de vôo [SOU99].

\subsection{Notação estendida de Ward e Mellor}

Muitas aplicações são dependentes do tempo e processam informações orientadas a controle. A análise estruturada falha para essa classe de problemas por não trazer uma notação específica para representar questões relacionadas a controle ou eventos que ocorrem simultaneamente, como é o caso dos sistemas de tempo real [PRE95].

Para acomodar a análise de sistemas de tempo real, uma série de extensões foi adicionada ao modelo clássico da análise estruturada. Estas extensões foram desenvolvidas por Ward e Mellor [WAR85] e estão ilustradas na figura 4.2. Elas permitem que o analista possa 
representar o fluxo de controle e o processamento do controle tão bem quanto o fluxo de dados e o processamento de dados.

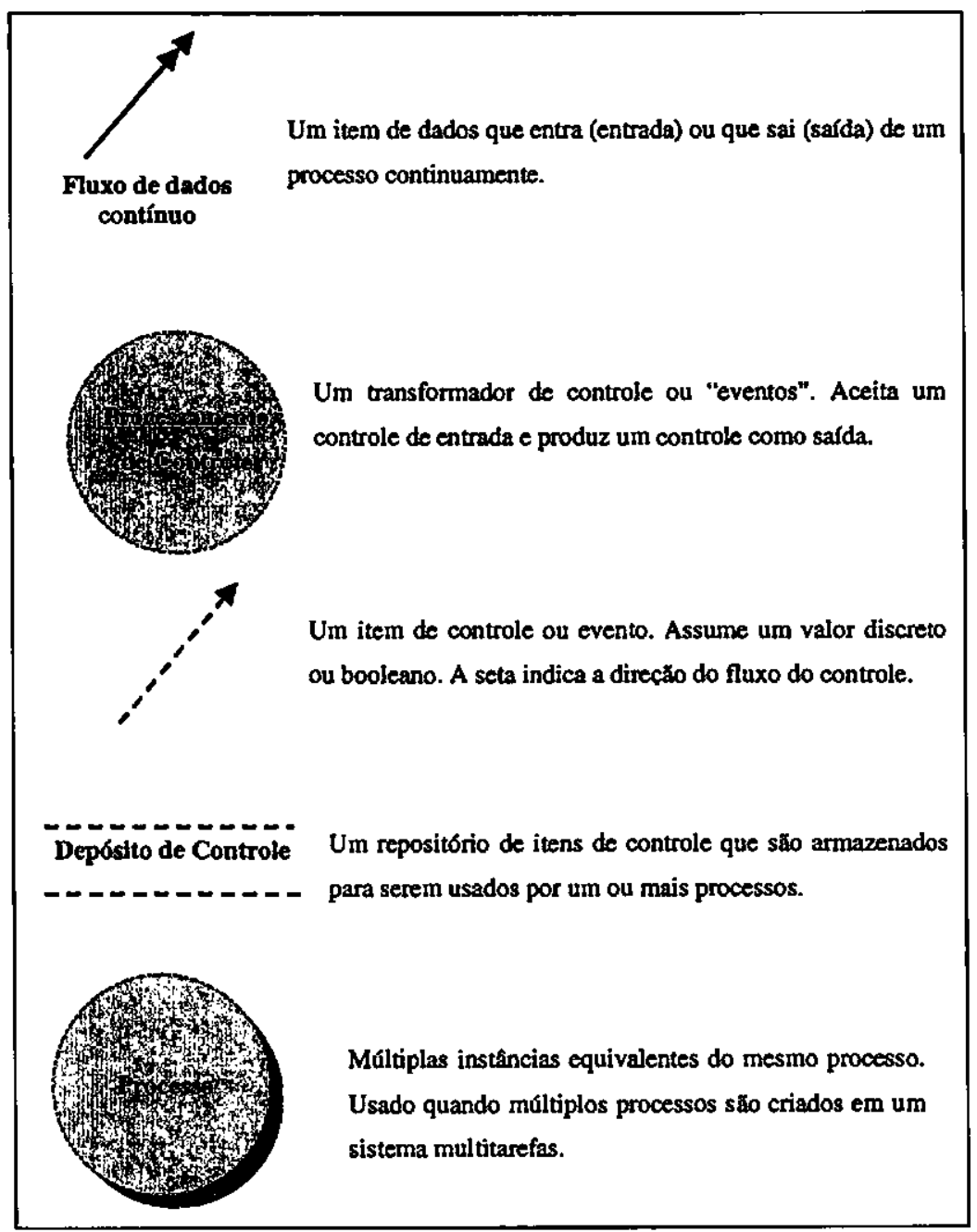

Figura 4.2 Notação de análise estruturada estendida para sistemas de tempo real.

\subsection{Lista de Eventos do Sistema}

1) STT - MB monitora nível de combustível;

2) Operador lê arquivo de $\log$ no STT - MB;

3) STT - MB grava arquivo de $\log$;

4) Operador solicita estatística do arquivo de $\log$ no STT - MB;

5) STT - MB lê os dados na porta serial;

6) STT $-\mathrm{MB}$ atualiza os instrumentos do painel;

7) STT - MB verifica a distância entre a aeronave e a Estação Base; 
8) STT -MA verifica as condições operacionais dos sensores;

9) STT - MA e MB reporta falha dos sensores;

10) STT - MA transmite dados dos sensores para a porta serial;

11) STT - MA coleta dados dos sensores;

12) Operador vê as fotos da câmera fotografica no STT - MB;

13) STT - MB atualiza as imagens recebidas pelo transmissor;

14) Operador seleciona a fonte da imagem no STT - MB;

15) STT - MB lê o arquivo de configuração do sistema;

16) STT - MB gera mostradores para o painel de controle;

17) Operador abre canal do modem do STT - MB;

18) Operador fecha canal do modem do STT - MB;

19) Operador escolhe painel alternativo no STT - MB. 


\subsection{Diagrama de Contexto do STT}

Com o STT, o operador pode visualizar os dados dos sensores instalados a bordo da aeronave e as imagens transmitidas pelas câmeras de vídeo. A interface do STT é semelhante a um simulador de vôo. O STT registra a telemetria dos sensores de bordo em um arquivo de $\log$ durante uma sessão de vôo. O log gravado pode ser visualizado. Também é possível emitir relatórios estatísticos dos dados coletados pelos sensores.

A figura 4.3 mostra o Diagrama de Contexto do STT. No diagrama estão representadas as entradas, as saídas e os eventos que o sistema responde.

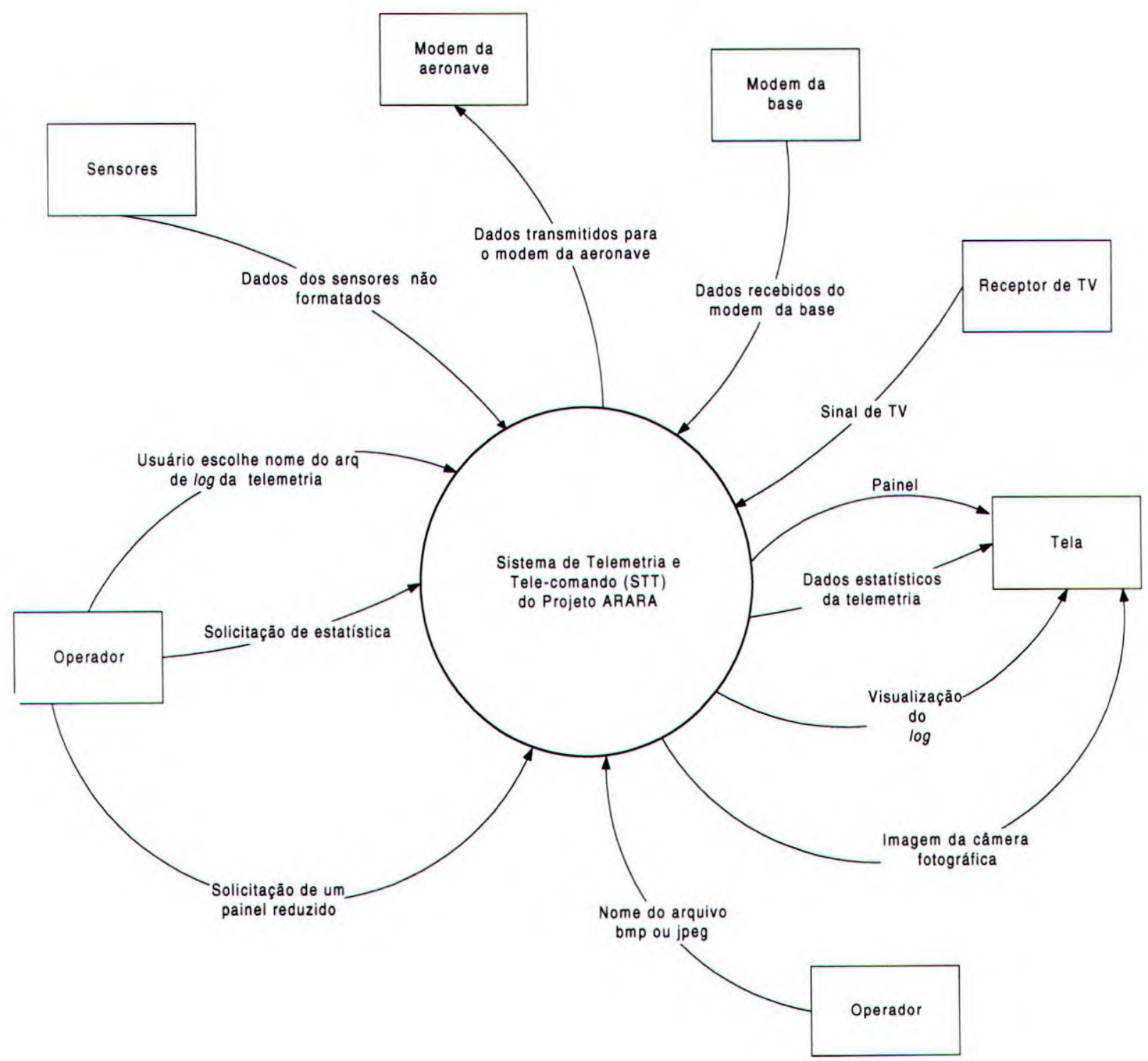

Figura 4.3 Diagrama de Contexto do STT. 


\subsection{Diagrama de Contexto do STT - MA}

: A figura 4.4 mostra o diagrama de contexto do STT - MA. Este subsistema é respònsável por coletar e transmitir os dados dos sensores para o computador da Estação Base. Também faz parte das suas funções reconhecer as falhas dos sensores quando ocorrerem.

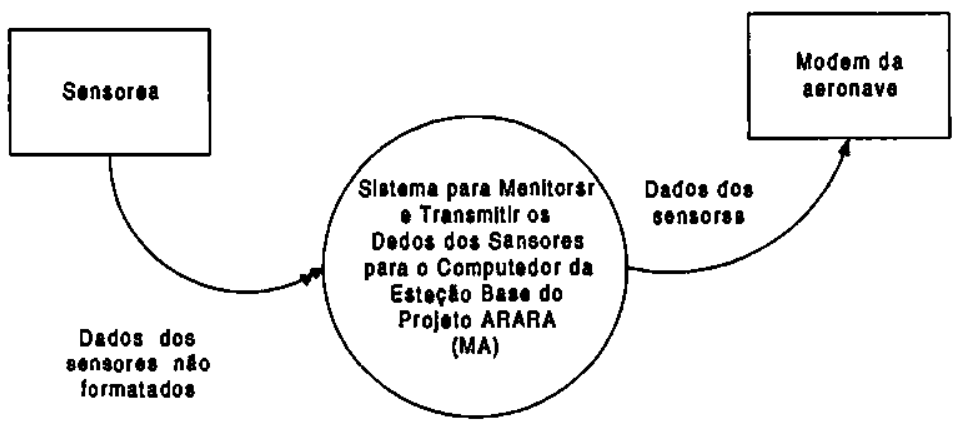

Figura 4.4 Diagrama de Contexto do STT - MA.

\subsection{Diagrama de Contexto do STT - MB}

A figura 4.5 mostra o diagrama de contexto do STT - MB. Este subsistema é responsável pela visualização dos dados da telemetria enviados pela aeronave. Os dados dos sensores são visualizados em instrumentos semelhantes ao de uma aeronave convencional. $O$ registro de $\log$ e a estatística dos valores dos sensores são feitos por este subsistema.

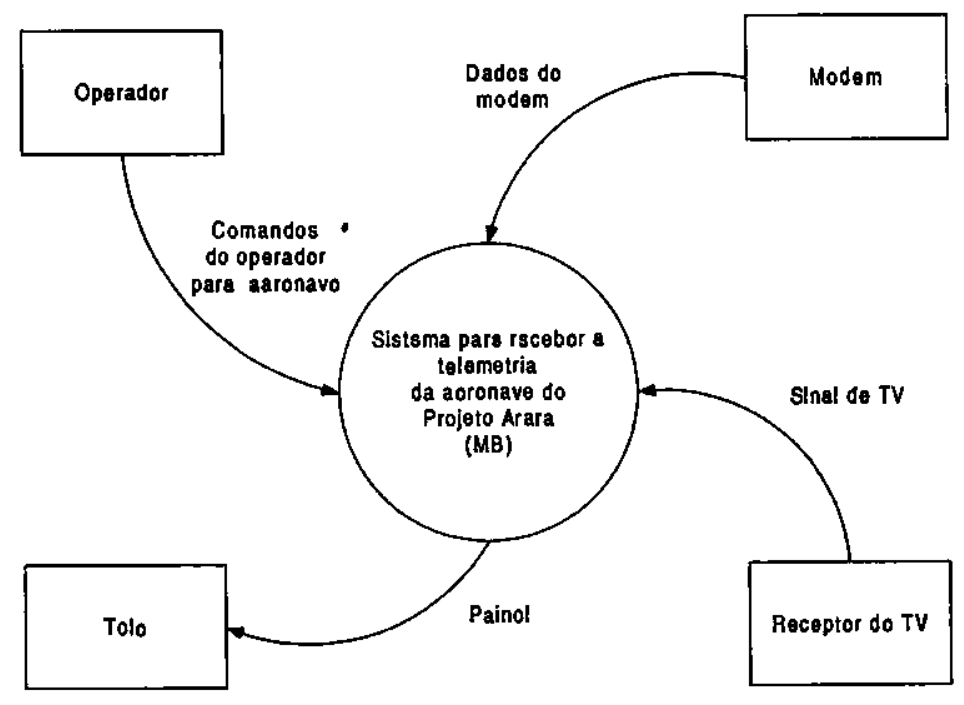

Figura 4.5 Diagrama de Contexto do STT - MB. 


\subsection{Diagrama de Fluxo de Dados - Nível1 (STT - MA)}

A figura 4.6 mostra o DFD de nível 1 do diagrama de contexto do STT - MA apresentado na figura 4.4. O DFD foi construído a partir da lista de eventos.

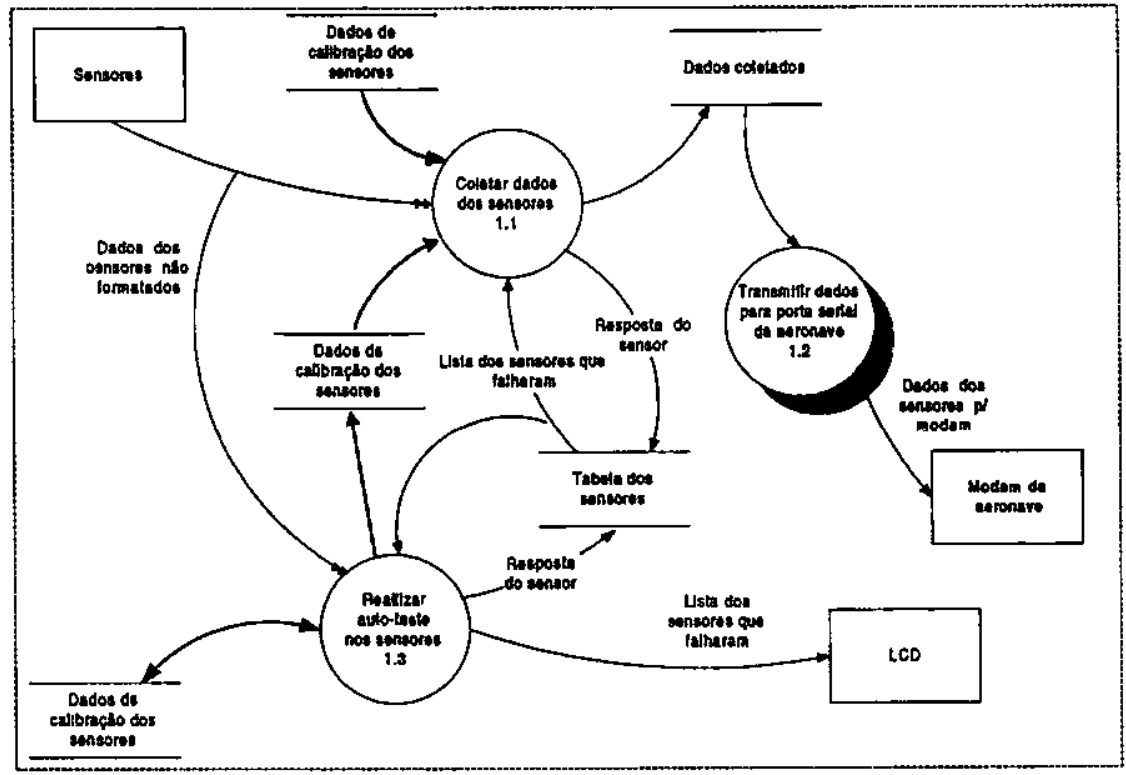

Figura 4.6 DFD Nível 1 - Módulo Aéreo. 


\subsection{Diagrama de Fluxo de Dados - Nível 1 (STT - MB)}

A figura 4.7 mostra o DFD de nível 1 do STT - MB. Este DFD foi criado a partir da lista de eventos. Nas seções subsequientes são apresentados os detalhes de cada processo.

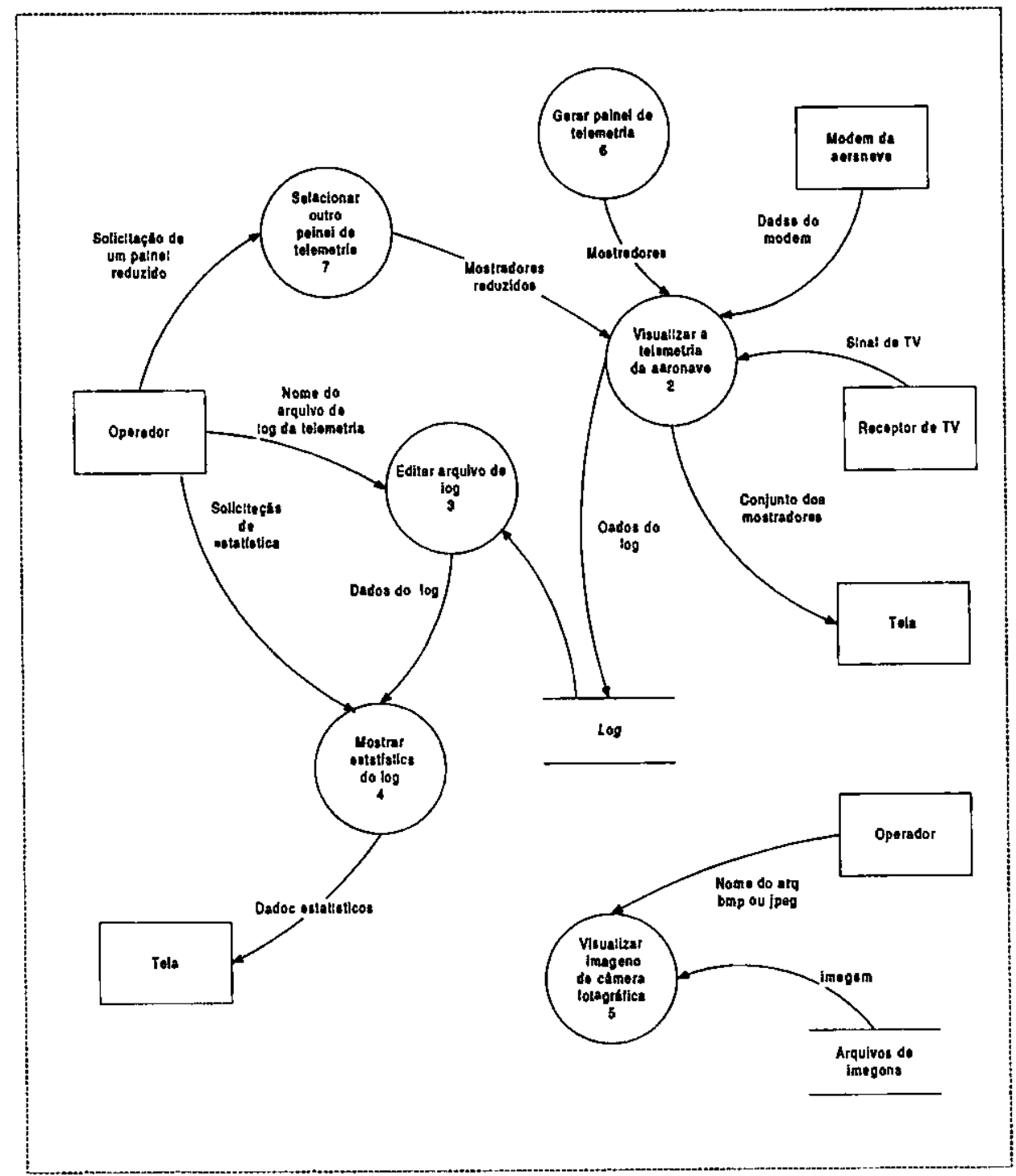

Figura 4.7 DFD Nível 1 - Módulo Base. 


\subsection{Descrição dos DFDs}

Nas próximas subseções, é apresentada a descrição de cada processo mostrado no DFD Nível 1 - MB e MA. Junto de cada descrição, são apresentados os DFDs de segundo nível do sistema. Os fluxos que são b́bvios não são nomeados para melhorar a visualização dos diagramas. Este método é citado por Shiller [SHI92].

\subsubsection{DFD 2 - Visualizar a Telemetria da Aeronave}

Este módulo realiza a principal atividade do sistema, monitorar a telemetria. Nele o operador acompanha as imagens e os dados dos sensores transmitidos pela aeronave.

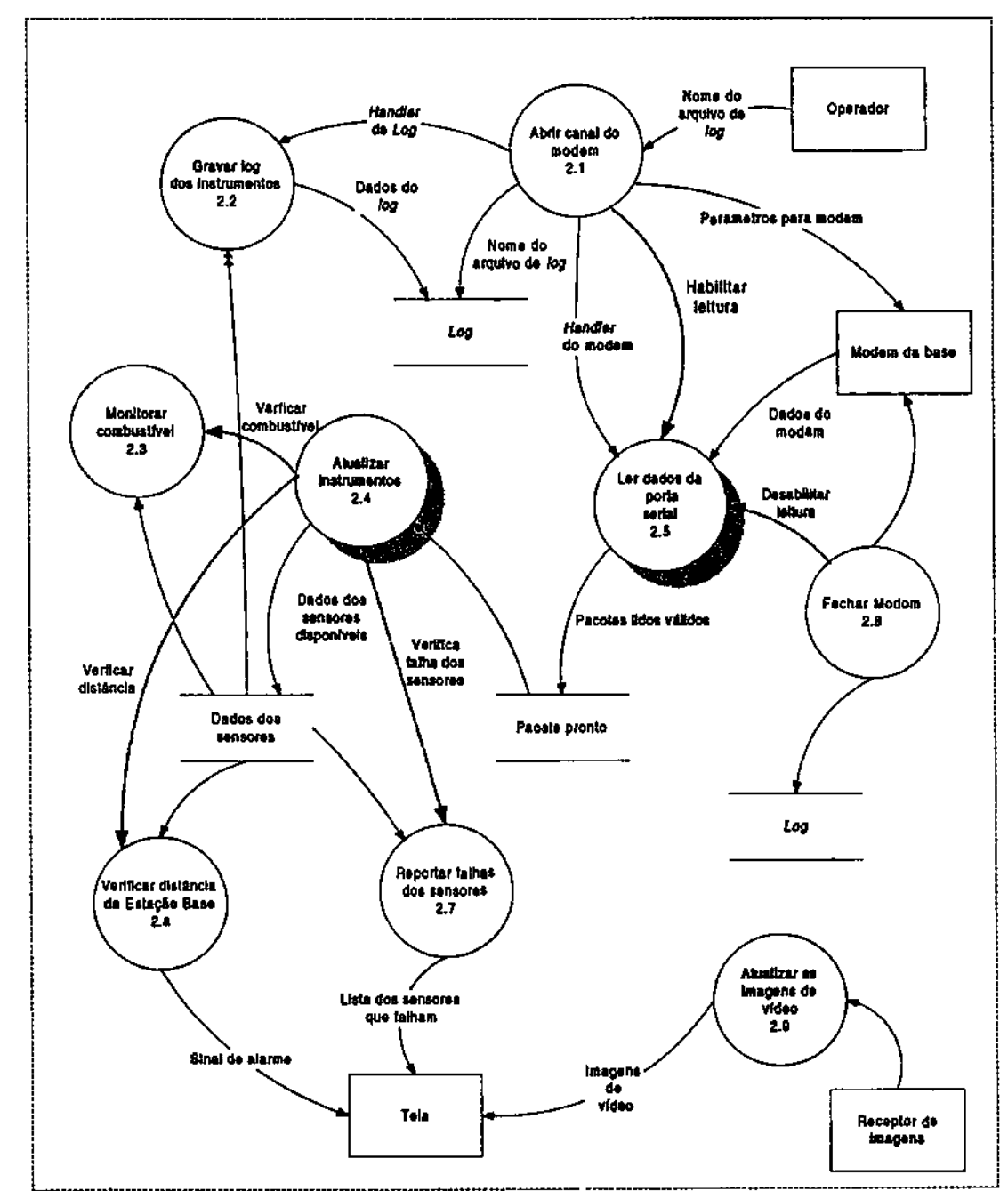

Figura 4.8 DFD 2 - Visualizar a telemetria da aeronave.

Quando o operador abre o canal de modem (figura 4.8 - processo 2.1), um handler é 
passado para a função Ler Dados da Porta Serial (figura 4.8 - processo 2.5), representada no diagrama por um processo concorrente. Esta função somente é ativada quando recebe um fluxo de controle. Este fluxo pode ser visualizado na figura 4.8 por uma linha tracejada. A função Atualizar Instrumentos também é ativada somente quando o modem é aberto. Quando a função Atualizar Instrumentos (figura 4.8 - processo 2.4) é executada, as funções Monitorar Combustível (figura 4.8 - processo 2.3), Reportar Falha dos Sensores (figura 4.8 - processo 2.7) e Verificar Distância da Estação Base (figura 4.8 - processo 2.6) são invocadas por ela.

\subsubsection{DFD 3 - Editar Arquivo de Log}

Este módulo permite ao operador editar o arquivo de telemetria, também referenciado por arquivo de log.

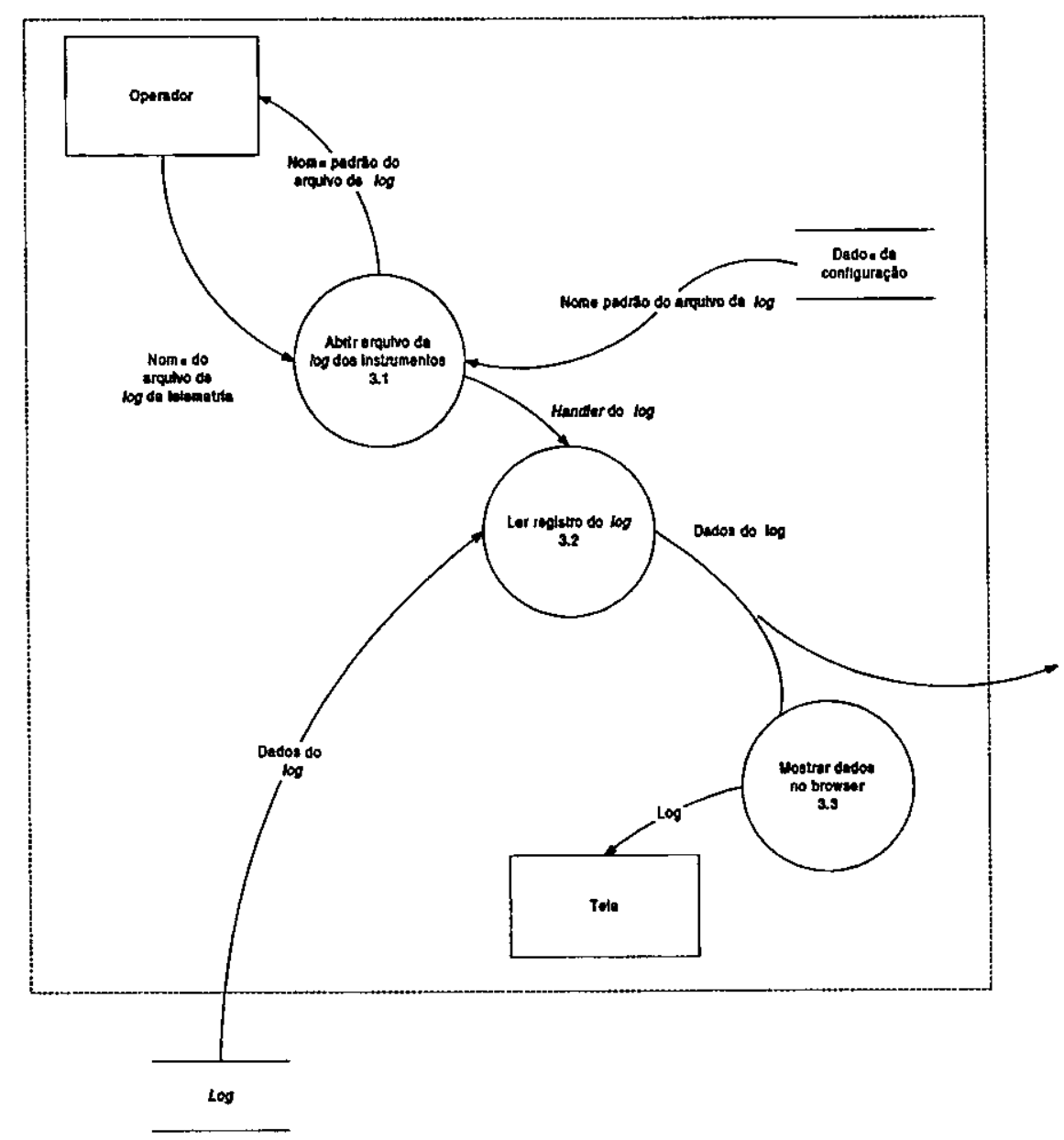

Figura 4.9 DFD 3 - Editar arquivo de log.

A função Abrir Arquivo de $\log$ dos Instrumentos (figura 4.9 - processo 3.1), abre o depósito Dados da Configuração que contém os parâmetros do sistema. O parâmetro contendo o 
nome do arquivo de log é enviado para o operador. Em seguida, a função Ler Registro de Log (figura 4.9 - processo 3.2), abre o depósito que contém o arquivo de log solicitado. Durante o processo de leitura do arquivo, os dados são enviados para o módulo de estatística (ver seção 4.9), onde é feita a análise dos mesmos.

O módulo Editar Arquivo de $\log$ somente pode ser executado quando o canal do modem está fechado, ou seja, a aeronave está não operacional. A estrutura do arquivo de log está representada no dicionário de dados (DD) presente no Apêndice $\mathrm{A}$.

\subsubsection{DFD 4 - Mostrar Estatística do Log}

Este módulo realiza cálculos estatísticos sobre os registros de log lidos pelo módulo Editar Arquivo de Log (ver seção 4.9).

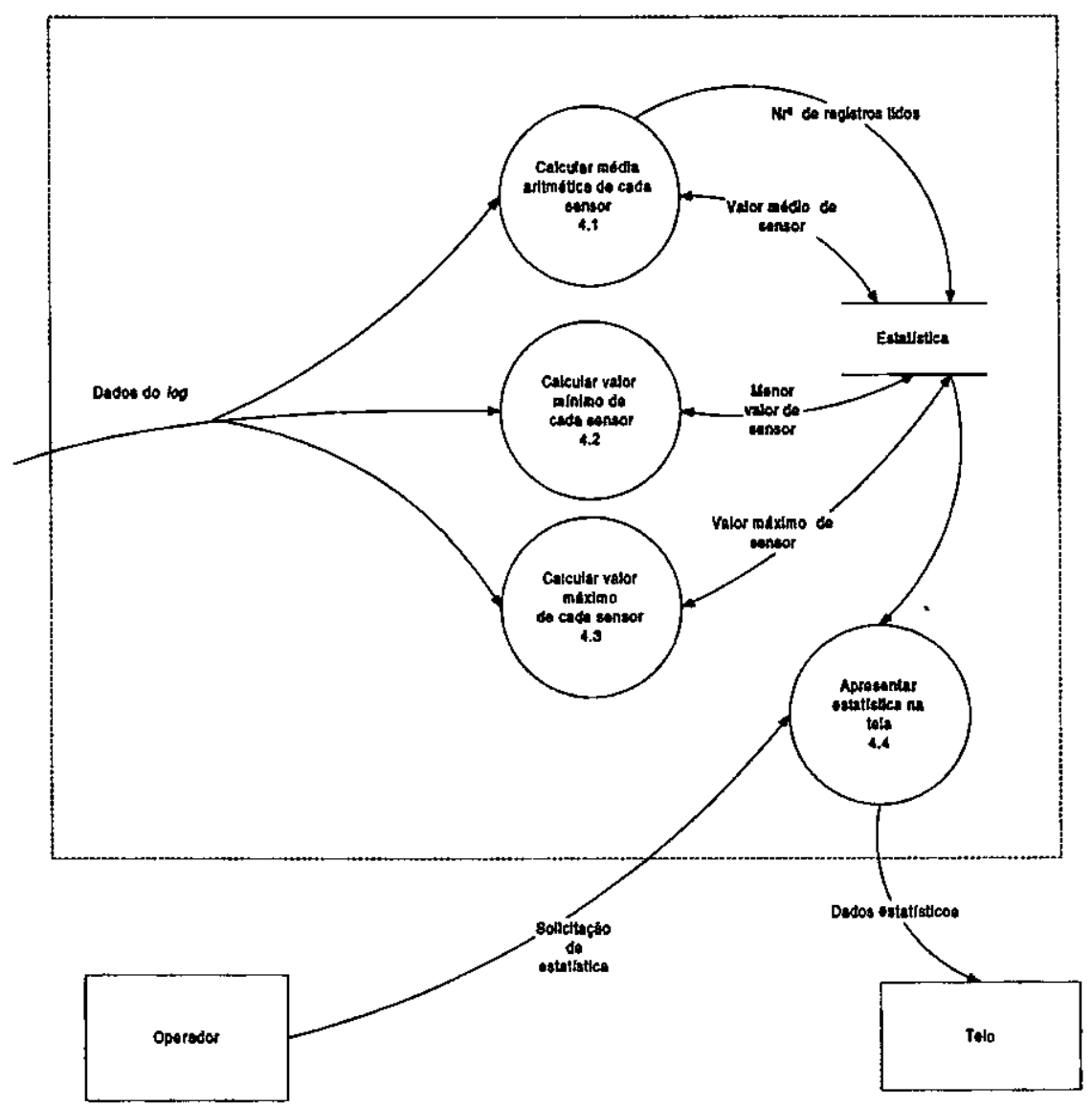

Figura 4.10 DFD 4 - Mostrar estatística do log.

O processo consiste em calcular o menor (figura 4.10 - processo 4.2), o maior (figura 4.10 - processo 4.3) e a média aritmética (figura 4.10 - processo 4.1) dos valores obtidos dos 
principais sensores presentes na aeronave. $O$ depósito de dados Estatística é uma estrutura que contém entradas para todos os sensores que são utilizados, de acordo com os requisitos funcionais apresentados na seção 3.4.1.

\subsubsection{DFD 5 - Visualizar as Imagens da Câmera Fotográfica}

Este módulo permite ao operador visualizar as imagens obtidas pela câmera fotográfica sem a necessidade de utilizar um outro editor de imagem, tais como Paint, ACDSee, etc.

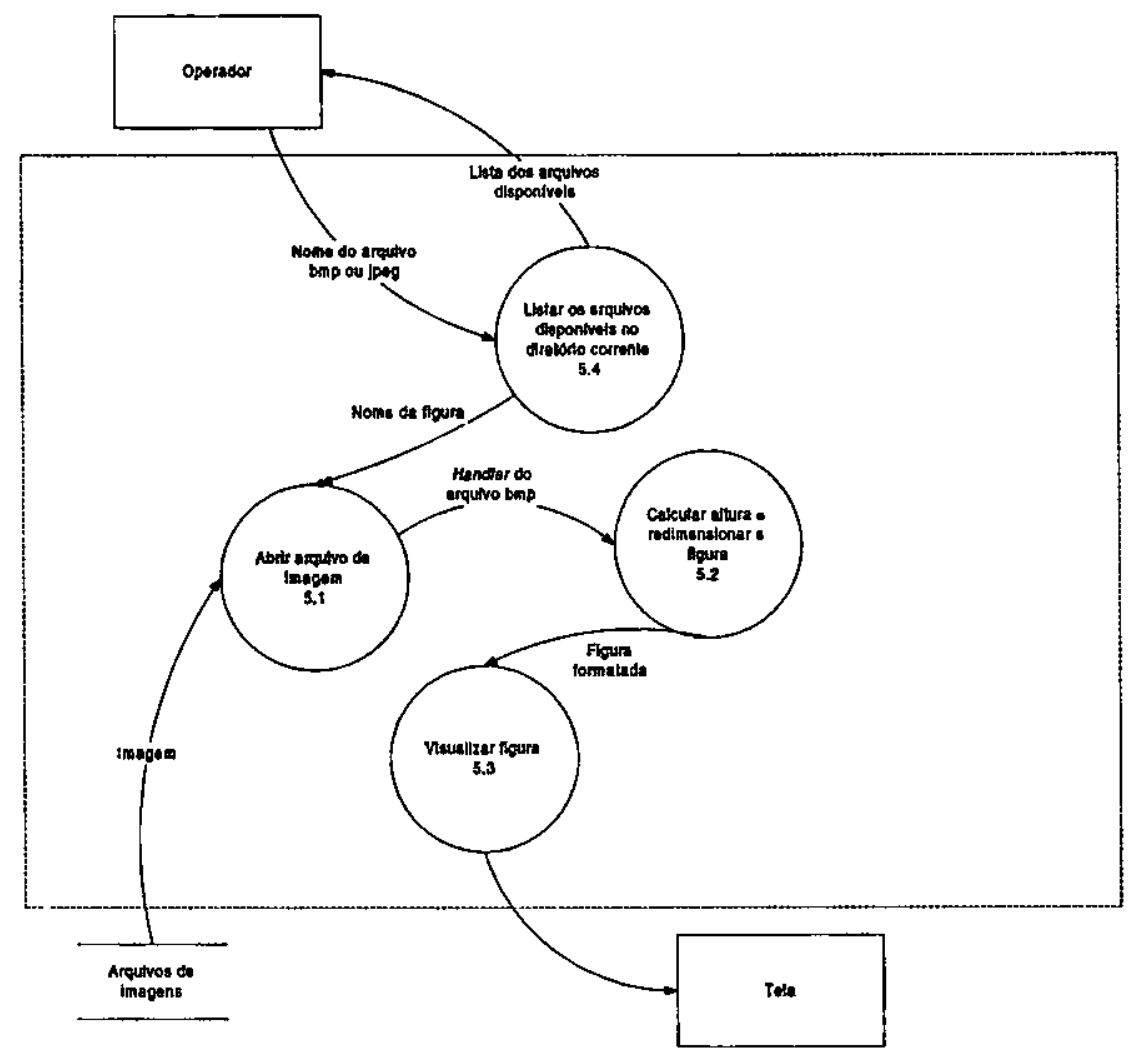

Figura 4.11 DFD 5 - Visualizar as imagens da câmera fotograficica.

O módulo obtém uma lista dos arquivos disponíveis no diretório corrente (figura 4.11 processo 5.4) disponibilizando-a para o operador em uma caixa de seleção, também conhecida como listbox. Esta função recebe o nome do arquivo selecionado pelo operador e o envia para a função Abrir Arquivo de Imagem (figura 4.11 - processo 5.1). Ap6s a imagem ser carregada e realizado um procedimento de ajuste da imagem, no caso desta ser maior que o quadro de visualização. Este ajuste consiste em reduzir a imagem para adequá-la ao quadro (figura 4.11 processo 5.2). Depois que a imagem foi transformada, a função Visualizar Figura (figura 4.11 processo 5.3) mostra a imagem na tela utilizando o objeto "painel de imagem". 


\subsubsection{DFD 6 - Gerar Painel de Telemetria}

Este módulo gera o painel da instrumentação do avião. A função Criar Instrumentos (figura 4.12 - processo 6.1) cria os instrumentos a partir de uma biblioteca de Mostradores (gauges). Quando o mostrador é criado, a função carrega um arquivo do tipo bmp que será o fundo do mostrador. Isto é feito pela função Carregar BMP dos Instrumentos (figura 4.12 processo 6.4). Com essa biblioteca é possível criar qualquer tipo de mostrador. $O$ fluxo de dados Instrumentos, definido no dicionário de dados, contém a lista dos instrumentos que são criados. A função Iniciar Instrumentos (figura 4.12 - processo 6.2), configura os instrumentos com os valores padrões de cada instrumento.

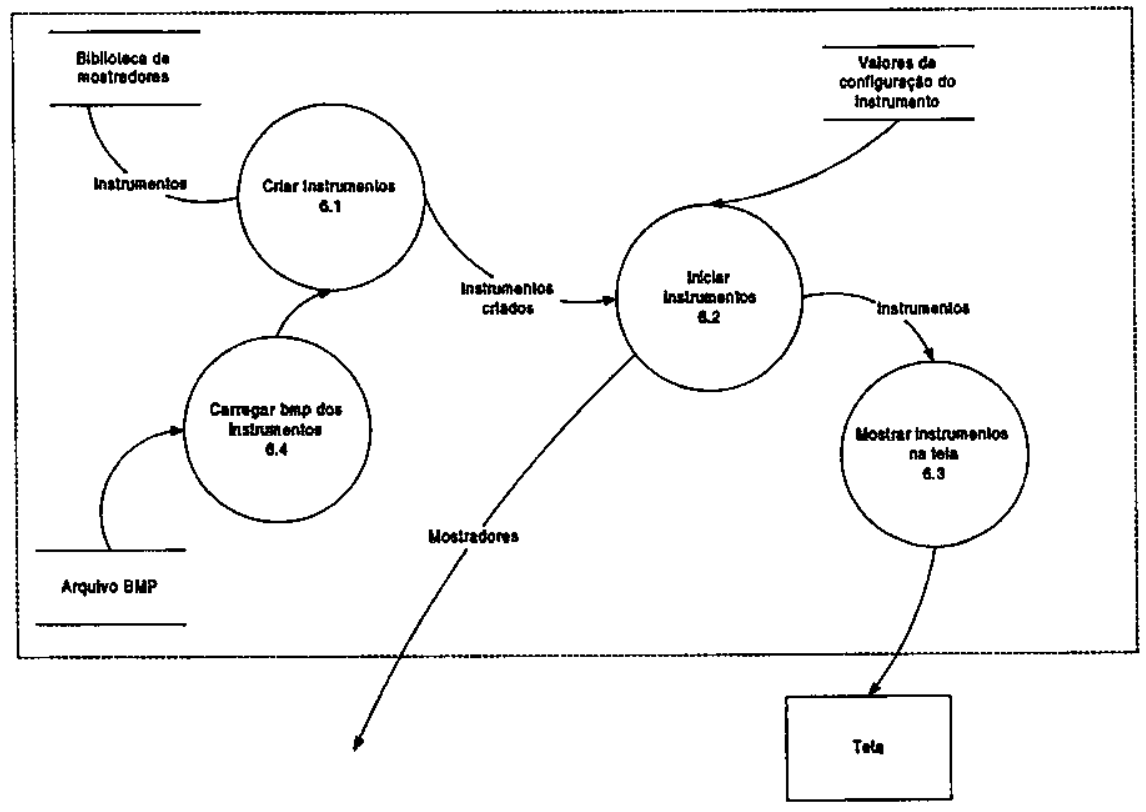

Figura 4.12 DFD 6 - Gerar painel de telemetria.

\subsubsection{DFD 7 - Selecionar Outro Painel de Telemetria}

Esta função permite ao operador selecionar o tamanho do painel entre os modos disponíveis (1/5 e 1/8 do tamanho da tela). O painel com 1/8 do tamanho da tela mostra os instrumentos em uma escala reduzida, com $60 \%$ do seu tamanho original. Os instrumentos que são apresentados neste painel são:

- Combustível;

- GPS;

- Nível de bateria do sistema; 
- Nível de bateria do receptor;

- Horizonte artificial.

\subsubsection{DFD 2.1 - Abrir Canal do Modem}

Esta função configura os parâmetros do modem e alguns parâmetros que são utilizados por outras funções do sistema. Antes de abrir o canal do modem, a função Editar Nome do Arquivo de $\log$ (figura 4.13 - processo 2.1.7) é executada. Esta função envia um fluxo de dados contendo o nome do arquivo para a função Criar Arquivo de $\log$ (figura 4.13 - processo 2.1.2).

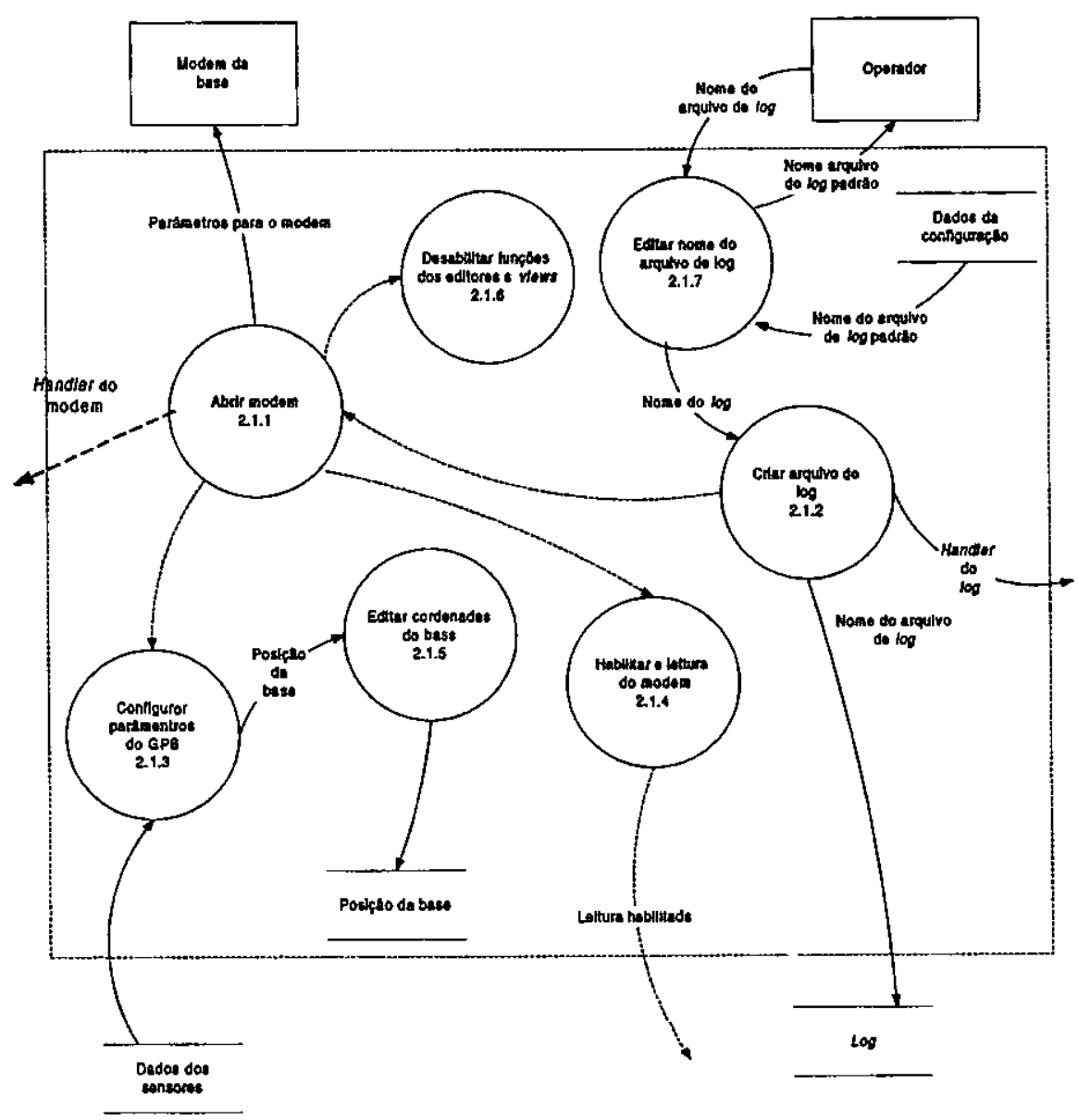

figura 4.13 DFD 2.1 - Abrir canal do modem.

Para economizar espaço em disco, o handler do Log gerado pela função Criar Arquivo de $\log$ (figura 4.13 - processo 2.1.2) é do tipo binário. Nenhuma função de banco de dados é usada para gerar, ou acessar o arquivo de log. 
A função Criar Arquivo de $\log$ (figura 4.13 - processo 2.1.2) envia um fluxo de controle para a função Abrir Modem (figura 4.13 - processo 2.1.1). Esta por sua vez, abre o modem enviando o fluxo Parâmetros para o Modem (definido no DD). Em seguida, a leitura do modem é habilitada com o envio de um fluxo de controle para a função Ler Dados da Porta Serial (figura 4.8 - processo 2.5 ).

A função Configurar Parâmetros do GPS (figura 4.13 - processo 2.1.3) abre uma caixa de diálogo onde são solicitadas as coordenadas de localização do computador da Estação Base. Estas coordenadas são utilizadas para realizar o cálculo de distância entre a Estação Base e a aeronave. Quando o canal está aberto, outras funções como o Visualizar as Imagens da Câmera Fotográfica (figura 4.11), e Mostrar Log (figura 4.10), devem ser desabilitadas, o que é realizado pela função Desabilitar Funções dos Editores e Views (figura 4.13 - processo 2.1.6).

\subsubsection{DFD 2.2 - Gravar Log dos Instrumentos}

Esta função grava a telemetria recebida pela Estação Base. A gravação do log é feita toda vez que os instrumentos são atualizados. Para isso é usado o handler do log gerado pela função Abrir Canal de Modem (figura 4.8 - processo 2.1). Para economizar espaço de disco, o fluxo Dados dos Sensores é reformatado pela função Formatar Dados (figura 4.14 - processo 2.2.2) realizando um casting ${ }^{2}$ sobre a estrutura.

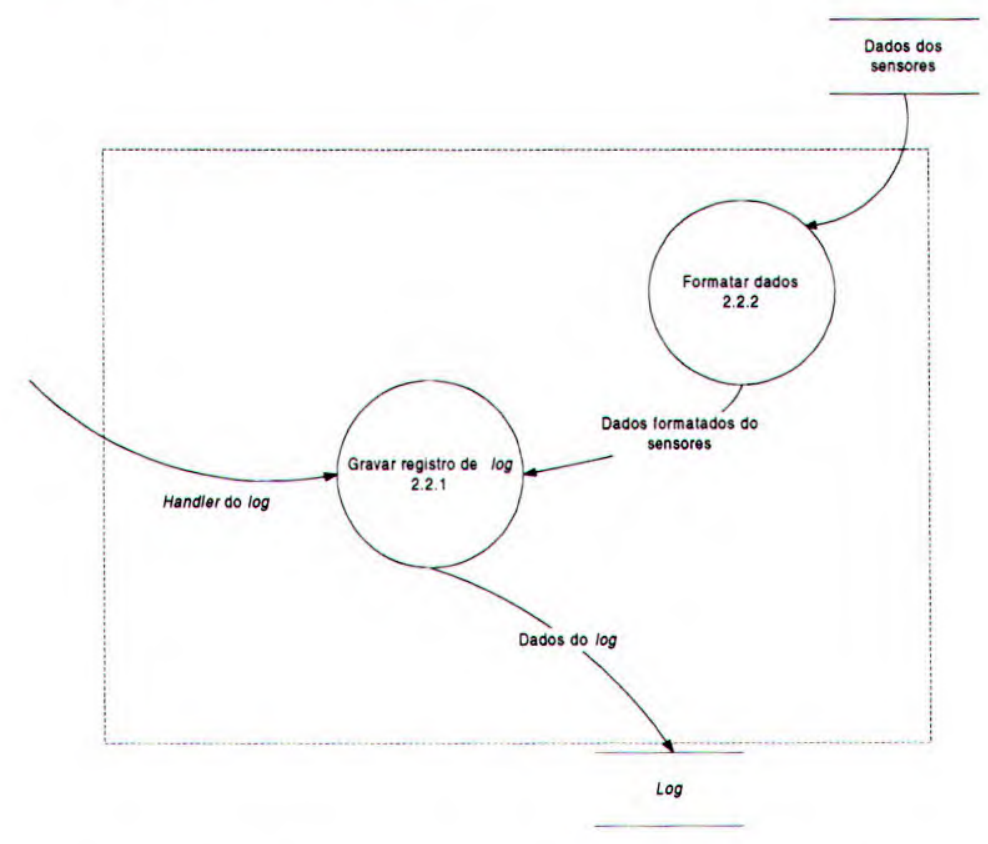

figura 4.14 DFD 2.2 - Gravar log dos instrumentos.

\footnotetext{
${ }^{2}$ Mudança do tipo do dado. Por exemplo, inteiro para byte
} 


\subsubsection{DFD 2.3 - Monitorar Combustível}

Esta função verifica o nível de combustível do tanque (figura 4.15 - processo 2.3.1). Sempre que o combustível se encontrar em nível crítico, um alarme visual é acionado. Como já descrito no requisito funcional de software, seção 3.4 .1 , a representação gráfica do combustível será representa entre 0 e 100 , de forma digital.

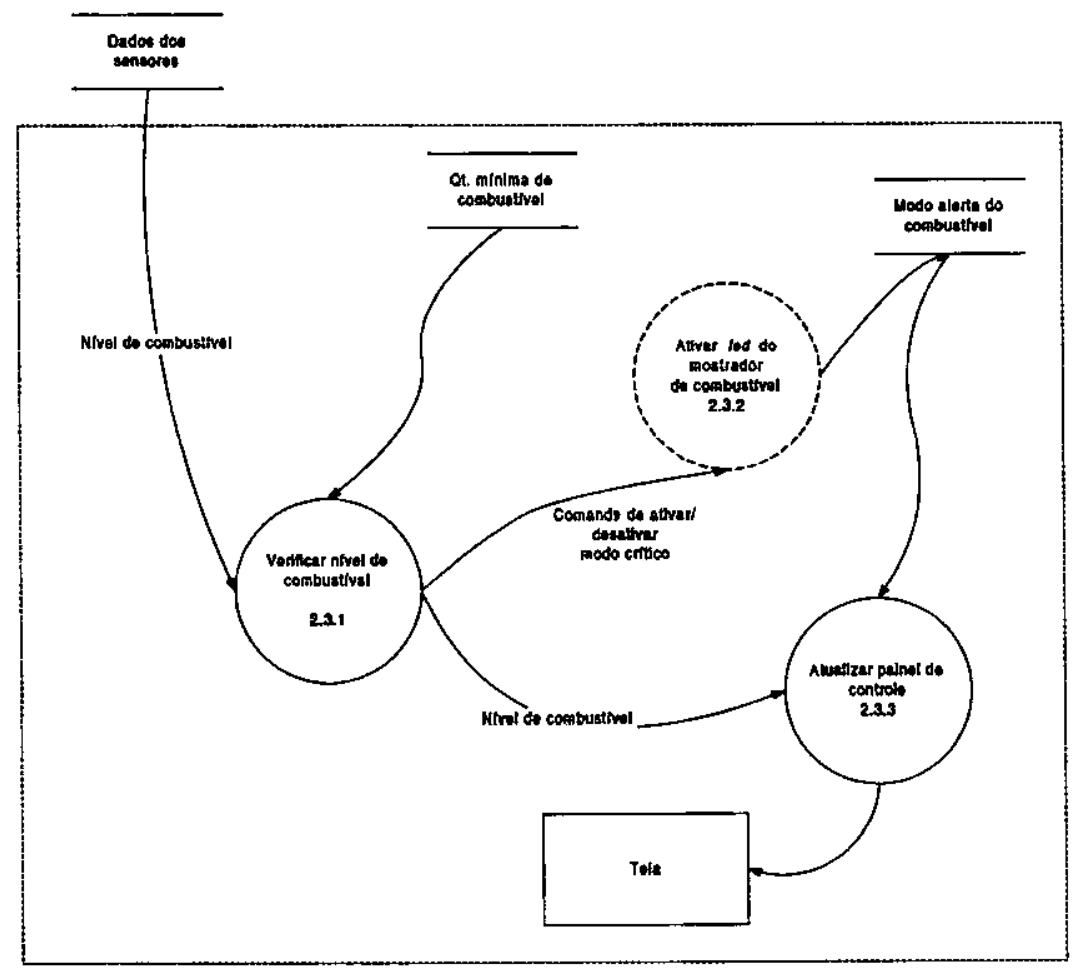

figura 4.15 DFD 2.3 - Monitorar combustível.

Para determinar se o tanque está em nível crítico, o depósito de dados Qt. Mínima de Combustível é consultada. Esta variável informa qual o nível que é considerado crítico, sendo o seu valor expresso em porcentagem. Se o Nível de Combustível for menor que Qt. Mínima a função Ativar Led do Mostrador de Combustível (figura 4.15 - processo 2.3.2) ativa um led no painel, informando o nível crítico do combustível.

\subsubsection{DFD 2.4 - Atualizar Instrumentos}

O papel desta função dentro do STT - MB é estratégico pois é a partir dela que várias outras funções são chamadas. O diagrama de fluxo de controle apresentado na seção 4.10 .1 figura 4.8, ilustra a interação deste módulo com os demais módulos envolvidos no processo de 
monitorização da instrumentação da aeronave.

Conforme foi definido nos requisitos funcionais, os instrumentos são atualizados em intervalos regulares de um segundo. A função Desempacotar Dados dos Sensores (figura 4.16 processo 2.4.3) lê a base de dados Pacote Pronto, representada por uma cadeia de caracteres, e a transforma em uma estrutura de dados chamada Dados dos Sensores. O layout de formatação dos campos foi apresentado na seção 2.4.5.

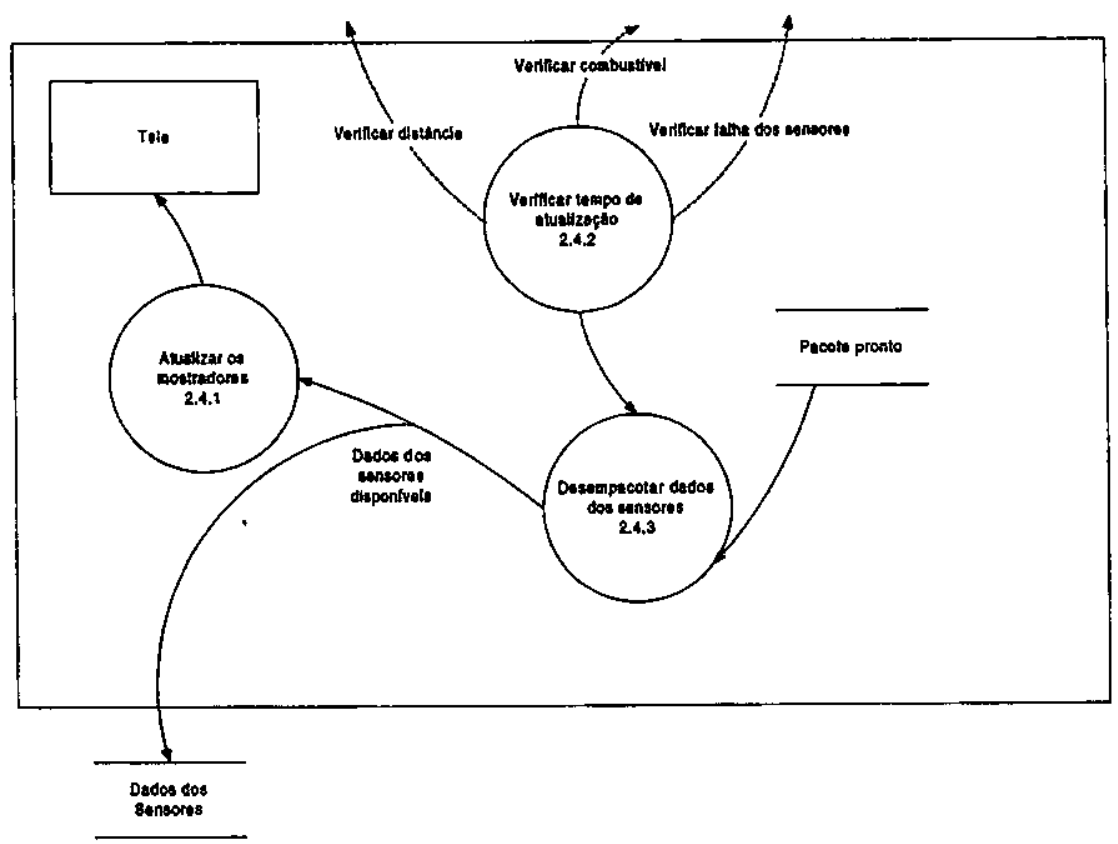

Figura 4.16 DFD 2.4 - Atualizar instrumentos.

Quando os dados estão disponíveis, é invocada uma função para atualizar os instrumentos no painel do avião e em seguida são executadas as funções Reportar Falha dos Sensores (figura 4.8 - processo 2.7), Verificar Distância da Estação Base (figura 4.8 - processo 2.6) e Monitorar Combustível (figura 4.8 - processo 2.3).

\subsubsection{DFD 2.5 - Ler Dados da Porta Serial}

Esta função realiza o protocolo de enlace de dados do sistema, lendo os pacotes através da porta serial. A função Ler a Porta Serial (figura 4.17 - processo 2.5.1) lê continuamente a porta e armazena os dados obtidos em uma variável temporária chamada Bloco para Validação. Durante o processo de leitura, a função procura pelos caracteres de controle (CC) definidos no protocolo de comunicação. Quando a rotina localiza um CC, é verificado se o mesmo é um 
caractere de controle ou um caractere de dado. Uma vez que o caractere seja de controle, a função Recompor Pacote (figura 4.17 - processo 2.5.2) é chamada para verifica o bloco que está disponível. Nesta função é verificado se o tamanho do bloco corresponde ao tamanho definido no protocolo de comunicação.

Em um passo seguinte, é verificado o check-sum. A soma dos caracteres do bloco deve conferir com o check-sum do pacote (figura 4.17 - processo 2.5.3). Caso contrário, o bloco é descartado e uma nova recomposição do bloco é iniciada.

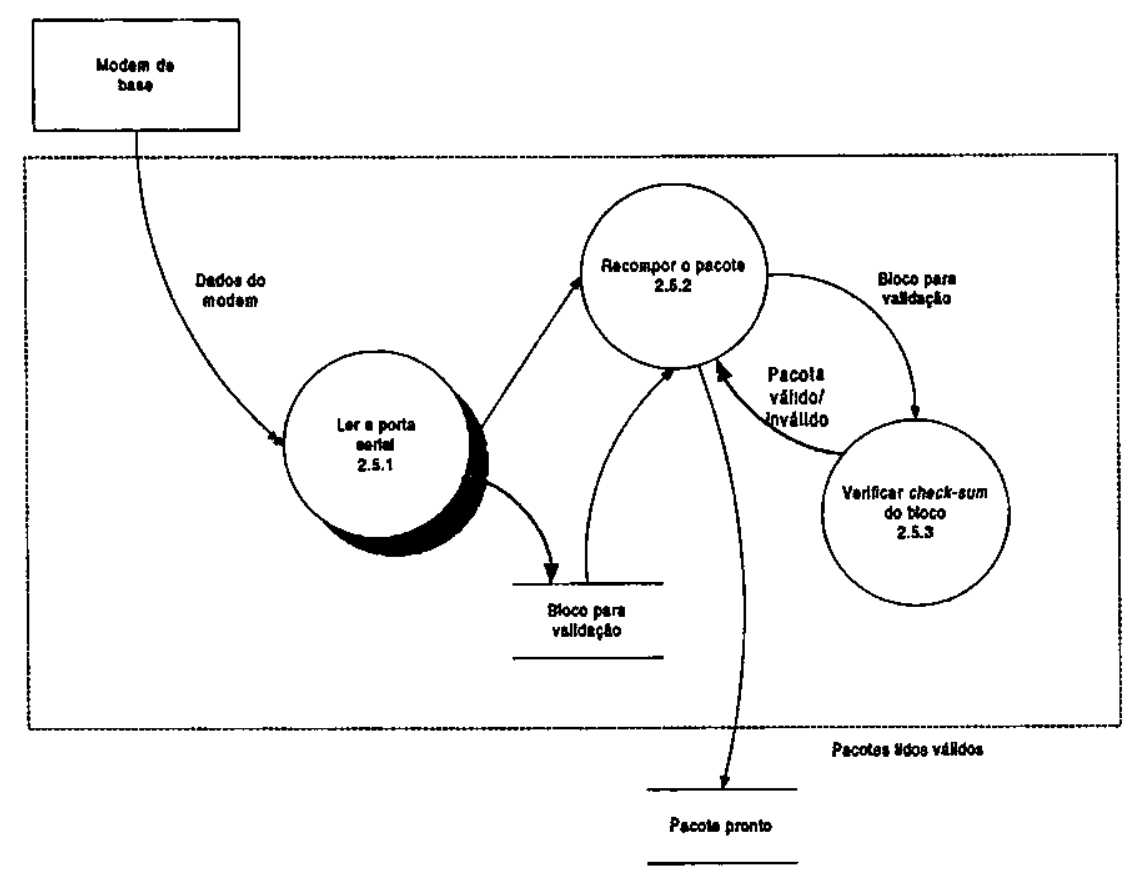

Figura 4.17 DFD 2.5 - Ler dados da porta serial.

\subsubsection{DFD 2.6 - Verificar Distância da Estação Base}

Esta função monitora a distância entre o computador da Estação Base e a aeronave. Todas as vezes que aeronave está próxima de sair do alcance do rádio o sistema ativa um indicador luminoso e emite um aviso sonoro ao operador.

Para verificar a distância é necessário saber a posição do computador da Estação Base e da aeronave. Com esses dados, a equação 1 fornece a distância entre dois pontos [LET98][LOG92]: 


$$
d=2 \times \operatorname{ArcSin}\left(\sqrt{\left(\frac{\operatorname{Sin}(\text { Lat } 1-\text { Lat } 2)}{2}\right)^{2}+\operatorname{Cos}(\text { Lat } 1) \times \operatorname{Cos}(\text { Lat } 2) \times\left(\frac{\operatorname{Sin}(\text { Long } 1-\text { Long } 2)}{2}\right)^{2}}\right)
$$

Equação 1 Distância entre dois pontos através das coordenadas do GPS (a).

Também é possível calcular a distância utilizando a equação 2, entretanto a mesma tem pouca precisão para distâncias pequenas [LET98].

$$
d=\operatorname{ArcCos}(\operatorname{Sin}(\operatorname{Lat} 1) \times \operatorname{Sin}(\text { Lat } 2)+\cos (\text { Lat } 2) \times \cos (\text { Long } 1-\text { Long } 2))
$$

Equação 2 Distância entre dois pontos (b).

As equações 1 e 2 não levam em consideração a altitude da aeronave. A equação 3 resolve este problema, porém, ela somente pode ser aplicada para pequenas distâncias pois o resultado fornecido pela equação 3 é uma reta, não levando em considerando a curvatura da terra. A equação 3 pode ser aplicada ao projeto uma vez que o requisito de operação do sistema é de $15 \mathrm{~km}$.

$$
D=\sqrt{(\text { Altitude } 1-\text { Altitude } 2)^{2}+d^{2}}
$$

\section{Equação 3 Para calcular a distancia em um espaço 3D}

A posição da Estação Base é obtida através da função Obter Posição da Estação Base (figura 4.18 -processo 2.6.2) que lê a variável de ambiente Posição da Base, que foi configurada pela função Abrir Canal do Modem (figura 4.8 - processo 2.1). A função Analisar e Calcular a Distância (figura 4.18 - processo 2.6.3), calcula a equação 3 e verifica se a distância é maior ou igual ao perímetro de alcance. Caso seja, o sistema envia um fluxo de controle para a função Ativar Indicador Luminoso (figura 4.18 - processo 2.6.4), e esta por sua vez, ativa no painel um indicador luminoso de alerta ao operador. Se a aeronave voltar para o perímetro seguro, o indicador de alertar é desativado. 


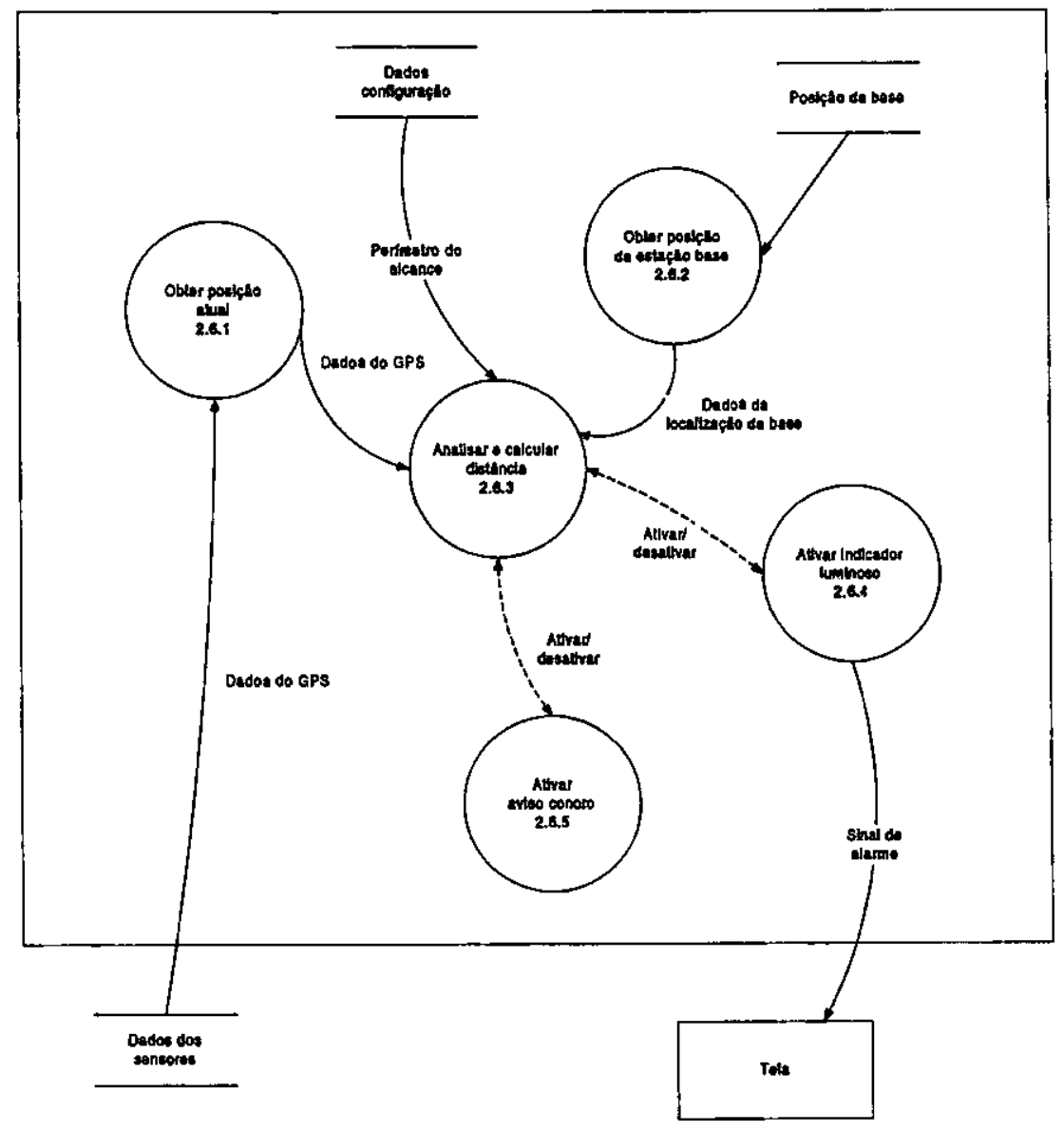

Figura 4.18 DFD 2.6 - Verificar a distância da Estação Base.

\subsubsection{DFD 2.7 - Reportar Falha dos Sensores}

Esta função avalia a operação dos sensores durante uma sessão de vôo. Para realizar tal análise, a função consulta a base de dados Valores dos Sensores Defeituosos, disponível no arquivo de configuração do sistema. Essa base de dados contém quais valores representam falhas nos sensores e estes valores estão definidos no dicionário de dados apresentado no Apêndice A.

Os dados lidos dos sensores são comparados com os dados que representam falhas nos sensores (figura 4.19 - processo 2.7.3). Se for detectada uma falha de algum sensor, o sistema dispara um aviso sonoro, ativa um led (figura 4.19 - processo 2.7.4) e reporta um fluxo de dados chamado Lista dos Sensores que Falharam. Cada sensor tem um led no painel representando o seu estado de funcionamento. A função Atualizar Led dos Sensores que Falharam (figura 4.19 processo 2.7.5), realiza a checagem nos dados dos sensores e atualiza os leds. 


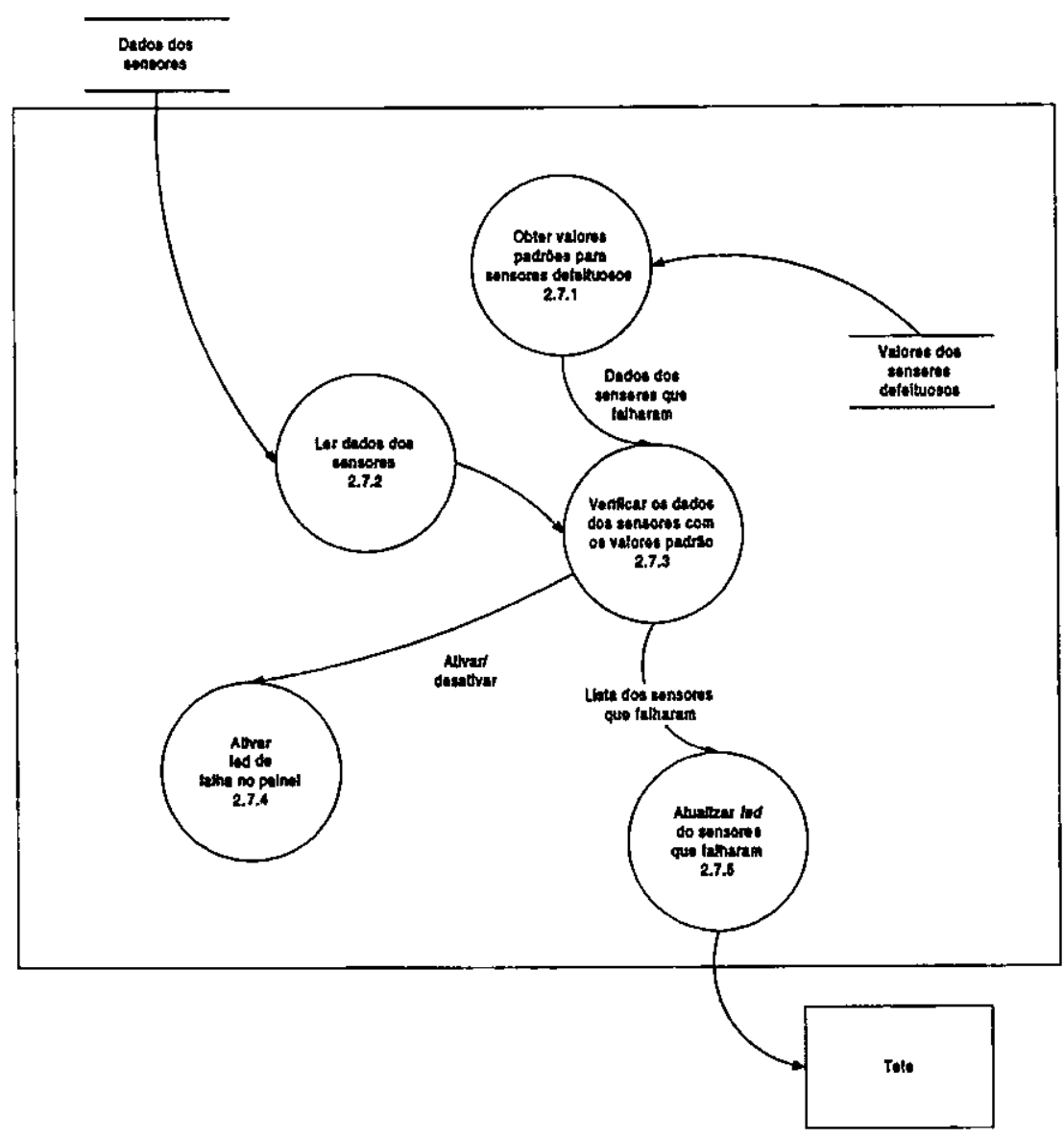

Figura 4.19 DFD 2.7 - Reportar falha dos instrumentos.

\subsubsection{DFD 2.8 - Fechar Modem}

Esta função encerra a conexão entre a aeronave e a Estação Base. Para fechar o canal do modem, uma caixa de diálogo é aberta solicitando a confirmação do operador. Este procedimento é executado pela função Fechar Modem (figura 4.20 - processo 20.1). Após a confirmação, o arquivo de $\log$ é fechado (figura 4.20- processo 20.2) e as opções de visualizar $\log$ e visualizar imagens são habilitadas.

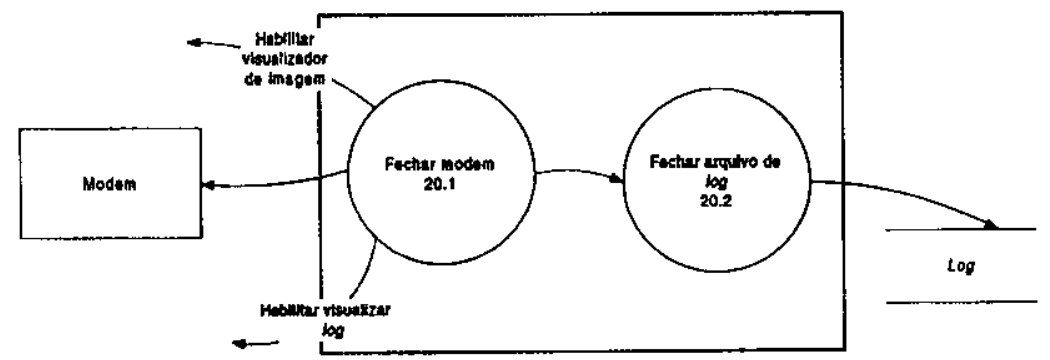

Figura 4.20 DFD 2.8 - Fechar modem. 


\subsubsection{DFD 2.9 - Atualizar as Imagens de Vídeo}

Esta função está disponível no driver de captura da placa de TV instalada no computador da Estação Base. Ela captura as imagens da placa de TV para serem mostradas em modo de overlay. A função Receber Imagem (figura 4.21 - processo 2.9.1) é realizada por uma biblioteca de captura de vídeo. A biblioteca trata do gerenciamento de quadros e da estabilizaçăo das imagens. O painel da instrumentação sobrepõe as imagens capturadas pela biblioteca.

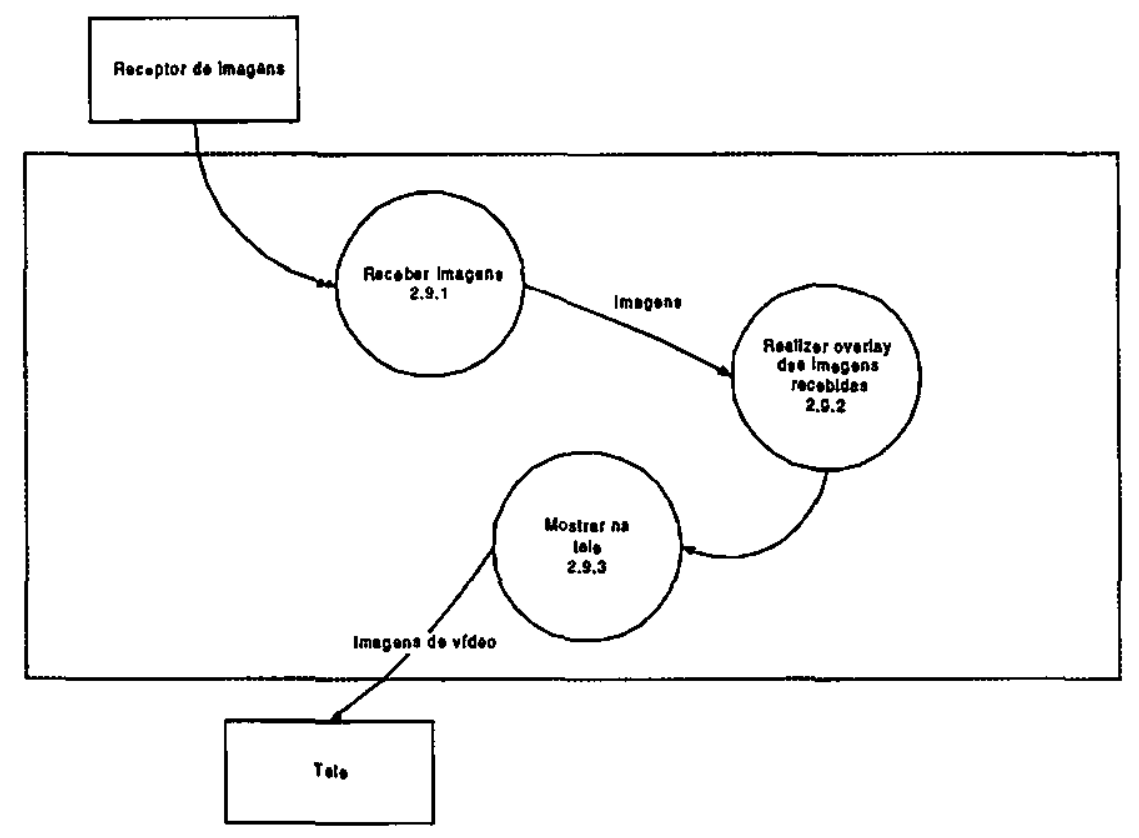

Figura 4.21 DFD 2.9 - Atualizar as imagens de vídeo.

\subsubsection{DFD 1.1 - Coletar Dados dos Sensores}

O papel deste módulo é coletar os dados que são enviados de forma assíncrona pelos sensores através da rede $\mathrm{I}^{2} \mathrm{C}$, implementada utilizando a porta paralela do computador da aeronave.

A função Ler Dados na Rede $I^{2} \mathrm{C}$, (figura 4.22 - processo 1.1.1), é implementada por um processo concorrente e todos os dados lidos são enviados para a função Marcar a Resposta do Sensor (figura 4.22 - processo 1.1.3). Esta função armazena os dados lidos na Tabela dos Sensores e registra a quantidade de vezes que cada sensor foi lido.

A cada 0,5 segundo, a função Gerar Dados dos Sensores Válidos (figura 4.22 processo 1.1.2), implementada por um processo concorrente, lê a Tabela dos Sensores e atualiza 
o depósito Dados Sensores. Esta por sua vez, invoca a função Atualizar a Última Leitura dos Sensores (figura 4.22 - processo 1.1.4), para marcar a contagem da última leitura que ocorreu nos sensores. Esta informação é guardada no depósito Dados dos Sensores.

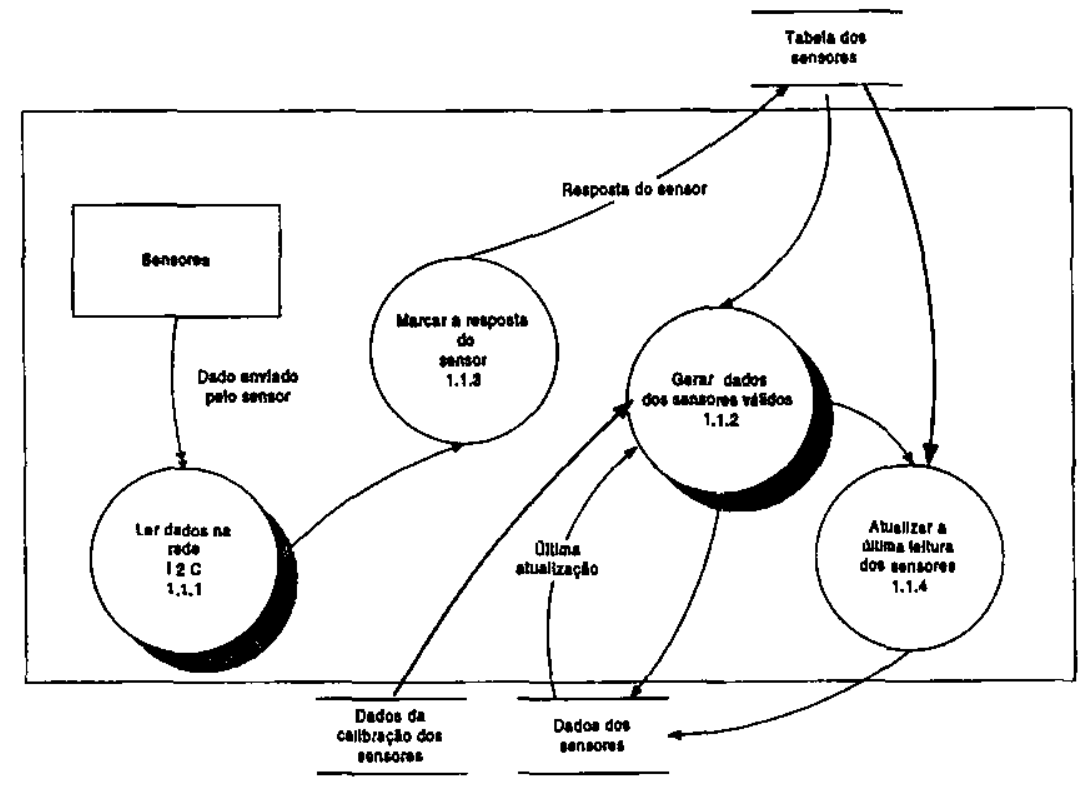

Figura 4.22 DFD 1.1 - Coletar dados dos sensores.

Para detectar se um sensor está funcionando, a função Gerar Dados dos Sensores Válidos (figura 4.22 - processo 1.1.2), verifica na tabela de sensores se o número de vezes que o sensor foi lido é maior que o número da última leitura marcada no depósito Dados dos Sensores. Se as duas leituras são iguais, então o sensor não respondeu durante o intervalo de 0,5 segundo. Quando isto ocorre, a função configura o dado do sensor com o valor correspondente à falha.

Antes dos dados dos sensores serem armazenados, a função Gerar Dados dos Sensores Válidos realiza a calibração dos dados efetuando as correções necessárias sobre o mesmo. Os dados de calibração estão no depósito Dados de Calibração dos Sensores. A calibração é realizada durante a operação de autoteste.

\subsubsection{DFD 1.2 - Transmitir Dados para Porta Serial da Aeronave}

Este módulo transmite os dados para o modem. A função Montar Pacote Para Transmissão (figura 4.23 - processo 1.2.1), prepara um pacote conforme o protocolo de comunicação especificado na seção 2.4.5. A estrutura a ser transmitida é enviada para a função 
Verificar Check-sum do Pacote (figura 4.23 - processo 1.2.2), onde é gerado um byte extra para a validação do bloco, que é inserido no final do bloco a ser transmitido.

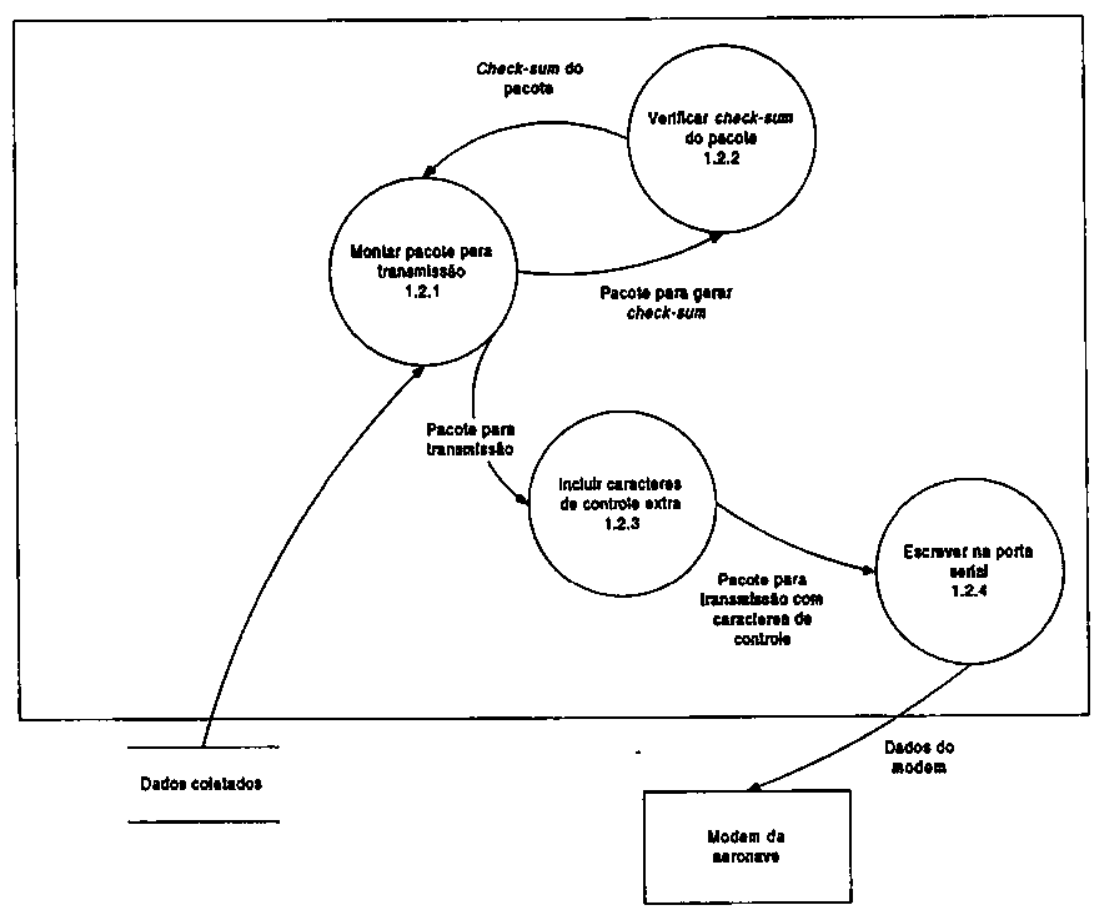

figura 4.23 DFD 1.2 - Transmitir dados para a porta serial.

A função Incluir Caractere Extra (figura 4.23 - processo 1.2.3), recebe o fluxo de dados Pacote para Transmissão. Esta função replica todo caractere que seja igual ao caractere de controle. Isto evita que o STT - MB reconheça o caractere como sendo um caractere de controle.

\subsubsection{DFD 1.3 - Realizar Autoteste nos Sensores}

Quando o sistema STT - MA é executado, um procedimento de autoteste e calibração é realizado. Em seguida, a função Coletar Dados dos Sensores (figura 4.6 - processo 1.1) é iniciada. Esta função lê o depósito Dados dos Sensores e compara os valores lidos com os valores correspondentes à falha de cada sensor. Se o sensor falhar, a função Reportar Falha para o LCD listará seqüencialmente todos os sensores que falharam e ao mesmo tempo será emitido um aviso sonoro. Após este teste, o sensor de pressão e o receptor GPS são calibrados. 


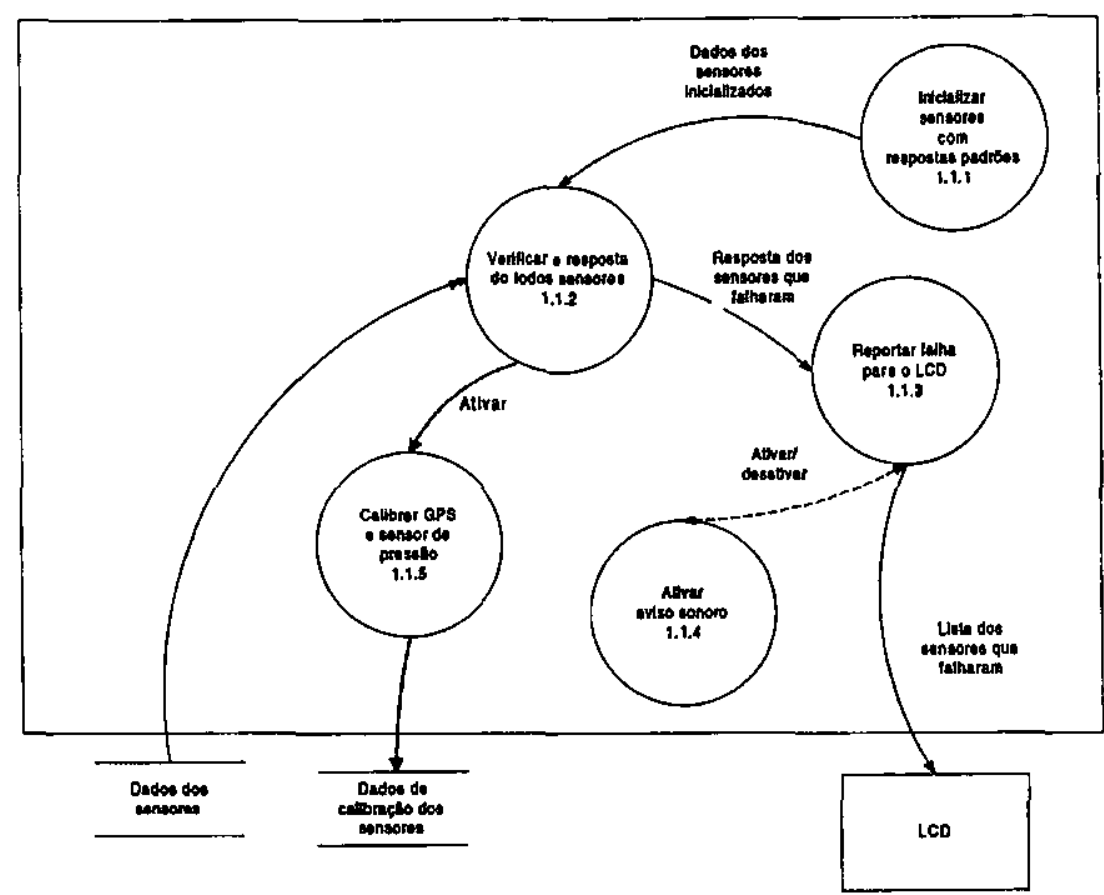

figura 4.24 DFD 1.3 - Realizar autoteste nos sensores.

\subsection{Considerações finais}

A especificação e o projeto do sistema STT foram apresentados neste capítulo. Foram especificados detalhes do comportamento do sistema em diversas situações. A especificação dos processos foi baseada em uma lista de eventos. Foram descritos todos os processos e a partir deles foi gerado o dicionário de dados do sistema que pode ser encontrado no Apêndice $\mathrm{A}$. Todas as descrições feitas foram acompanhadas de DFDs para melhor compreensão e documentação do STT.

No próximo capítulo é descrita a implementação do sistema, mencionando-se os objetos e procedimentos implementados no STT. 


\section{Capítulo 5}

\section{Projeto e Implementação do STT}

\subsection{Considerações Iniciais}

Neste capítulo são apresentados detalhes da implementação do STT. Na seção 5.2, são apresentados os detalhes da implementação do STT - MA (Módulo Aéreo) e STT - MB (Módulo Base). A construção do software foi modularizada com a finalidade de facilitar a manutenção do sistema e a sua migração para outras linguagens de programação dentro do ambiente Windows. Nesta seção, também é fornecida uma visão da estratégia adotada na construção do STT - MA e MB. Na seção 5.3, são apresentados os testes de software que foram realizados sobre o sistema para a sua validação. Na seção 5.4, são apresentadas as interfaces do sistema. Finalmente, na seção 5.5 , são apresentadas as considerações finais deste capítulo.

\subsection{Implementação de Software}

Como já citado anteriormente, o sistema foi divido em dois módulos: STT - MA e STT - MB. Devido a restrições de hardware e facilidade de implementação, foram adotados sistemas operacionais distintos em cada módulo. O STT - MB é executado sobre o sistema operacional Windows 98 e o STT - MA é executado sobre o sistema operacional Linux. A distribuição adotada do Linux é a Mulinux [MUL99], kernel 2.2.15.

As rotinas do STT - MA foram implementadas na linguagem de programação C, utilizando o compilador gcc+e as rotinas do STT - MB foram implementadas em Delphi 4.0 [BOR98]. A escolha do Delphi é justificada pela facilidade de desenvolvimento de aplicações 
gráficas e pela grande disponibilidade de bibliotecas VCL (Visual Component Library), também chamadas de classes de componentes visuais [CAN96], disponíveis na Internet. O Delphi facilita o desenvolvimento de software não permitindo que ponteiros tenham acesso a áreas não autorizadas na memória, evitando erros do tipo segmentation fault [CAN96]. O Delphi 4.0 apresenta um ambiente excelente para o paradigma de programação orientada a objeto.

Para acelerar o processo de construção do STT - MB foram utilizados controles OCX (Custom Control), uma solução padronizada para o software de componentes fornecida pela Microsoft. Os OCX, também conhecidos por Controles ActiveX, são implementados usando-se a tecnologia de OLE 2.0 (Object Linking and Embedding) [FAR97]. Estes controles são dependentes da MFC (Microsoft Foundation Classes) [FAR97] e podem ser desenvolvidos em C++ Visual, Delphi, Borland C 5.0, e em Visual Basic 6.0. A versão MFC utilizada no sistema é a 4.2.5. Os componentes OCX podem se integrar ao browser Internet Explorer, e segundo Farrar [FAR97], os OCX deveriam ser concorrentes da tecnologia JAVA.

Os mostradores gerados no STT - MB foram implementados utilizando-se uma biblioteca de Gauges (controles OCX) distribuída pela Global Majic [GLO99]. Através desses gauges é possível construir qualquer tipo de mostrador. Uma biblioteca adicional foi utilizada para criar instrumentos específicos do avião, também da Global Majic.

Um componente OCX foi utilizado para capturar as imagens captadas pela placa de TV. Este OCX é produzido pela Vídeo Lab [VID98]. Com este componente é possível, por exemplo, selecionar a fonte de imagem, trocar o padrão de imagem NTSC/PAL, selecionar o modo de exibição, número de quadros, etc.

\subsubsection{Arquitetura de Implementação do STT - MB}

Para a implementação do STT - MB, definiu-se uma abordagem com três camadas: Visual, Funcional e Kernel. A figura 5.1 mostra a relação entre elas.

Definiu-se que a Camada Visual seria a interface onde são exibidos os mostradores, os botões e as caixas de texto. A Camada Funcional realiza toda a validação e consistência dos dados recebidos pela Camada Visual. As transações de arquivos e operações com o kernel são realizadas na Camada Kernel.

Esta abordagem sistêmica proporciona um maior grau de modularização do sistema. Assim, se no futuro for necessário atualizar ou mesmo substituir o controle visual ou o OCX de 
leitura da porta serial, por exemplo, somente o componente deverá ser substituído sem nenhuma modificação na interface das camadas.

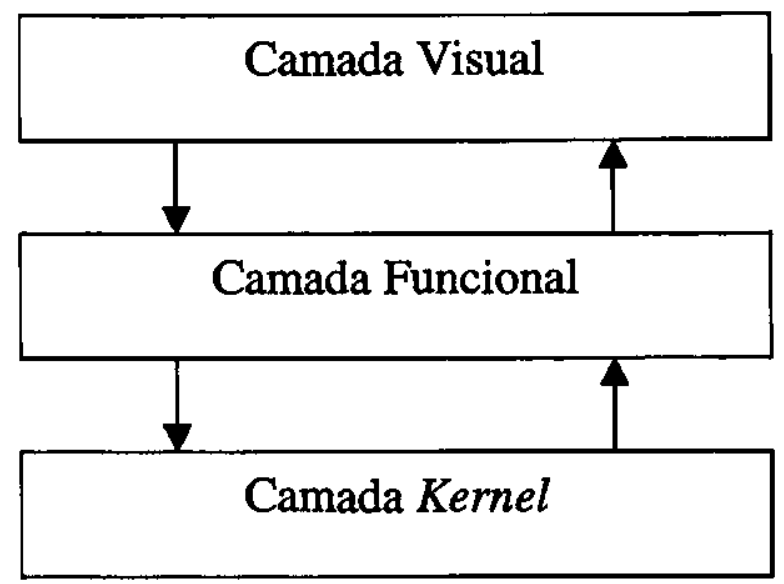

Figura 5.1 Modelo de implementação para o STT - MB.

Para a implementação do STT - MB foi utilizado o paradigma de programação orientada a objetos. O diagrama ilustrado na figura 5.2 mostra a definição e a relação existente entre as principais classes do STT - MB. 


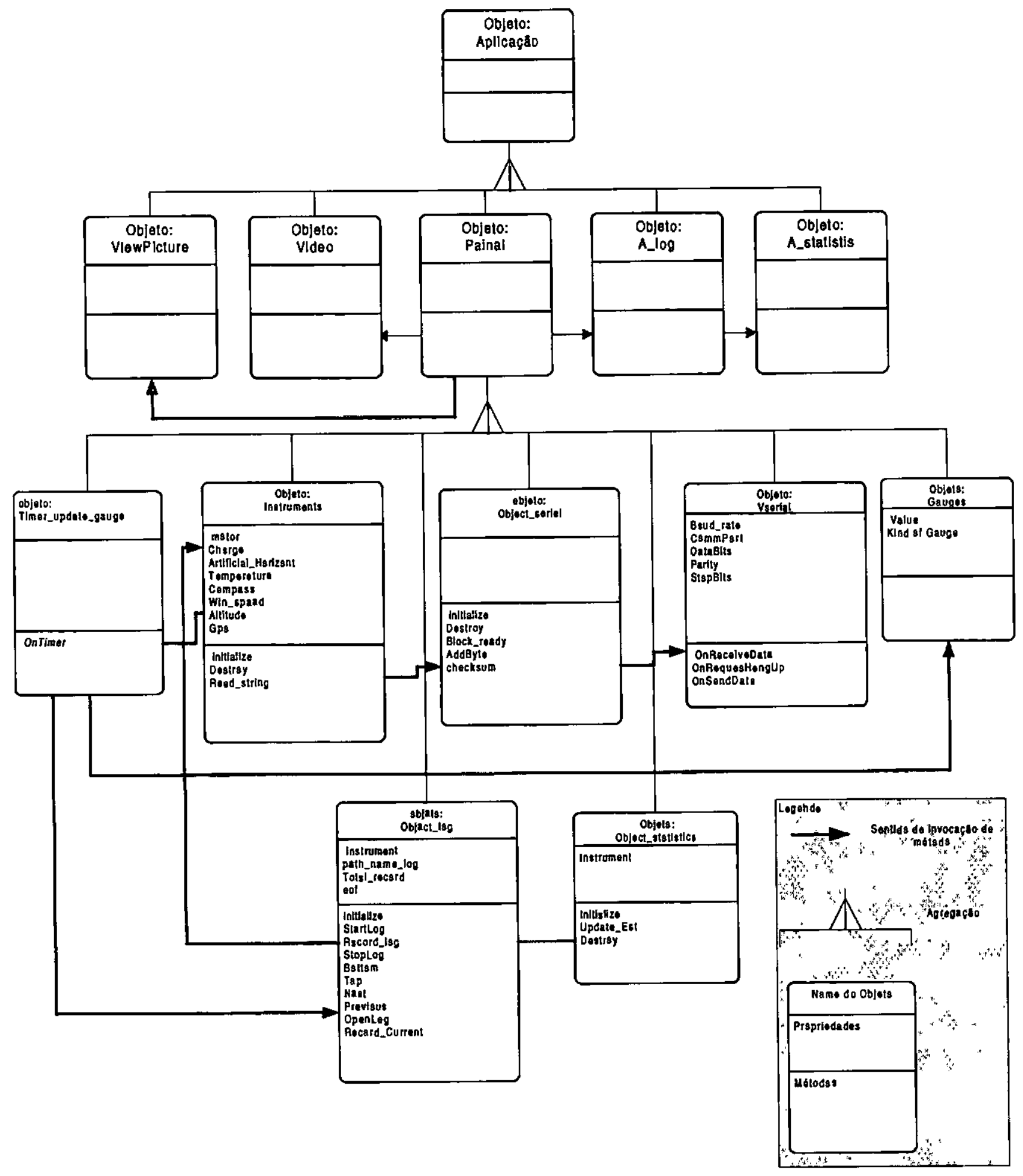

Figura 5.2 Diagrama dos objetos do sistema do STT - MB.

\subsubsection{Descrição dos Objetos do STT - MB}

Nesta seção, são descritos os objetos utilizados pelo STT - MB. São citados os 
métodos públicos de cada objeto e a sua relação com os demais objetos do sistema. Objetos visuais, tais como botões, painéis e formulários não são descritos.

\section{Objeto Vserial}

Dentro do modelo de implementação adotado este objeto se encontra dentro da Camada Kernel e interage com a porta serial enviando e recebendo dados. Criado através da classe TVSSComm32, esta VCL é distribuída livremente por Cheers [CHE99]. Conforme definido no protocolo de enlace de dados, seção 2.4.5, os parâmetros de configuração do modem são: 2400/8/N/1. Abaixo são descritas as principais propriedades desse objeto:

- Baude_rate: Taxa de transmissão para a porta serial;

- CommPort: Nome da porta serial que será enviado os dados;

- Parity: Transmissão com paridade;

- DataBits: Quantidade de Bits transmitidos.

Os eventos e métodos disponiveis para esta classe são:

- OnreceiveData: evento executado sempre que existe dados disponíveis na porta serial. O evento fomece como parâmetro de saída uma variável contendo um ponteiro para o buffer da porta serial $\mathrm{e}$ um outro informando o tamanho do buffer;

- OnRequestHangUp: evento executado quando ocorre um HangUp na porta serial;

- WriteCommData: método utilizado para escrever dados na porta serial. Para executar a escrita é necessário fornecer um buffer do tipo char e informar o tamanho do mesmo.

Quando o evento OnreceiveData é executado os dados são transferidos para o Objeto Serial.

\section{Objeto Serial}

Situado na Camada Funcional, este objeto realiza a validação dos dados recebidos pelo objeto Vserial e transformando-os em um pacote de dados válido, também chamado de Bloco Pronto, como visto no DFD 2.5, seção 4.10.11. Criado através da classe TdataSerial, o objeto 
Serial possui somente métodos. São eles:

- Initialize: Configura as variáveis privadas de controle de um pacote válido;

- Block_ready: Retorna um bloco válido. O bloco corresponde ao protocolo de enlace de dados definido na seção 2.4.5;

- Add_byte: Adiciona byte ao bloco a ser validado. Durante o processo de adição, é verificado se o byte não é um caractere de controle. Caso seja, é executada a função Check-Sum para verificar a consistência do bloco;

- Check_Sum: Verifica a integridade de um bloco. Recebe como parâmetros o bloco e o caractere de check-sum colocado no pacote. Se o bloco for válido, é retornado verdadeiro. Caso contrário, é retornado falso.

O objeto Serial trabalha como uma interface entre o objeto Instruments e o objeto Vserial. Isto torna o sistema altamente manutenível. Havendo a necessidade de substituição do objeto que trabalha com a porta serial, nenhuma modificação será necessária, além do próprio objeto substituído.

O pacote validado pelo objeto Serial fica disponível para ser desempacotado pelo objeto Instruments.

\section{Obieto Instruments}

Situado na Camada Funcional, o objeto Instruments realiza o desempacotamento de um Pacote Válido, citado no DFD 2.4, seção 4.10.10, e atualiza os dados dos sensores. Ele é criado através da classe Tdata_Instruments com as seguintes propriedades:

- Motor: Estrutura do tipo Tmotors que contém as propriedades de temperatura do motor, rotação;

- Charge: Estrutura do tipo Tcharge que contém as propriedades de carga de bateria da instrumentação e do $\mathrm{R} / \mathrm{C}$;

- Artificial_Horizon: Estrutura do tipo Thoriz_artificial que contém as propriedades de arfagem e rolagem;

- Temperature: Estrutura do tipo Ttemp que contém as propriedades da temperatura externa e dos gases do escapamento;

- Compass: Propriedade que indica o norte magnético;

- Win_speed: Propriedade que indica a velocidade do vento; 
- Altitude: Propriedade que indica a altitude da aeronave;

- GPS: Estrutura do tipo TGPS que contém as propriedades de latitude, longitude, altitude, velocidade e tempo;

Os tipos que compõem cada variável estão descritos no dicionário de dados, Apêndice A. Os métodos deste objeto são os seguintes:

- Initialize: Configura as variáveis de controle dos instrumentos;

- Read_string: Lê um pacote válido e o transforma em dados para as propriedades do objeto Instruments.

O objeto Instruments lê o pacote válido, fornecido pelo objeto Serial e o transforma em dados. Após a transformação, os dados dos sensores ficam disponíveis para serem usados pelos objetos visuais, neste caso os mostradores. O objeto Timer_Update_Gauge realiza este elo entre os dois objetos.

\section{Objeto Timer Update Gauge}

O objeto Timer_Update_Gauge é um objetò nativo da linguagem Delphi. As suas propriedades são

- Enable: Habilita ou desabilita o Timer;

- Interval: Tempo em milisegundos que será executado o evento OnTimer.

Para este objeto só existe o evento OnTimer. Conforme especificado nos requisitos funcionais, seção 3.4.1, a propriedade Interval foi configurada para disparar a cada 1000 milisegundos. Dentro deste evento, é invocado o procedimento do formulário chamado Update_Gauge, que realiza a transferência dos dados dos instrumentos, contidos no objeto Instruments, para os mostradores (componentes visuais). São realizadas as verificações da distância entre a aeronave e o computador da Estação Base e o nível de combustível (citadas no DFD 2.3 e 2.6.). Nesta função também é executada a função Reportar as Falhas dos Sensores (DFD 2.7).

\section{Obieto Obiect Log}

Este objeto grava e lê toda a telemetria recebida pelo STT - MB. Criado a partir da classe Trec_log, as suas propriedades são: 
- Intruments: Estrutura de dados que contém os sensores;

- Path_name_log: Path onde está ou será gravado o arquivo de log;

- Total_Record: Número de registros gravados durante uma sessão de vôo;

- Eof: Indica fim do arquivo de log.

Os métodos deste objeto são:

- Initialize: Configura os parâmetros do objeto Log;

- StartLog: Inicia o processo de gravação da telemetria recebida. Este procedimento é realizado quando o canal do modem é aberto;

- Record_Log: Grava a telemetria recebida. Sua entrada é o próprio objeto Instruments;

- StopLog: Encerra o processo de gravação da telemetria. Este método é equivalente a um close em um arquivo do sistema;

- Bottom: Posiciona o handler no final do arquivo de log;

- Top: Posiciona o handler no top do arquivo de log;

- Next: Busca o próximo registro do arquivo de log;

- Previous: Busca o registro anterior do arquivo de log;

- Record_current: Informa o número do corrente registro do arquivo de log;

- OpenLog: Abre ou Cria um novo arquivo de log.

Este objeto permite manipular o arquivo de $\log$ como se fosse um banco de dados. Como descrito no requisito funcional, o mesmo foi gravado de forma binária e para economizar espaço, foi realizado um casting nos tipos de dados dos sensores.

\section{Objeto Object statistics}

O objeto Object_statistics realiza cálculos estatísticos para se obter o menor, maior e a média dos valores mostrados em alguns instrumentos. Criado a partir da classe Trec_Statistics, a sua entrada $e$ o objeto de log.

Os seus métodos são:

- Initialize: Configura as variáveis de controle de objeto;

-Update_Statistics: Atualiza o objeto com os dados do Object_log.

Quando o operador solicita ao sistema para verificar o arquivo de log gerado, o 
mesmo é aberto através do Object_log e em seguida são carregados todos os registros para o objeto grid da tela. Durante este processo, o objeto de estatística recebe como parâmetro os dados do objeto de log e os cálculos são processados.

\subsubsection{Arquitetura de Implementação do STT - MA}

A fase III do Projeto ARARA fornece os elementos básicos para as fases mais avançadas do projeto. Para construir o STT - MA, também foi adotada a mesma estrutura em três camadas utilizada para a implementação do STT - MB.

Na Camada Kernel (figura 5.3), reside o sistema operacional onde são realizadas as operações com o kernel do Linux e as leituras dos sensores. A Camada Validação (intermediaria), é responsável por disponibilizar os dados obtidos pelos sensores e formatá-los no padrão especificado na seção 2.4.5. Nesta camada, são criados os threads que formatam os dados e realizam a comunicação com o modem a bordo da aeronave. Finalmente, na Camada de Controle, reside o software de controle de navegação que será implementado na fase III do Projeto ARARA.

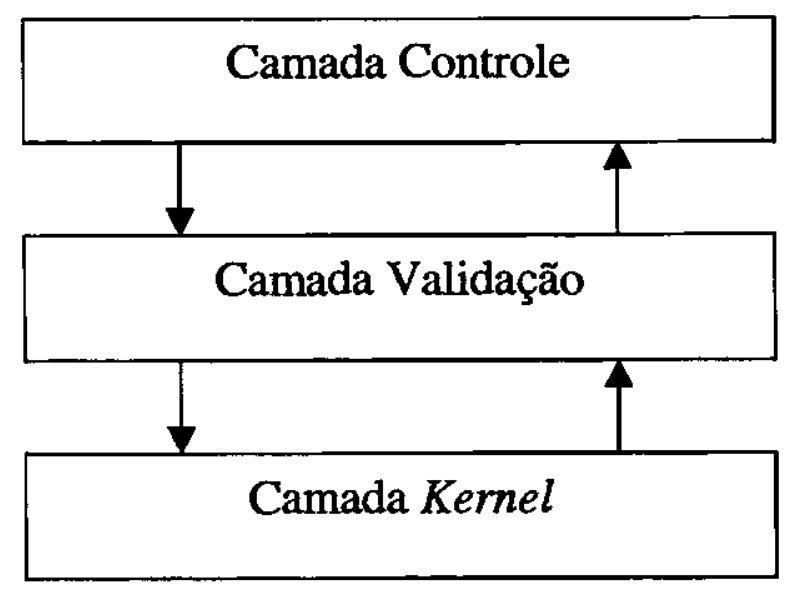

Figura 5.3 Modelo de implementação do STT - MA.

A opção pelo uso de threads ao invés de forks se deve ao menor custo computacional dos primeiros. O modelo de memória compartilhada permite dispensar o uso de IPC (Inter Process Communication) e outros mecanismos para comunicação entre processos [TAN92]. A estrutura que contém os dados dos sensores foi compartilhada para que outros threads, como o controle de vôo, tenham acesso aos dados. A figura 5.4 mostra a disposição dos threads no módulo aéreo. Cada bloco pode representar mais de um thread. 
O bloco Coleta de Dados foi implementado utilizando-se dois threads. O primeiro, Read_Sensor, é responsável por realizar a comunicação com a rede $I^{2} \mathrm{C}$. A comunicação com a rede $\mathrm{I}^{2} \mathrm{C}$ é feita através da porta paralela utilizando módulos para o Linux. Estes módulos estão incorporados no kernel a partir da versão 2.3 [12C00]. O thread lê os dados de /dev/i2c0 e coloca os dados em uma tabela temporária chamada Table_Sensor. Todas as vezes que algum dado é colocado na tabela o número de vezes que aquele sensor foi atualizado é incrementado.

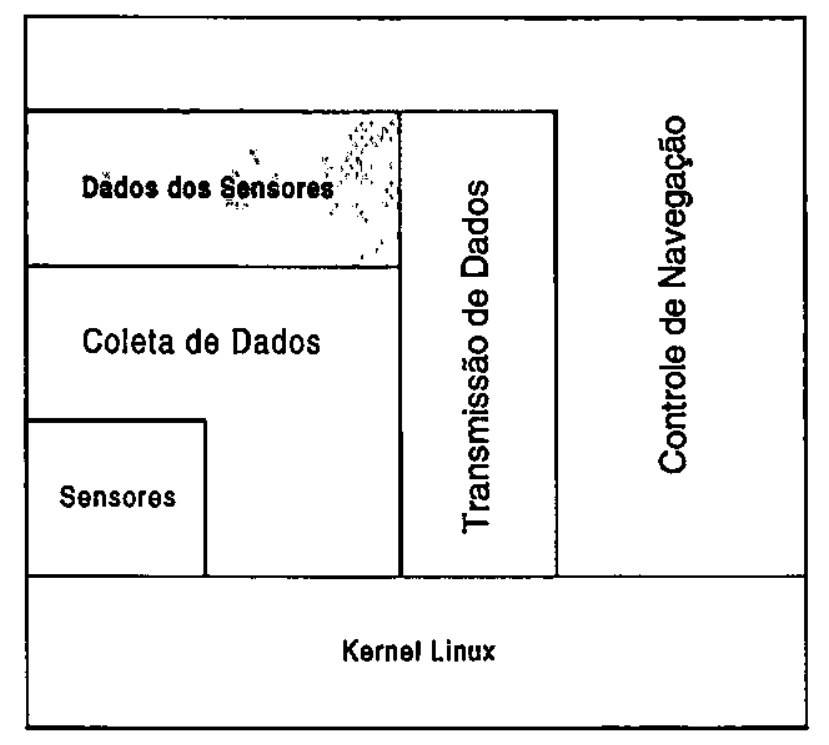

Figura 5.4 Diagrama da organização dos threads no módulo aéreo.

O segundo thread, implementado com o nome de Make_Data_Sensor, é responsável pela formatação dos dados no padrão especificado na seção 2.4 .5 e pela verificação de qual campo da Table_Sensor não foi atualizado. O thread Read_Sensor mantêm uma estrutura pública compartilhada por outros threads chamada Sensor_Data, representada no diagrama pelo bloco Dados dos Sensores. A Sensor_Data é atualizada em intervalos de 0.2s. As estruturas Table_Sensor e Sensor_Data são criadas a partir do tipo de dados TInstruments.

Antes de executar os threads, o sistema configura a Table_Sensor e a Sensor_Data com os valores correspondentes a falhas. Cada item da tabela é declarado com o tipo Tint que é definido da seguinte maneira:

struct Tint \{ float timestamp; / Quantas vezes o sensor foi atualizado;

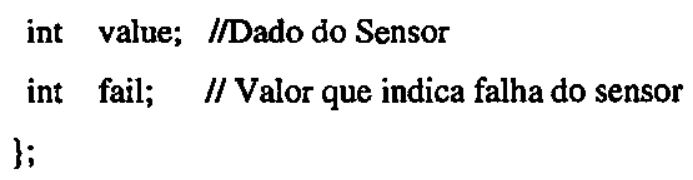


Os dois threads são criados imediatamente após a iniciação do sistema. Entretanto, o thread Make_Data_Sensor aguarda 0.5 segundo para que o thread Read_Sensor tenha tempo de ler os dados dos sensores. Este tempo é necessário para acomodar o mecanismo de reconhecimento de falha dos sensores. Quando o segundo thread é executado o último time_stamp de leitura marcado na Table_Sensor é comparado com o valor do time_stamp marcado na estrutura Sensor_Data. Se os dois threads forem iniciados simultaneamente, o thread Make_Data_Sensor iniciará o dado do sensor com o valor corresponde à falha, por exemplo, -1 .

O bloco Transmissão de Dados foi implementado como um thread com o nome de Transmitter_Data. Este thread lê a estrutura Sensor_Data e a transmite para o computador da Estação Base. O bloco Controle de Navegação foi apresentado no diagrama para mostrar o compartilhamento da estrutura Sensor_Data.

Para controlar o acesso à estrutura Sensor_Data, foi implementada uma mutex que garante o controle de acesso à estrutura, neste caso uma região crítica. Nenhum sincronismo foi realizado nos threads, como no caso do problema do produtor-cosumidor, pois as funções que compartilham a estrutura Sensor_Data apenas realizam leitura sobre ela.

\subsection{Validação e Teste do STT}

Devido à falta de recursos financeiros para aquisição dos componentes de hardware necessários para a implementação da aeronave da fase II do Projeto ARARA, a validação do sistema foi feita através de simulações. Para simular a visualização das imagens e a comunicação entre a aeronave e o computador da Estação Base foram utilizados dois computadores.

Para fazer o papel do computador a bordo da aeronave, utilizou-se um Pentium 120 MHz com 32 Mbytes, 1Gbyte de disco, uma câmera de vídeo da marca Genius e um transmissor de vídeo kit ATV-2 da Supercircuits [SUP99]. O computador executa o sistema operacional Linux com o kernel 2.2.15. Para o computador da Estação Base, utilizou-se um Pentium II 400 MHz com 64 Mbytes, placa de som Sound Blaster 16 bits, placa de TV Pixel View Combo e 4 Gbytes de disco, executando o sistema operacional Windows 98-SE. A comunicação entre os computadores foi feita através das suas portas seriais utilizando-se um cabo. A figura 5.5 mostra detalhes da ligação dos computadores utilizados para o teste. 


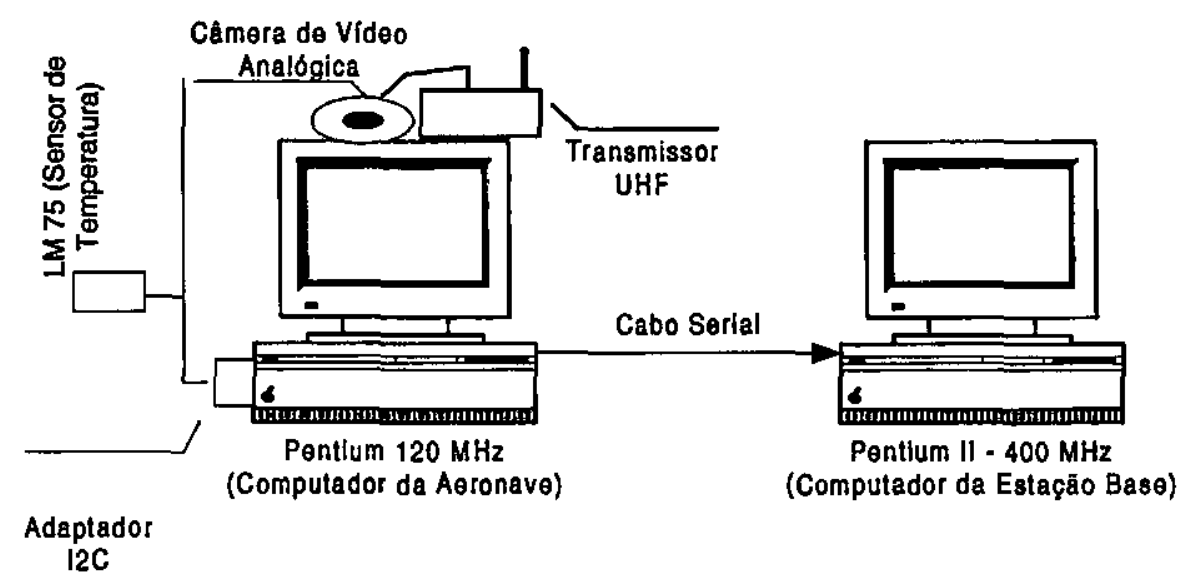

Figura 5.5 Esquema de montagem dos computadores para teste.

Foi elaborada uma lista de atividades de teste para verificar o comportamento do STT. As atividades são as seguintes:

- STT - MA é carregado no Linux;

- $\mathrm{STT}$ - MB é carregado no Windows;

- STT - MB é desligado por falta de energia no computador da Estação Base ou por erro do Windows;

- O operador abre o canal do modem no STT - MB;

- O operador fecha o canal do modem do STT - MB durante o vôo;

- Os dados transmitidos pelo STT - MA contém o caractere de controle;

- Funcionamento do STT após 24 horas ininterruptas sem a gravação do arquivo de $\log$;

- Os sensores a bordo da aeronave não respondem ou informam valores inesperados;

- O operador executa outro programa durante a execução do STT - MB;

- O STT - MB é executado sobre o sistema operacional Windows 95, 98, 98-SE, 2000 ;

- O STT - MA recebe um dado do sensor fora das especificaçðes.

O processo de leitura dos sensores foi simulado por um Stub que gera números 
aleatórios. O mecanismo de coleta foi implementado. Abaixo são apresentadas as respostas do sistema a cada evento citado acima.

\section{STT - MA é carregado no Linux}

Neste item, procurou-se avaliar a resposta do sistema quando o mesmo é iniciado. $O$ STT - MA iniciou os threads e imediatamente começou a transmitir os dados para a porta serial. O teste foi avaliado em duas situações: a primeira sem o STT - MB e a segunda com o mesmo em operação. Tanto na primeira como na segunda situação, o STT - MA iniciou a transmissão dos dados para o STT - MB sem problemas.

\section{STT - MB é carregado no Windows}

O STT - MB foi iniciado normalmente sem nenhuma erro. O painel de visualização das imagens iniciou juntamente com o painel dos instrumentos.

STT - MB é desligado por falta de energia no computador da Estacão Base ou por erro do Windows

Neste evento procurou-se avaliar se o sistema tinha condições de ser reiniciado. O STT - MB foi desligado e reiniciado várias vezes. Nenhum arquivo do sistema STT - MB foi corrompido. Este teste é subjetivo uma vez que não se tem controle sobre as operações de arquivo que o Windows faz, como por exemplo, os arquivos de swap do mesmo. Um detalhe previsto é a geração de um novo arquivo de log toda vez que o programa é executado.

\section{O operador abre o canal do modem no STT - MB}

Quando o operador aciona a chave Open Modem, o STT - MB solicita o nome do arquivo de $\log$ e a localização do computador da Estação Base (latitude, longitude e altitude). $\mathrm{O}$ STT - MB consegue reconhecer o pacote de dados sempre que o canal do modem é aberto. Se a aeronave não transmite nenhum pacote, os indicadores dos instrumentos permanecem na última posição marcada. 


\section{O operador fecha o canal do modem no STT - MB durante o vôo}

O canal do modem foi aberto e fechado várias vezes. O sistema efetuou o reconhecimento dos pacotes sem erros, validando a não necessidade de sincronismo entre a computador da Estação Base e o computador da aeronave.

\section{Os dados transmitidos pelo STT - MA contém o caractere de controle}

Uma massa de dados foi gerada contendo vários caracteres de controle no meio do pacote. Várias combinações foram testadas para avaliar esta situação. Os caracteres de controle foram inseridos nas seguintes posições: no inicio, meio e fim do pacote. Também foi testado inserido o caractere de controle 3 a 4 vezes consecutivas, no mesmo pacote.

\section{Funcionamento do STT após 24 horas ininterruptas sem a geracão do arquivo de}

$\underline{\log }$

O sistema não apresentou nenhuma falha durante 24 horas contínuas de funcionamento. $O$ teste foi gerado sem o arquivo de $\log$ por limitação de espaço de armazenamento no disco rígido.

Os sensores a bordo da aeronave não respondem ou informam valores inesperados

Quando um sensor falha a bordo da aeronave, o STT - MB automaticamente acende o led de falha dos sensores. Uma falha pode ocorrer quando o sensor não está respondendo ou está informando valores fora do padrão especificado nos requisitos funcionais dos sensores. Para simular a falha dos sensores, foi bloqueado o thread que realiza a leitura dos sensores. Na simulação, o STT - MA reconheceu que os sensores não estavam respondendo, indicando ao STT - MB que estes falharam.

Para simular uma resposta errada dos sensores, os dados de entrada dos sensores foram informados via teclado no computador da aeronave. O STT - MA detectou as falhas nas respostas dos sensores e as transmitiu ao STT - MB.

\section{O operador executa outro programa durante a execucão do STT - MB}

Quando um protetor de tela é ativado nenhuma avaria foi detectada no sistema. 
Entretanto, problemas podem ocorrer quando é ativado algum programa que faça acesso ao dispositivo de captura de vídeo. O STT - MB, nesses casos, ficou sem acesso a esse dispositivo.

O STT - MB é executado sobre o sistema operacional Windows 95, 98, 98-SE, $\underline{2000}$

O STT - MB pode ser executado no Windows 95 e 98 sem nenhuma modificação. Entretanto, para o Windows 98-SE é necessário selecionar em Multimídia $\Rightarrow$ Dispositivos $\Rightarrow$ Vídeo Captura $\Rightarrow$ TVTap VidCap Driver. Para o windows 2000, não foi possível executar o sistema pela não disponibilidade de um driver de captura de vídeo para a placa Pixel View Combo, chipset 5460 da Cirrus Logic.

\subsection{Interfaces do Sistema}

Nesta seção, são mostradas as telas de interface do STT - MB. A figura 5.6 mostra o diagrama de transição de estados das interfaces de tela de vídeo. Todos os comandos são acionados a partir da tela do painel de instrumentação. O STT - MA não possui nenhuma interface de tela.

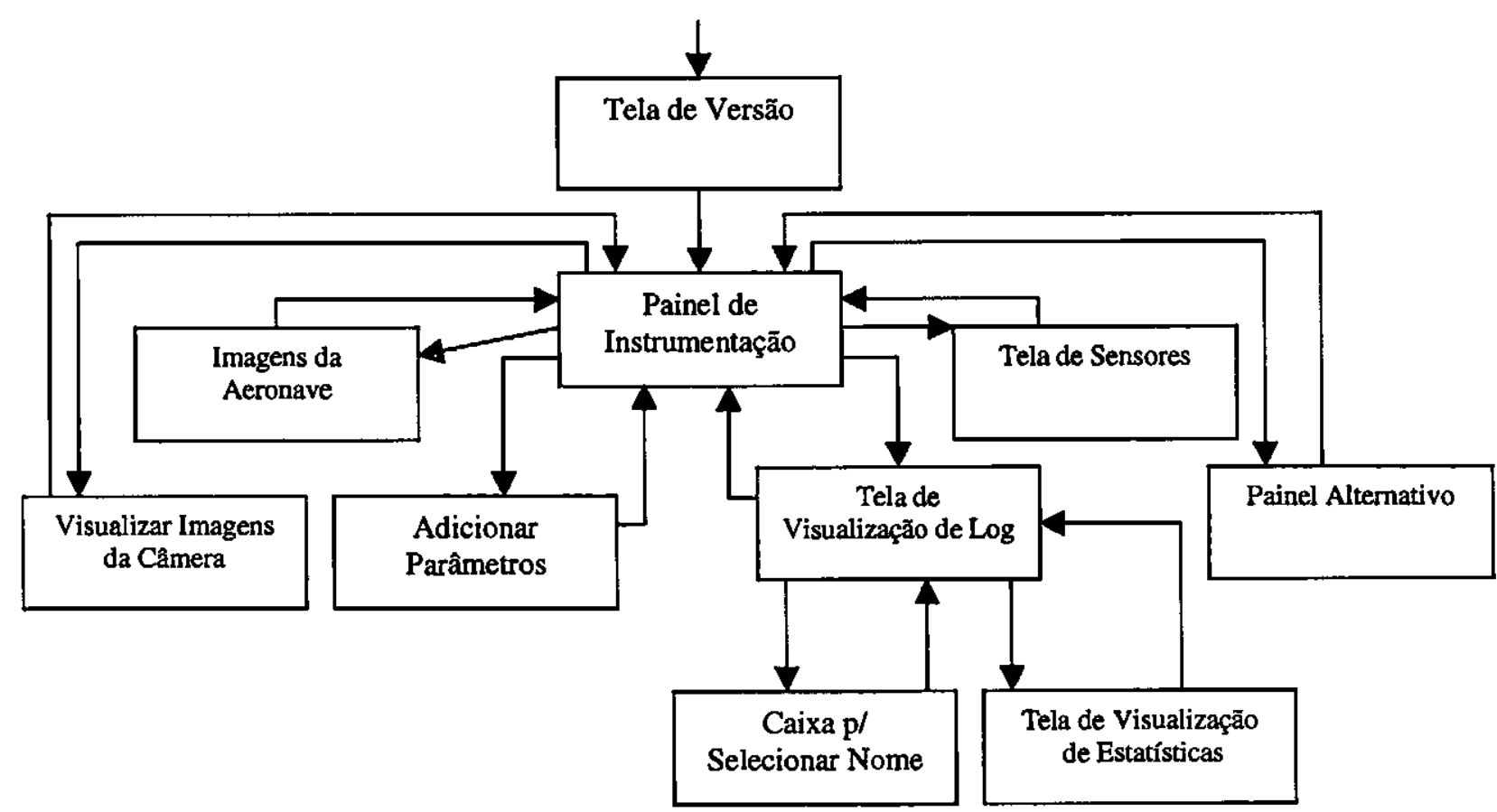

Figura 5.6 Diagrama de transição de estado das interfaces de tela de vídeo. 
Na figura 5.7, é mostrado o painel de instrumentos do STT - MB de acordo com os requisitos funcionais apresentados na seção 3.4.1.

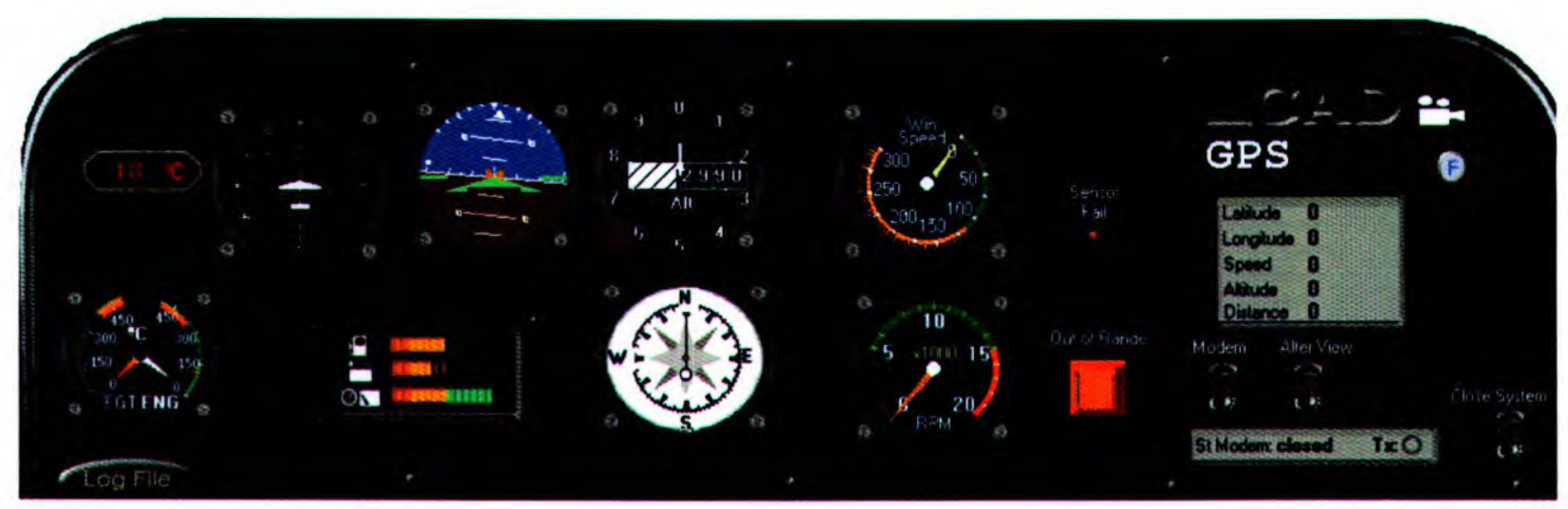

Figura 5.7 Painel de instrumentos do STT.

Sempre que a aeronave estiver próxima de sair do perímetro de alcance, previamente configurado no sistema, o sinalizador Out of Range começa a piscar. Ele somente é desativado quando a aeronave estiver dentro de um perímetro seguro para vôo.

Durante um vôo pode ocorrer a falha de algum sensor. Caso isto ocorra, o led Sensor Fail começa a piscar. Para visualizar qual sensor não está respondendo, basta "clicar" sobre o led, e é aberto um painel mostrando qual sensor está falhando. A figura 5.8 mostra detalhes deste painel. A seta para baixo esconde novamente o painel. O operador pode optar pela apresentação contínua deste painel.

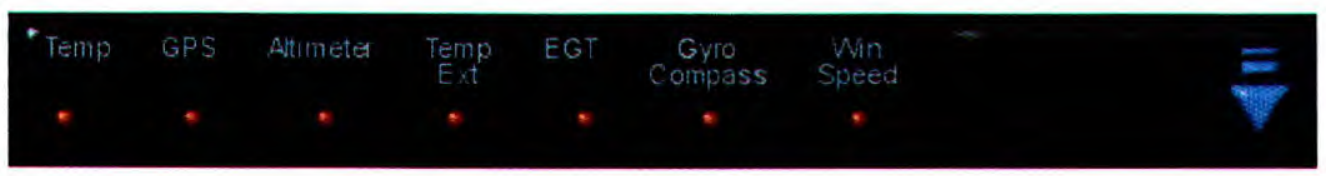

Figura 5.8 Painel de falha dos sensores.

A figura 5.9 mostra a tela de diálogo que é visualizada quando o operador abre o canal do modem. É solicitado o nome do arquivo de $\log$ da telemetria e as coordenadas de localização (latitude,longitude e altitude) do computador da Estação Base. 


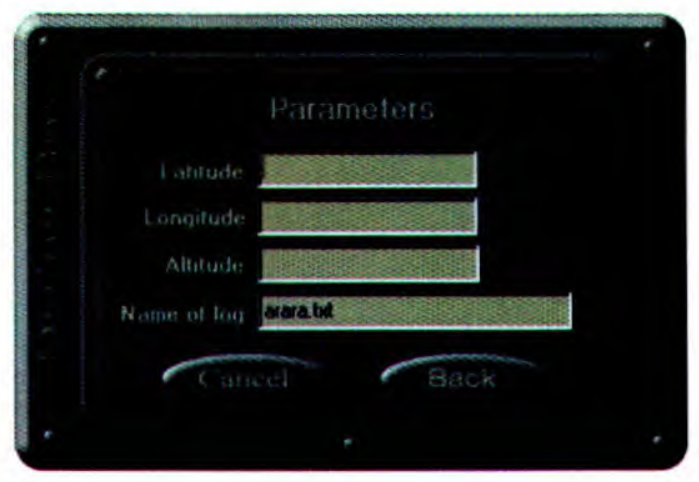

Figura 5.9 Tela de Diálogo para gravar o nome do arquivo de log.

A figura 5.10 mostra a tela do $\log$ da telemetria. Para carregar o arquivo, o operador deve pressionar o botão load, e inserir o nome do arquivo em uma caixa de diálogo. Após isso, o sistema carrega o arquivo e mostra os dados no browser.

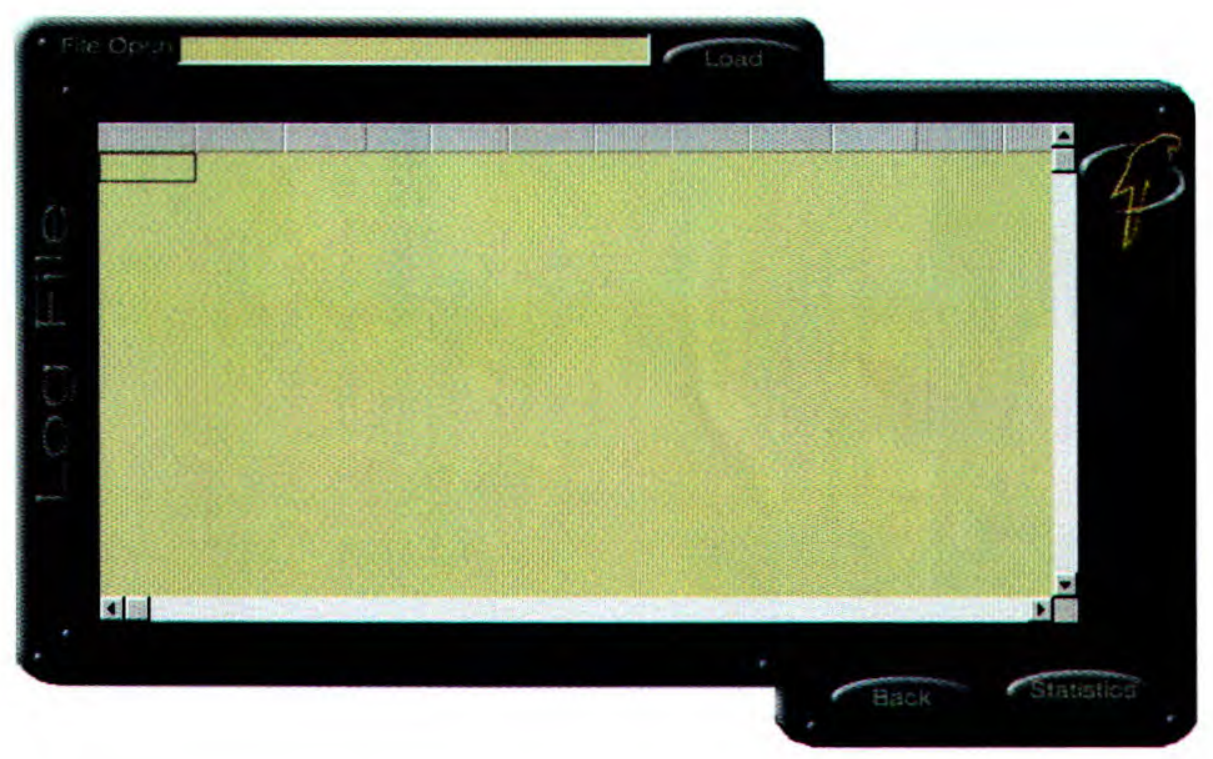

Figura 5.10 Tela do $\log$ da telemetria.

O operador pode escolher a opção de voltar (botão back) ou visualizar a estatística dos instrumentos. O botão statistics somente está disponível quando o arquivo de log é carregado.

A figura 5.11 mostra a tela de estatística do arquivo de $\log$. Nesta tela são mostrados os níveis mínimos, máximos e as médias aritméticas dos valores de cada sensor. 


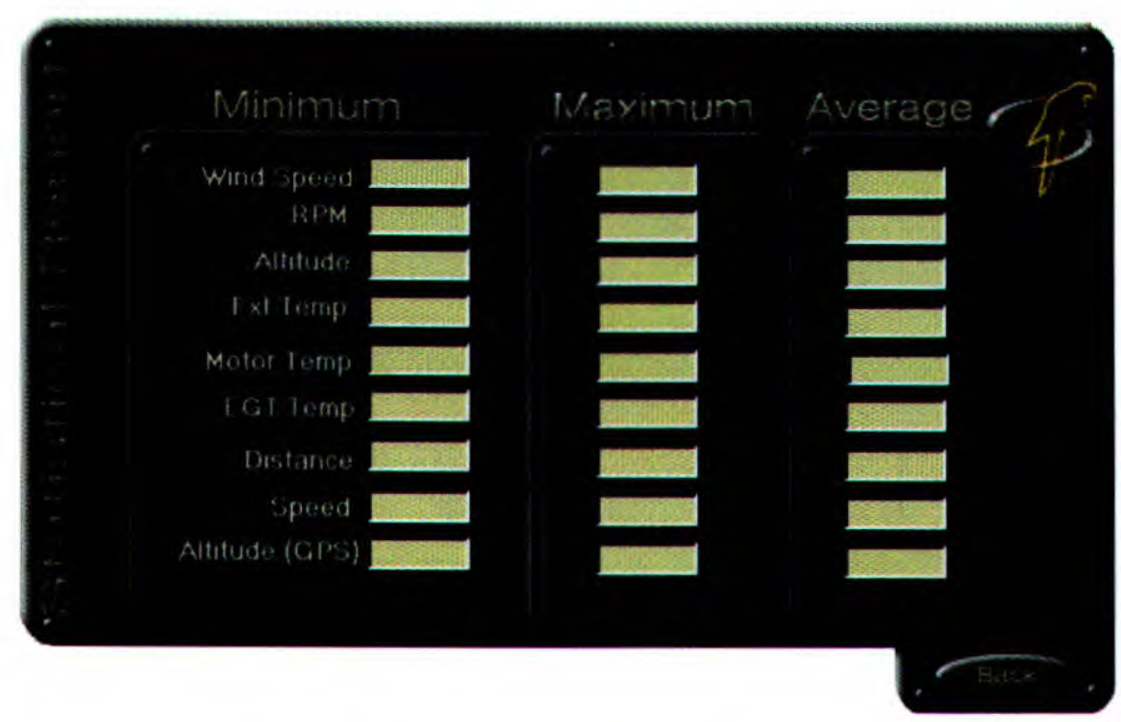

Figura 5.11 Tela de estatística dos sensores.

A figura 5.12 mostra o formulário que permite o operador visualizar as fotos obtidas com a câmera fotográfica. Para abrir uma foto, basta selecionar o nome do arquivo na caixa de nomes com um click do mouse.

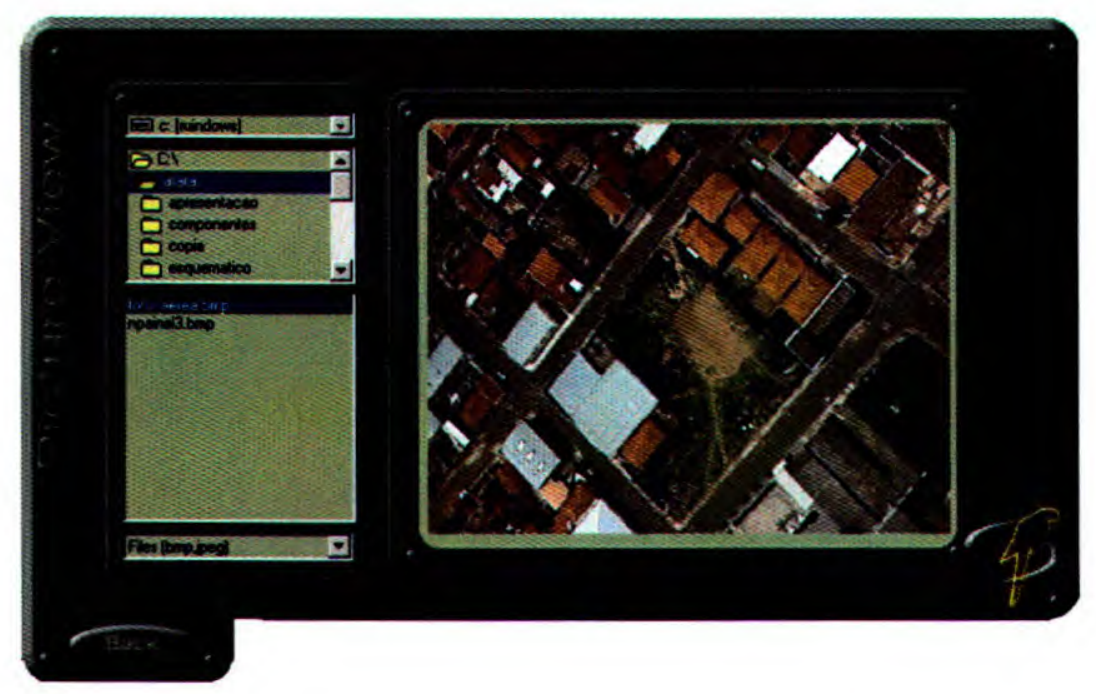

Figura 5.12 Tela que visualiza as imagens BMP e JPEG.

\subsection{Considerações Finais}

O projeto e a implementação de software do Projeto ARARA na fase II foram apresentados nesse capítulo. Também foram detalhados quais sensores foram utilizados na fase II e foram apresentadas as estratégias de implementação do STT - MA e MB. O STT - MB foi construído utilizando componentes OCX, também conhecidos como ActiveX, compatíveis com 
o navegador da Microsoft (Internet Explorer). Isto permitirá no futuro a migração do STT - MB para o navegador, caso seja desejado, com pequenas alterações.

Neste capítulo também foi descrita a bancada de testes montada para avaliar o STT. Foi gerada uma lista de situações que devem ocorrer durante o seu uso. Também foram apresentadas as telas do sistema e uma rápida descrição do seu funcionamento.

No próximo capítulo são apresentadas as conclusões deste trabalho e as sugestões para trabalhos futuros. 


\section{Capítulo 6}

Conclusões

\subsection{Considerações Iniciais}

Neste trabalho, foi apresentada uma revisão bibliografica cobrindo a definição de UAVs, os tipos de UAVs, os equipamentos que compõem os UAVs e as aplicações onde os UAVs podem atuar. O mercado para sistemas com UAVs deve crescer bastante nos próximos anos principalmente em aplicações civis.

Foram definidos o projeto ARARA e as suas fases. Dentre as quatro fases definidas, a fase I foi implementada por Souza em seu trabalho de mestrado. Uma análise de requisitos de hardware e software foi realizada para a fase II, resultando na especificação do STT - Sistema de Telemetria e Telecomando do Projeto ARARA.

Também foram apresentados detalhes da implementação do STT e os testes de validação do sistema.

Neste capítulo, são enumeradas, na seção 6.2, as contribuições deste trabalho e na seção 6.3, as sugestões para a sua continuidade.

\subsection{Contribuições do Trabalho}

O desenvolvimento deste trabalho resultou nas seguintes contribuições mais significativas:

- Definição do Projeto ARARA e as suas quatro fases de desenvolvimento, com 
níveis progressivos de aplicabilidade;

- Desenvolvimento de um módulo de coleta de dados dos sensores a bordo da aeronave, tornando os dados dos sensores disponíveis em uma estrutura de dados. Este módulo permite o desenvolvimento de outros módulos do projeto, em particular, o do piloto automático;

- Desenvolvimento de uma interface para possibilitar o vôo remotamente pilotado e sem visada direta de aeronaves do Projeto ARARA. O piloto em terra pode, com o uso dessa interface, acompanhar as imagens e os dados coletados pelos sensores embarcados na aeronave;

- Desenvolvimento de um módulo para armazenamento de toda a telemetria do sistema durante o vôo. Estes dados permitirão o desenvolvimento de um simulador para a análise do vôo da aeronave.

- Implementação do protocolo de transmissão de dados de telemetria via rádio especificado por Souza [SOU99].

\subsection{Sugestões para Trabalhos Futuros e Continuidade da Pesquisa}

Conforme descrito no capítulo 3, foram definidas quatro fases de desenvolvimento para o Projeto ARARA. Neste trabalho foi implementado o software STT, necessário na implementação da fase II. As fases III e IV podem ser desenvolvidas em paralelo, aproveitandose a experiência obtida com a realização deste trabalho e o de Souza [SOU99]. A seguir, relaciona-se uma série de projetos que dão continuidade ao trabalho até aqui desenvolvido. $O$ nível desses trabalhos, na maioria dos casos, é adequado para um programa de mestrado.

- Implementação de um sistema para transmissão digital de vídeo e dados. Este sistema deve permitir a comunicação bidirecional para que seja possível interferir na configuração dos equipamentos a bordo da aeronave;

- Implementação de um painel de instrumentos totalmente digital, onde os mostradores são apresentados em modo de overlay combinados com a imagem na tela, semelhante ao que é encontrado nos aviões de combate mais recentes; 
- Implementação do controle da aeronave utilizando controladores de joystick,

- Desenvolvimento do controle de missão de vôo para a fase Mim;

- Desenvolvimento de uma interface 3D para visualizar o log de telemetria, onde o operador poderá acompanhar a trajetória feita pela aeronave, bem como verificar onde ocorreu em cada tarefa executada. Na interface, o operador poderá, por exemplo, verificar em qual ponto foi tirada uma determinada fotografia ou exibir um trecho que foi filmado durante a missão;

- Desenvolvimento de uma interface para facilitar a inserção de novos sensores. A configuração do protocolo para incluir um novo sensor pode ser do tipo drag-drop, semelhante a encontrada no IDE (Interface Development Environment) do Dephi 4.0. A interface deverá permitir que o operador crie o seu instrumento de acordo com o sensor, adaptando o sistema para qualquer tipo de missão;

- Desenvolvimento de um módulo para atuar como uma interface entre o computador da Estação Base e o transmissor de rádio controle, permitindo vôos assessorados por computador; 


\section{Referências Bibliográficas}

[AES99] "Aerosonde"; [online]. [08/03/1999]. Disponível na Internet: <http:// www.bom.gov.au/bmrc/meso/New/Aerosonde/aero_intro.htm>

[AIR99] AIRSHIP AND BLIMP RESOURCES; "Introduction to Airship"; [online]. [19/03/1999]. Disponível na Internet: $<$ :http://www.hotairship. com/intro/index.html >

[AIR99a] AIRSHIP AND BLIMP RESOURCES; "RC Blimp Parts"; [online]. [19/03/1999]. Disponível na Internet: <http://www.hotairship. com/intro/ index.html >

[ANG99] ANGEVINE, W; HETHCOAT, G; MOHAMED, S; "Faq about $R C^{\prime \prime}$; [online]. [24/03/1999]. Disponível na Internet: $<\mathrm{http}: / /$ bigwing.geology .indina.edu/models /FAQ/rc_faq.txt $>$

[BAY99] BAYCOM; "Bavarian Packet Radio Group"; [online]. [10/03/1999]. Disponível na Internet :<http://www.baycom.org>

[BOR98] BORLAND INTERPRISE;"Econoclasts"; [online] [10/12/1998] Disponível na Internet: http://www.borland.com/delphi>

[BOR99] BORENSTEIN, J.; "The HoverBot $C$ - The Electrically Powered Flying Robot"; [online]. [01/02/1999]. Disponível na Internet: <ftp: //ftp.eecs.umich.edu/people/johannb/paper99.pdfs

[CAN96] CANTÚ, MARCOS, "Dominado o delphi 2 para Window/NT" : São Paulo: MAKRON Books, 1996

[CAR99] CARNEGIE MELLON ROBOTICS INSTITUTE; "Autonomous Helicopter Project"; [online]. [03/03/1999]. Disponível na Internet http://www.sc.cmu.edu/afs/cs/project/chopper/www/goals.html>

[CHE99] CHEERS, JEREMY COULTER; "Visual Software Soultions": [online].[10/06/1999] Disponível na internet <http://www.voyager .co.nz/ jcoulter/index.htm>

[CON95] CONWAY, ANDREW R.; "Autonomous Control of an Unstable Helicopter Using Carrier Phase GPS Only" : Tese Doutorado 
Universidade Stanford CA 94305 ; Março: 1995

[WOO99] WOODLEY, B.; JONES, H.; FREW, E.; LEMASTER, E.; ROCK, S.; "A contestant in the 1997 International Aerial Robotics Competition. Aerospace Robotics Laboratory Stanford University". [online]. [01/01/1999]. Disponível na Internet: <http://sunvalley.standford.edu/projects/ helicopters/helicopters.html/info.html>

[DEL99] DELFRATE, J. H.; COSENTINO G. B.; "Recent Flight Test Experience With Uninhabited Aerial Vehicles at the NASA Dryden Flight Research Center": [online]. [19/03/1999]. Disponível na Internet: <http:// www.dfrc.nasa.gov/DTRS/1998/PDF/H-2220.pdf>

[ELF98]

[EWI99]

[EWI99a]

[FAR97]

[GLO99]

[I2C00]

[JON99]

[JOR96]

[KAD94]

ELFES A.; BUENO, S.S; BERGERMAN, M; JOSUÉ JR, G.R; GOMES, S .B. V.; "Project AURORA: Development of the Autonomous Unmanned Remote Monitoring Robotics Airship" Journal Of The Brazilian Computer Society. V.4, p.70-78, 1998

EWING,J.; East Coast Model Center "Introduction to R/C Aircraft"; [online]. [10/03/1999]. Disponível na Internet <http://www.ecmc .com/document/ intair.htm >

EWING,J.; East Coast Model Center, "Introdution to $R / C$ Helicopters"; [online]. [05/03/1999]. Disponivel na Internet <http:/l www.ecmc.com /document /intheli.htm >

FARRAR, BRAIN, "Usando o activeX": Rio de Janeiro: Campus, 1997

GLOBAL MAJIC SOFTWARE, "Gauge for Aircraft": [online]. [08/02/1999] Disponivel na internet < http://www.globalmajic.com>

I2C BUS FOR LINUX; [online] [05/05/2000] Disponível na internet $<$ http://www.tk.uni-linz.ac.at/ simon/private/i2c/>

JONKUNU'S HELIPAD; "RC Helicopters Described"; [online]. [18/04/1999]. Disponível na Internet : <http://www.geocites.com/ CapeCanaveral/Launchpad/6739/beginners/rchd/novice100.htm>

JORGE, L.A.C; "Circular Técnica 01/96" ; EMBRAPACNPDIA : São Carlos - SP : 1996

EL KADY, M; MACK,C.B.; "Crop Inventory in Egypt Using Remote Sensing", USAID Surveying and Mapping Project : Cairo : 1994

[LET98]

[LOG92]

LETHAM, L., "GPS Made Easy”, Rocky Mountain Books, $2^{\text {a }}$ ed., Canada, 1998

LOGSDON, T., "The Navstar Global Positioning System": Van Nostrand Reinhold, New York, 1992

[MIC99] MICROSOFT;"Microsoft Simulator 98"; [online]. [01/02/1999]. Disponivel na Internet: <http://www.microsoft.com/games/fsim> 
Disponível na Internet: <http://www.microsoft.com/games/fsim>

[UNI99] UNIVERSTTY OF MICHIGAN; "UAV"; [online]. [08/03/1999]. Disponível na Internet: < http://uav .engin.umich.edu/>

[DEB97] DEBITETTO, P; "MIT/ Draper Autonomous Helicopter Project"; last update: 2 june 1997; [online]. [03/03/1999]. Disponível na Internet: <http://web.mit.edu/whall/www/heli/>

[MON99] MONTGOMERY, J.; "The University of Southern California AVATAR - Autonomous Vehicle Aerial Tracking and Retrieval"; [online]. [08/03/1999]. Disponível na Internet: <http://wwwrobotics.usc.edu/nav2.html>

[MOR99] MORITA, Y.; McKENNEY, H; "An Assessment of Technical Factors Influencing the Potential Use of RPV's For Minefield Detection." [online]. [01/01/1999]. Disponível na Internet: http://web.nps.navy.mil/ library/bibs/land20thtri_m.htm>

[MUL99] MULINUX DISTRIBUTION [online] [10/06/1999] Disponível na internet <http://www.freshmit.distribution.mulinux.>

[NOV00] NOVATEL; 'Products", [online] [20/02/2000] Disponível na internet <http://www.novatel.com/Products.html>

[ETH00] ETH - EIDGENÕSSISCHE TECHISCHE HOCHSHULE ZURICH; "ETH Oberon Home Page"; [online] [20/02/2000] Disponível na internet <http://www.oberon.ethz.ch/>

[PAL85] PALLET, E H J; "Aircraft Instrument": Principles and Applications : 2 ed. ; Longman Scientific \& Technical; England : 1985

[PRE95] PRESSMAN, ROGER S.; "Engenharia de Software". Makron Books - São Paulo, 1995

[PRO96] PROCHASKA, E.O.C; "Aprendendo a Voar - Manual Básico para Treinamento Prático de Piloto" : 3ed" atualizada ASA ; Ediçōes e Artes Gráficas Ltda. : São Paulo - SP : 1996

[REC99]

RECHARGEABLE SYSTEMS; "Competive System Matrix": [online]. [10/03/1999] Disponível na internet <http://www.cccsrv.trevano.ch/ blutz/Electronics/ElecAkkus.html.>

[RIG99] RIGID AIRSHIP DESIGN N.V.; "Frequently asked Questions" : [online]. [19/03/1999]. Disponível na Internet: <http:// members.Tripod. com/rigid /air6.htm>

[ROS99] ROSE-HULMAN INSTITUTE OF TECHNOLOGY; "Aerial Robotics Club; [online]. [07/03/1999]. Disponível na Internet: < http://www.rose-hulman.edu/Users/groups/ARC/Public/HTML/ index.html >

[RSR97] REMOTE SENSING RESEARCH; "The Sensoar RPV"; [online]. [08/03/1997]. Disponível na Internet: <http://rsr. Org.plataform. 
html>

[SH192]

[SIE99]

[SIU91]

[SOU99]

[SPA99]

SHILLER, LARRY; “Excelência em software", Makron Books, São Paulo, 1992

SIEWERT, S. ; BRADLEY, W.; "AIM UAV (Unoccupied Air Vehicle)" [online]. [09/03/1999]. Disponível na Internet:<http://www -sgc.colorado.edu/people/siewrts/testbed/ floarters.html>

SIURU, B., "Planes Without Pilots Advances in Unmanned Flight", $1^{2}$ ed., USA, TAB Books, McGraw-Hill, Inc.: 1991

SOUZA,N.P; "Uso de Aeronaves Rádio Controladas para Aplicação na Agricultura - $O$ protocolo de Enlace de Dados"; USP : publicação Dissertação de mestrado, março de 1999

SPAWAR - SYSTEM CENTER SAN DIEGO; "Airbone Remotely Operated Device". [online]. [11/02/1999]. Disponível na Intemet: http://www.nosc.mil/robots/air/arod/arod. Html>

[SUP99] SUPERCIRCUITS; "wireless vídeo": [online] [01/02/1999] Disponível na internet <http://www.supercircuits.com>

[SWI99] SWISS FEDERAL INSTITUTE OF TECHNOLOGY; "Helicopter Projects" [online]. [10/08/1999]. Disponível na Internet <http://www. imrt.mavt.ethz.ch/ heli/Heli_Page.html>

[TAN92] TANENBAUM, A.S.; "Modern Operating System", New Jersey, Prentice Hall : 1992

[TAN96] TANENBAUM, A.S.; “Computer Networks", 3.New Jersey, Prentice Hall : 1996

[THO99] THOMAS,M.L.; RALPH,W.K.; "Introduction To Remote Sensing" ; [online]. [03/03/1999]. Disponível na Internet: <http://www.star.ait. ac.th/gac/gisrs.html>

[TOW99] TOWERHOBBIES; "Radio: The Heart of R/C Modeling". [online]. [24/03/1999]. Disponível na Internet: < http://www. towerhobbies.com/ introradio.html>

[TOW99a] TOWERHOBBIES; “Radio: The Heart of R/C Modeling"; [online]. [24/03/1999]. Disponível na Internet: $:<$ http://www.towerhobbies. $\mathrm{com} /$ introradio.html>

[VID98] VÍDEO LAB; "Video Object Show"; [online] [10/06/1998] Disponível na internet <http://www.objectshow.com>

[WAR85] WARD, P.T. e S.J. MELLOR: "Structured Development for RealTime System", Yourdon Press, 1985

[WHA99] "What are Micro Aerial Vehicles?"; [online]. [11/02/1999]. Disponível na Internet: <http://www.aero.ufl.edu/ issmo/mav 
/info.htm>

[WIL98] WILSON, D.R;"Aerial Photography - University of Cambrigde "; [online]. [02/09/1998] Disponível na Internet <http://www.cam. ac.uk/CambUniv/ILRes/PhysSci/Aerial.html>

[WON99] WONG, K,; "Aerospace Industry Opportunities in Australia UNMANNED AERIAL VEHICLES (UAV's) - Are they ready this time? Are we? ". [online]. [03/03/1999]. Disponível na Internet: < http://www.aero.usyd.edu.au/wwwdocs /uav.html>

[WON99a] WONG, K, C; BIL, C. "UAV's Over Australia - Market and Opportunities". [online]. [03/03/1999]. Disponível na Internet: < http://www.aero.usyd.edu.au /wwwdocs /uav.html>

[WON99b] WONG, K, C; BIL, C. "Wav Brumby"; [online]. [08/02/1999]. Disponível na Internet: < http://www.aero.usyd.edu.au/wwwuav hav_brumby_intro.html> 


\section{Apêndice A}

\section{Dicionário de Dados}

Alt

Altitude

Altitude GPS

Altitude GPS máxima

Altitude GPS média
= Sinônimo de altitude

= Indica a altitude da aeronave em relação ao nível do mar Tipo: Inteiro de 16 bits

Representação: Intervalo [-5000 a 5000]

Valor Padrão: -9999

** A variável pode assumir o valor -9999 para indicar falha do sensor

= Indica a altura da aeronave em relação ao solo. Esta informação é enviada pelo GPS da aeronave

Tipo: Inteiro de 32 bits

Representação: Intervalo [-5E5 a 5E5]

Valor Padrão: -999999999

** O valor -999999999 indica falha do GPS

= Máxima altitude registrada pelo GPS. O tipo dessa variável é igual à Altitude GPS

= Média aritmética das altitudes registradas pelo GPS. O tipo dessa variável é igual à Altitude GPS 
Altitude GPS mínima = Mínima altitude registrada pelo GPS. $O$ tipo dessa variável é igual à Altitude GPS

Altitude máxima

Altitude média

Altitude mínima

Artificial_horizon

= Maior altitude registrada pelo altímetro. O tipo da variável é igual à Altitude

= Média aritmética das altitudes registra pelo altímetro. $O$ tipo da variável é igual à Altitude

= Menor altitude registrada pelo altímetro. $O$ tipo da variável é igual à Altitude

= Estrutura de dados que contém dados sobre a posição da aeronave no espaço

Tipo: Thoriz_artificial

**Thoriz_artificial está definido no DD

Bateria da instrumentação = Indica o nível de carga dos instrumentos a bordo da aeronave Tipo: Inteiro de 8 bits

Representação: Intervalo [0 a 100]

Valor Padrão: -1

** O valor -1 indica falha do sensor

Bateria do servos

= Indica o nível de carga do equipamento de rádio controle

Tipo: Inteiro de 8 bits

Representação: Intervalo [0 a 100]

Valor Padrão: -1

** $O$ valor -1 indica falha do sensor

Bloco para validação = Depósito de dados onde são armazenados os bytes que foram lidos do modem e que não foram validados.

Tipo: array [0..255] de caractere

Valor Padrão: \#00 
Caminho de instalação = Caminho onde está instalado o sistema

Tipo: arrary[0..255] de caractere

Valor Padrão: \#00

Charge

= Estrutura de dados que indica a carga de bateria

Tipo: Tcharge

** Tcharge está definido no DD

Check-sum do pacote = Dado que corresponde ao check-sum do pacote

Tipo: Inteiro de 16 bits

Representação: Contínua

Código do sensor

= Número que classifica o sensor

Tipo: Byte

Representação: Contínua

Comb_bordo

= Sinônimo de Bateria da instrumentação

Conjunto de mostradores = Sensor de presença de falha + Bússola + Painel de GPS + Botão de distância + Mostrador de temperatura local + Mostrador de temperatura dos gases do escapamento + Mostrador da temperatura do motor + Bússola giroscópica + Mostrador de combustível + Mostrador de bateria do sistema + Mostrador de bateria da Instrumentação + Chave de vídeo + Chave de modem + Chave de seleção de câmera + Mostrador do status do modem

Correção altitude

$=$ Dado utilizado para compensar a altitude ao nível do mar. Tipo: Inteiro

Representação: Contínua

Dado enviado pelo sensor $=$ Dados sensores não formatados 
Dados coletados

Dados da configuração

= Dados transmitidos para modem da aeronave, porém, sem o header $\mathrm{e}$ o check-sum.

$=$ Caminho de instalação + Drive de instalação + Nome do arquivo de Log + Capacidade do tanque + Perímetro de alcance

Dados de configuração dos = Sinônimo de Correção altitude sensores

Dados do log = Igual ao fluxo de dados recebidos do modem da Estação Base, porém sem o header e chek-sum.

Dados do modem = Conjunto de caracteres lidos do modem. Tipo: Caractere

Representação: Contínua

Dados dos sensores = Dados dos sensores

disponíveis

Dados dos sensores não $=$ Código do sensor + Parte da informação + Valor do sensor formatados 
Dados estatísticos da telemetria

Dados recebidos do modem da base

Dados transmitidos para modem da aeronave

Direção

Distância máxima
$=$ \{Velocidade do vento mínima + Velocidade do vento máxima + Velocidade do vento média + RPM máxima + RPM mínima + RPM média + Altitude máxima + Altitude mínima + Altitude média + Temperatura externa máxima + Temperatura externa mínima + Temperatura média + Temperatura do motor máxima + Temperatura do motor mínima + Temperatura do motor média + Temperatura dos gases do escapamento mínima + Temperatura dos gases do escapamento máxima + Temperatura dos gases do escapamento média + Distância múnima + Distância máxima + Distância média + Velocidade máxima + Velocidade mínima + Velocidade média + Altitude GPS máxima + Altitude GPS mínima + Altitude GPS média\}

= Sinônimo de Dados transmitidos para modem da aeronave

= Pacote de dados contendo os seguintes campos:

\{Header + Nível de combustível + Rotação do motor +Temperatura dos gases do escapamento + Temperatura local + Velocidade do vento + Altitude + Direção + Arfagem + Rolamento + Bateria da instrumentação + Bateria dos servos + Velocidade + Latitude + Longitude + Altitude + Tempo + Check-Sum \}

Esta estrutura foi especificada na seção 2.4 .5

= Indica o norte magnético da bússola

Tipo: Inteiro de 16 bits

Representação: Intervalo [-1 a 359]

** O valor -1 indica falha do sensor

= Máxima distância registrada pelo GPS. O tipo dessa variável é igual à Distância 
Distância média

Distância média

Drive de instalação

Egt

Estatística

Ext

Fuel

Handler do arquivo bmp

Handler do log

Handler do modem

Header

Imagem da câmera

fotografica
= Média aritmética das distâncias fornecidas pelo GPS durante o vôo. O tipo dessa variável é igual à Distância

= Média das distâncias registradas pelo GPS durante o vôo. $\mathrm{O}$ tipo dessa variável é igual à Distância

$=$ Drive onde está instalado o sistema

= Sinônimo de temperatura dos gases do escapamento

$=$ Dados estatísticos

= Sinônimo de Temperatura externa

= Sinônimo de Nível de combustível

= Handler que contém a figura a ser editada

Tipo: array de byte;

Representação: Contínua

= Ponteiro de arquivo para acessar o arquivo de log. A estrutura do arquivo é igual a estrutura Dados dos sensores.

= Ponteiro de arquivo para acessar a porta serial.

= Código que identifica o início de um quadro

Tipo: Inteiro de 16 bits

Representação: Discreta

Valor Padrão: 01111110

$=$ Arquivos de extensões .bmp ou .jpeg 
Lat

Latitude

Latitude GPS

Lista dos arquivos

disponíveis

Lista dos sensores que

falharam

$\log$

Longitude
= Sinônimo de latitude

= Dado referente à posição da Estação Base obtido por GPS Tipo: Inteiro de 32 bits

Representação: Intervalo [-6,48E8 a 6,48E8]

Valor Padrão: 00

= Indica a latitude da aeronave. Esta informação é enviada pelo GPS a bordo da aeronave. Ela é formatada em Graus, minutos e segundos.

Tipo: Inteiro de 32 bits

Representação: Intervalo [-6,48E8 a 6,48E8]

Valor Padrão: -999999999

** O valor -999999999 indica falha do GPS

$=\{$ Nome do arquivo $[\mathrm{bmp} \mid \mathrm{jpeg}]+$ Extensão + Tamanho $\}$

$=$ Tabela de Sensores

** Este fluxo recebeu este nome por que a função consulta a tabela de sensores e checa seus valores. Se o sensor estiver com o valor padrão, então o sensor não respondeu durante o período de leitura.

= Sinônimo de Dados do log

= Dado referente à posição da Estação Base obtido por GPS a bordo da aeronave

Tipo: Inteiro de 32 bits

Representação: Intervalo [-3,24E8 a 3,24E8]

Valor Padrão: 00 
Longitude GPS

Maior valor do sensor

Média aritmética dos sensores

Menor valor do sensor

Menor valor do sensor

Modem da aeronave

Modem da base
$=$ Indica a longitude da aeronave. Esta informação é enviada pelo GPS a bordo da aeronave. Ela é formatada em graus, minutos e segundos. Tipo: Inteiro de 32 bits

Representação: Intervalo [-3,24E8 a 3,24E8]

Valor Padrão: -999999999

** O valor -999999999 indica falha do GPS

= Fluxo de dados que transporta o maior valor de cada item da estrutura de dados \{Dados estatísticos\}

Tipo: Inteiro de 16 bits

Representação: Contínua

Valor padrão: 0

= Fluxo de dados que transporta a média aritmética de cada item da estrutura de dados [Dados estatísticos\}

Tipo: Inteiro de 16 bits

Representação: Contínua

Valor padrão: 0

$=\{$ Velocidade do vento mínima + RPM mínima + Altitude mínima + Temperatura externa mínima + Temperatura do motor mínima + Temperatura dos gases do escapamento mínima + Distância mínima + Velocidade mínima + Altitude GPS mínima\}

$=$ Fluxo de dados que transporta o menor valor de cada item da estrutura de dados \{Dados estatísticos\}

Tipo: Inteiro de 16 bits

Representação: Contínua

Valor padrão: 0

= Modem que está acoplado ao computador principal da aeronave

= Modem instalado no computador da Estação Base 
= Variável que informa se o combustível está em nível crítico

combustível Tipo: Logica

Valor Padrão: Falso

Módulo aéreo

= Sistema que está sendo executado no micro principal da aeronave

Módulo base

= Sistema que está sendo executado no computador instalado no solo

Mostradores

$=$ Conjunto de mostradores

Motor

= Estrutura de dados que contém dados referentes ao motor Tipo: Tmotor ** Tmotor está definido no DD

Nível de combustível = Indica a quantidade de combustível em porcentagem Tipo: Inteiro de 8 bits Representação: Intervalo [-1 a 100] Valor Padrão: -1 ** O valor -1 representa falha do sensor

Nome do arquivo bmp ou $=$ Nome do arquivo que será aberto no painel de figuras jpeg Tipo: Caractere de 255 Valor Padrão: Vazio

$\mathrm{Nr}$ de registros lidos $\quad=\mathrm{N}^{\circ}$ de registros lidos durante o processo de leitura do arquivo de log Tipo: Inteiro de 16 bits

Representação: Contínua

Valor padrão: 0

Operador escolhe nome do $=$ Fluxo que contém o nome do arquivo de log quando o modem é arquivo de telemetria aberto. Este fluxo é atribuído a variável de ambiente Path_name_log 
Pacote lidos válidos

= Um pacote válido com 100 caracteres

** O pacote foi definido na seção 2.4 .5

Pacote para gerar check- = Igual a Pacote lidos válidos porém sem check-sum sum

Pacote para transmissão = Conjunto de caractere que corresponde ao pacote de dados definido com caracteres de controle na seção 2.4.5

Tipo: Array [1..100] de caractere

** conjunto já incluso o check-sum

Pacote pronto $\quad=$ Depósito de dados que contém um quadro validado, mas que ainda não foi desempacotado.

Tipo: Array[0..32625] de caractere

Valor Padrão: Vazio

Painel = Sinônimo de Conjunto de mostradores

Painel de GPS = Latitude GPS + Longitude GPS + Velocidade + Tempo + Distância + Altitude GPS

Parâmetros para o modem $=$ Parâmetros para serem enviados para a porta serial Tipo: Array [0..255] de Caractere

Valor padrão: " $2400 / \mathrm{n} / 8 / 1$ "

Parte da Informação

= Código que identifica em quantos pedaços a informação foi divida. Tipo: Inteiro 8 bits

Representação: [1121314]

Path_name_log

= Variável que contém o nome do arquivo de log Tipo: Array [0..255] de Caractere

Valor Padrão: “ARARA.LOG” 
Perímetro de alcance

Pitch

Posição da estação base

Qt_mínima_combustível

Receptor de TV

Resposta do sensor

Rolamento

Roll

Rotação do motor

RPM
= Distância máxima que a aeronave pode estar da Estação Base

= Sinônimo de Arfagem

$=$ Latitude + Longitude + Altitude

= Variável que indica a partir de que nível a quantidade de combustível é considerada mínima.

Tipo: Inteiro de 8 bits

Representação: Intervalo [0 a 40]

Valor padrão: 10

= Placa de captura de vídeo que permite ao operador assistir TV em seu micro

$=$ Código do sensor + Valor do sensor

= Indica a rolagem da aeronave

Tipo: Inteiro de 16 bits

Representação: Intervalo [-1 a 359]

Valor Padrão: -1

** $O$ valor -1 indica falha do sensor

= Sinônimo de Rolagem

= Indica o numero de evolução por minuto do eixo do motor. Tipo: Inteiro de 16 bits

Representação: Intervalo [-1 a 20000]

Valor Padrão: -1

** O valor -1 representa falha do sensor

= Sigla Rotação Por Minuto 
RPM máxima

RPM média

RPM mínima

Sensores

Servos

Sinal de TV

Solicitação de estatística

Solicitação de Painel

reduzido

Speed

Arfagem

Tcharge

Tela
= RPM máxima obtida durante o vôo. $\mathrm{O}$ tipo da variável é igual a RPM

= Média aritmética das RPMs registradas pelo sensor durante o vôo. $\mathrm{O}$ tipo da variável é igual a RPM

= RPM mínima obtida durante o vôo. O tipo da variável é igual a RPM

$=$ Hardware que coleta dados físicos do meio ambiente

= Sinônimo de Bateria dos servos

$=$ Sinal de $\mathrm{TV}$ recebido pela placa de captura ou por um receptor de rádio

= Fluxo de controle que ativa a tela de estatística

$=$ Comando de trocar de painel

Tipo: Lógico

Valor Padrão: Falso

** Estado de verdade, indica painel alternativo

= Sinônimo de velocidade

= Indica a inclinação do bico da aeronave

Tipo: Inteiro de 16 bits

Representação: Intervalo [-1 a 359]

Valor Padrão: -1

** $O$ valor -1 indica falha do sensor

$=($ Servos + Comp_bord $)$

$=$ Interface grafica 
Temperatura do motor máxima

Temperatura do motor média

Temperatura do motor mínima
= Máxima temperatura do motor durante o vôo. $O$ tipo da variável é igual à Temperatura do motor

= Média das temperaturas do motor registrada durante um vôo. $\mathrm{O}$ tipo da variável é igual à Temperatura do motor

= Temperatura Mínima do motor durante o vôo. $O$ tipo da variável é igual à Temperatura do motor

Temperatura dos gases do = Indica a temperatura dos gases do escapamento que saem do escapamento escapamento do motor em graus Celsius.

Tipo: Inteiro de 16 bits

Representação: Intervalo [-1 a 500]

Valor Padrão: -1

** O valor -1 representa falha do sensor

Temperatura dos gases do Máxima temperatura dos gases do escapamento durante o vôo. $O$ escapamento máxima tipo da variável é igual à Temperatura dos gases do escapamento

Temperatura dos gases do Média das temperaturas dos gases do escapamento durante o vôo. $O$ escapamento média tipo da variável é igual à Temperatura dos gases do escapamento

Temperatura dos gases do = Mínima temperatura dos gases do escapamento durante o vôo. $\mathrm{O}$ escapamento mínima tipo da variável é igual à Temperatura dos gases do escapamento

Temperatura externa máxima

Temperatura extema média
= Máxima temperatura extema durante o vôo. O tipo da variável é igual à Temperatura extema

= Média das temperaturas externas registradas pelo sensor de temperatura durante o vôo. $O$ tipo da variável é igual à Temperatura externa 
Temperatura externa

mínima

Temperatura local

Temperature

Tempo

TGPS

Thoriz_artificial

Time

Tmotor

Tregisterlog

Ttemp
= Menor temperatura externa durante o vôo. O tipo da variável é igual a Temperatura externa

= Indica a temperatura do ambiente fora da aeronave em graus Celsius.

Tipo: Inteiro de 16 bits

Representação: Intervalo [-50 a 50]

Valor Padrão: -128

** A variável pode assumir o valor -128 para indicar falha do sensor

= Estrutura de dados que indica a temperatura externa à aeronave Tipo: Ttemp

** Ttemp está definido no DD

= Horário global. Informação obtida através do GPS

Tipo: Inteiro de 32 bits

Representação: Intervalo [ -1 a 863999]

Valor Padrão: -1

** O valor -1 indica falha do GPS

$=($ Alt + Lat + Longitude + Speed + Time $)$

$=($ Roll + Pitch $)$

$=$ Sinônimo de tempo

$=($ Egt + Temp + RPM + Fuel $)$

$=$ (Motor + Charge + Artificial_horizont + Temperature + Compass + Wind_speed + Altitude + GPS)

$=(\mathrm{Ext})$ 
Última atualização

Valor do sensor

Valor médio do sensor

Valores dos sensores defeituosos
= Dado que informa a quantidade de vezes que o sensor foi atualizado Tipo: Inteiro 32 bits

Representação: Contínua

= Valor enviado pelo sensor.

Tipo: Inteiro 32-bits

Representação: Contínua

Valor Padrão: 00
Valor máximo do sensor $=\{$ Velocidade do vento máxima $++R P M$ máxima + Altitude máxima ++ Temperatura externa máxima + Temperatura do motor máxima + Temperatura do motor mínima + Temperatura dos gases do escapamento máxima + Distância máxima +Velocidade máxima + Velocidade mínima + Altitude GPS máxima $\}$

= \{ Velocidade do vento média + RPM máxima + RPM mínima + RPM média + Altitude média + Temperatura média + Temperatura do motor média + Temperatura dos gases do escapamento média + Distância média + Velocidade média + Altitude GPS média

$=\{$ Dados dos Sensores $\}$

** Esta estrutura é igual a Dados dos sensores. Entretanto a estrutura é configurada com o valor padrão. A mesma é utilizada para testar a estrutura Dados dos sensores para verificar se os sensores estão funcionando

= A mesma estrutura do fluxo Dados transmitidos para modem da aeronave, porém sem o header e o check-sum. Contudo, inicializada com o valor padrão de cada sensor 
Velocidade

Velocidade do vento

Velocidade máxima

Velocidade média

Velocidade mínima

Velocidade do vento média

Velocidade do vento máxima

Velocidade do vento mínima

Visualização do log

Win_speed
$=$ Indica a velocidade da aeronave em $\mathrm{km} / \mathrm{h}$

Tipo: Inteiro de 16 bits

Representação: Intervalo [-1 a 300]

Valor Padrão: -1

** $O$ valor -1 representa falha do sensor

= Indica a velocidade do vento $\mathrm{em} \mathrm{km} / \mathrm{h}$

Tipo: Inteiro de 16 bits

Representação: intervalo [-1 a 300]

Valor Padrão: -1

** $O$ valor -1 indica falha do sensor

= Máxima velocidade registrada pelo GPS. O tipo dessa variável é igual à Velocidade.

= Média aritmética das velocidades registradas pelo GPS. O tipo dessa variável é igual à Velocidade.

= Mínima velocidade registrada pelo GPS. O tipo dessa variável é igual à Velocidade.

= Média aritmética das velocidades do vento registrada pelo sensor durante o vôo. $O$ tipo da variável é igual à velocidade do vento

$=$ Maior velocidade do vento obtida pelos sensores durante o vôo. $\mathrm{O}$ tipo da variável é igual à velocidade do vento

$=$ Menor velocidade do vento obtida pelos sensores durante o vôo. $\mathrm{O}$ tipo da variável é igual à velocidade do vento

$=\{$ Dados do Log $\}$

$=$ Sinônimo de velocidade do ar 


\section{Glossário}

Acelerômetro Instrumento que indica a aceleração em um dos três eixos.

Altímetro Instrumento utilizado para medir a altitude ao nível do mar.

AM Modulação de amplitude.

AUVS (Association for Unmanned Vehicle System) Associação para sistema de veículos aéreos não tripulados.

Baud Taxa de sinalização em bits por segundo.

CCD Charge Coupled Device. - Elemento detector de imagem.

CLIMB Instrumento que indica a razão de subida em pés por segundo.

DAAV (Dirigible Autonomous Aerial Vehicle) Veículo Aéreo autônomo dirigível.

DGPS (Differential Global Point System) Sistema que indica a posição em um ponto no globo terrestre através de satélites geo-estacionários e uma estação em terra.

Eixo longitudinal Vai do nariz até a cauda do avião.

Eixo transversal Atravessa o avião da ponta de uma asa à outra.

Eixo vertical Atravessa o avião perpendicular à sua fuselagem.

FM Modulação de freqüência.

Frame Conjunto de bits transmitido pela camada de enlace de dados.

Glow plug Elemento de ignição para iniciar o processo de combustão em aeronaves equipadas com motores glow. 
GPS

(Global Positioning System ) Sistema que indica a posição em um ponto no globo terrestre através de satélites geo-estacionários.

Guinada

IARC

LF

Link serial

LTA

MAV

MF

Mylar metalizado Tipo de filme plástico utilizado no envelope do dirigível.

NTSC

National Television Standards Committee.Sistema de cores para transmissão
de imagens de TV

Nylon metalizado Nylon utilizado na confecção do envelope do dirigível.

Pack radio É um modelo de comunicação digital por computador que utiliza o serviço
de radioamador.

PCMCIA

Pitch

PPM

R/C

RF
(Light-Than-Air) Mais leve que o Ar. Aplicado para dirigíveis que sobem em função do gás LTA.

(Micro Aerial Vehicle) Micro veículo aéreo. Aviões que possuem menos que $15 \mathrm{~cm}$.

(Medium Frequency) Freqüências Médias.
Personal Computer Memory Card International Association. Especifica uma interface para acoplamento de periféricos em computadores portáteis.

Movimento rotacional sobre o eixo transversal.

Pulse Position Modulation: modulação por posição de pulso. Rádio Controle. Técnica de pilotagem de veículo utilizando transmissores
de rádio para controle de um veículo.

Radio Frequency - freqüência de rádio. 
Rolagem Movimento rotacional sobre o eixo longitudinal.

RPH

(Remotely Piloted Helicopter) Helicóptero pilotado remotamente.

RPM

Rotações por minuto.

RPM

Rotações por minuto.

RPRV

(Remotely Piloted Research Vehicle) Veículo de pesquisa remotamente pilotado. Utilizado para pesquisa de novos conceitos aerodinâmicos.

RPV

(Remotely Piloted Vehicle) Veículo pilotado remotamente. Semelhante aos utilizados pelos R/C.

$\mathbf{R x}$

Recepção.

Spinner

carenagem cônica colocada no eixo do motor do avião.

SPV

(Self Piloted Vehicle) Veículo auto-pilotado.

Arfagem Movimento rotacional sobre o eixo transversal.

Target drones Alvos não tripulados.

$\mathbf{T x}$

Transmissão.

UAV

(Unoccupied Air Vehicle) Veículo aéreo não ocupado.

UHF

(Ultra High Frequency) Freqüências Ultra Altas.

UMA

(Unmanned Aircraft) Aeronave não tripulada.

UTA

(Unmanned Tactical Aircraft) Avião Tático não tripulado.

UVS

(Unmanned Vehicle System) Sistema de veículo não tripulado.

VLF

(Very Low Frequency) Frequiências muito baixas. 